جامعترالموصل كليتالآثار

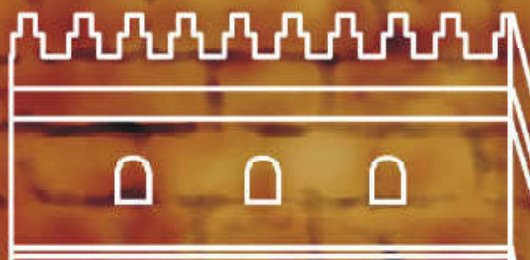
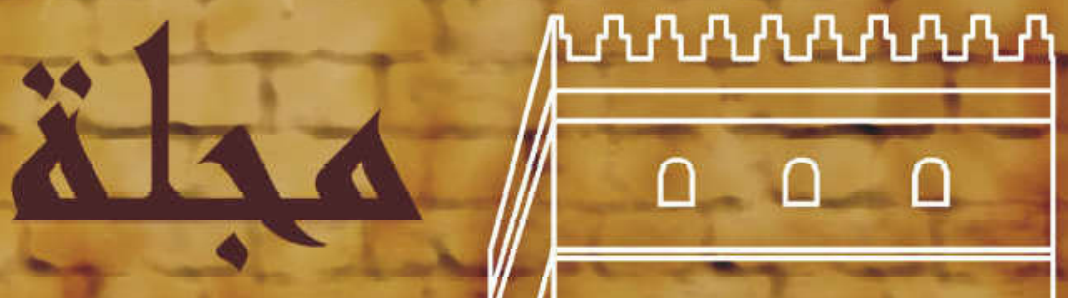

وزارة التعليمالكالي

والبحث العلمي

ISSN $2304-103 X$

$\| \vec{R}=\square]$

Academic Scientific Journals

$\frac{3}{3}$

No

\%.

0

กิ

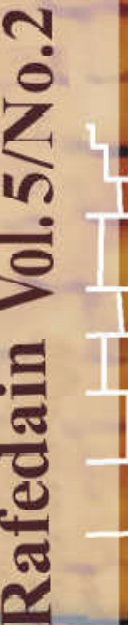

3

$T$
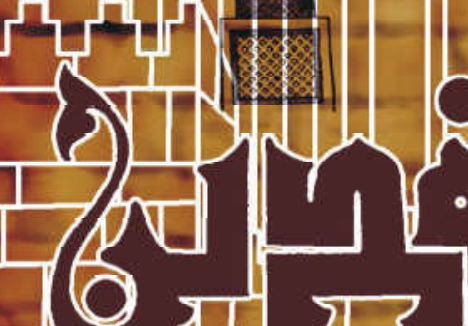

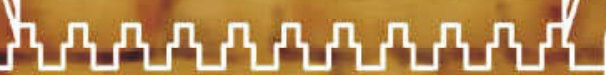
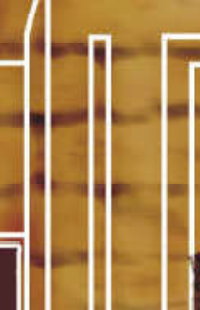

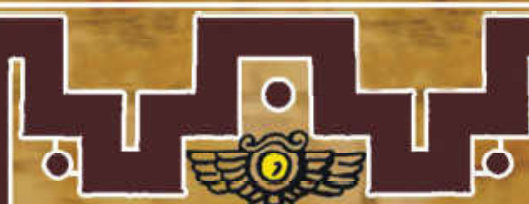
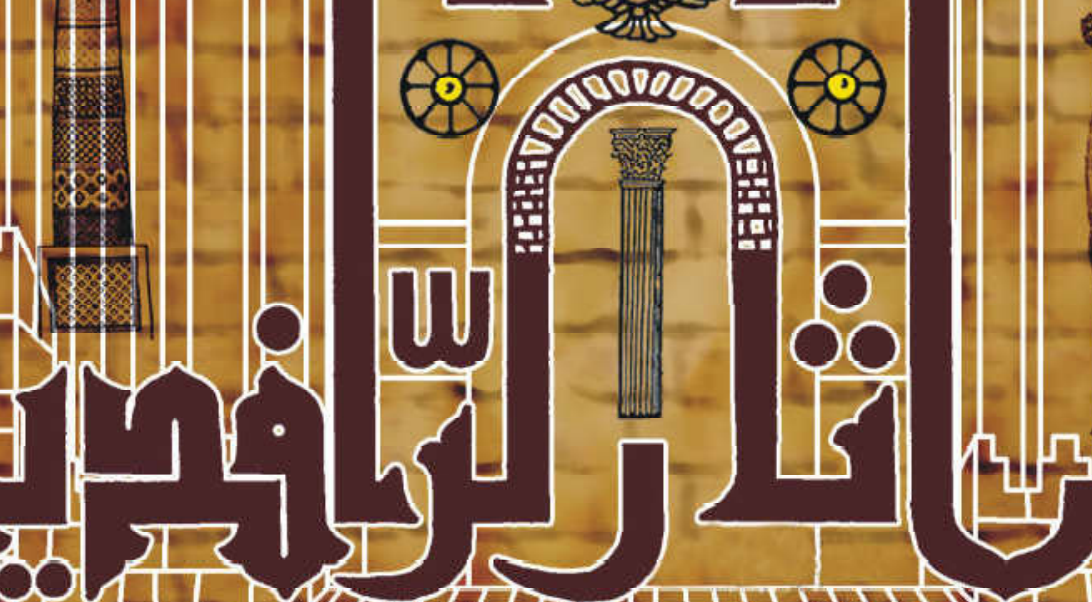

यदा

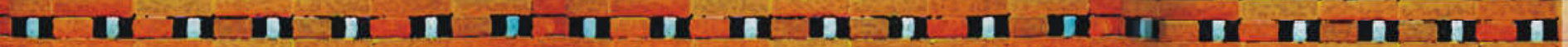

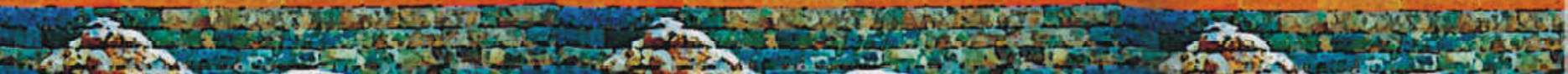

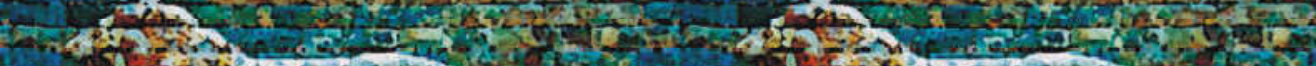

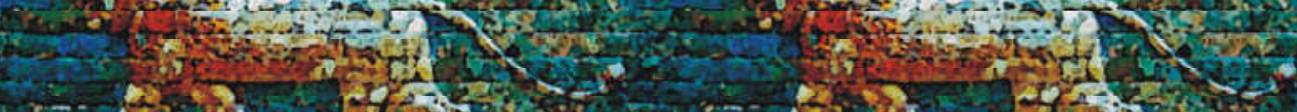

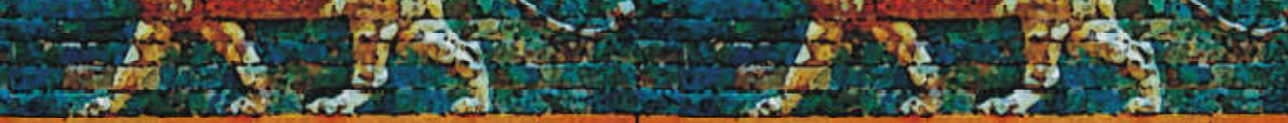

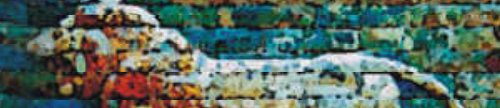

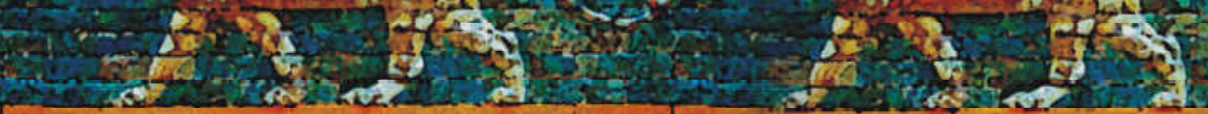

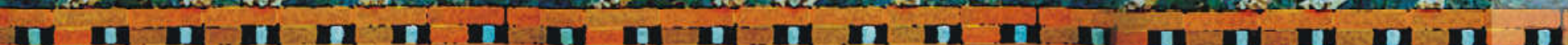

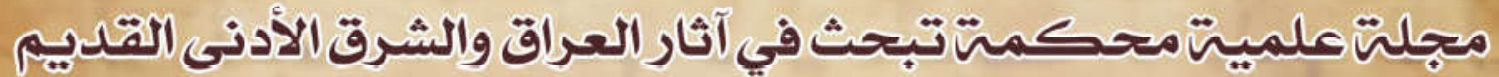

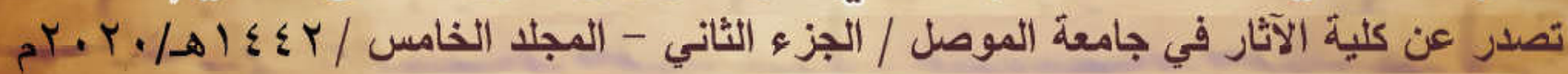



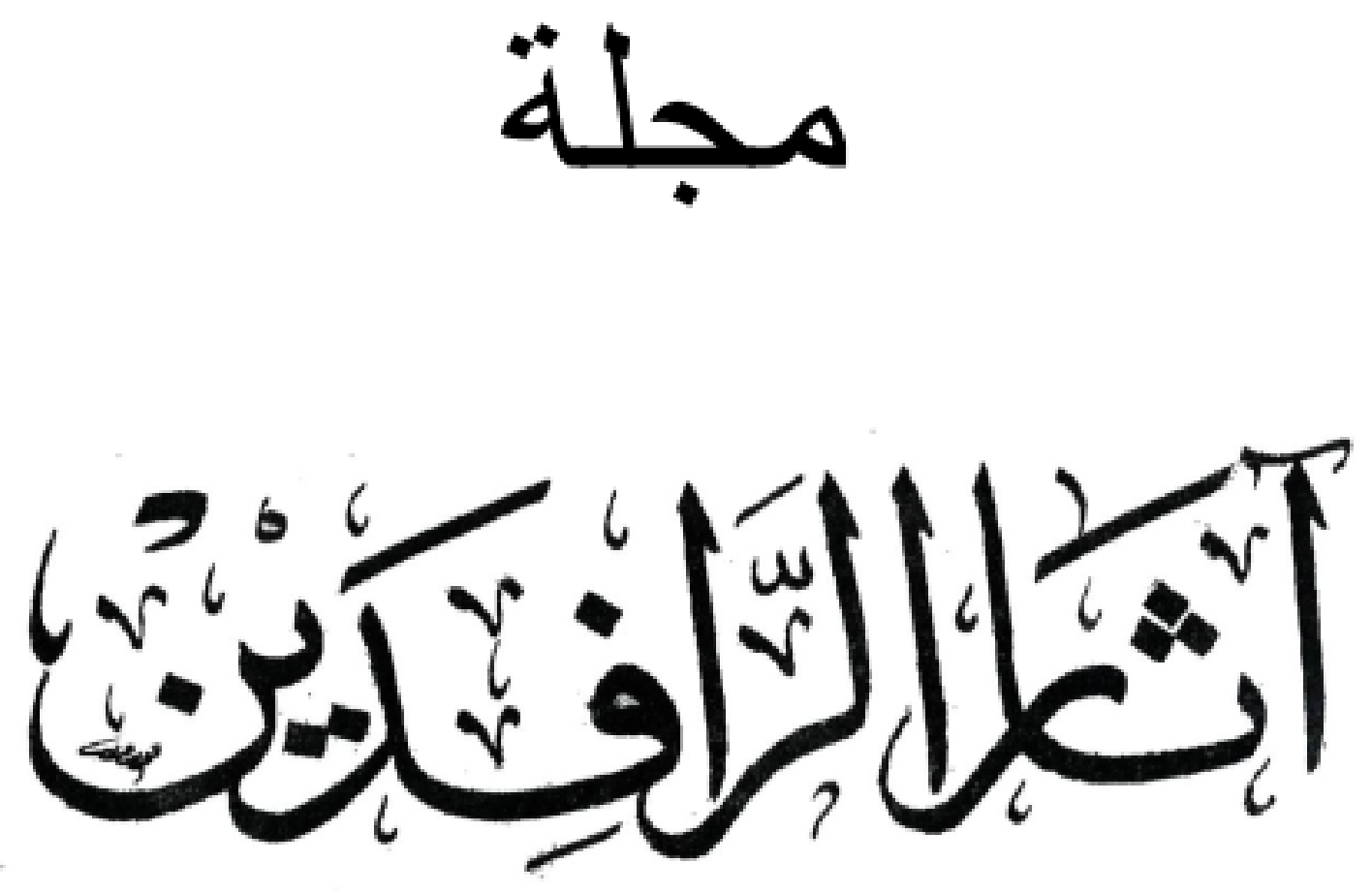

هبلة علمية هحكمة تبحث في آثار العراق و الشرق الأدنى القديم تصدر عن كلية الآثار في جاهعة الموصل

E-Mail: uom.atharalrafedain@gmail.com البريد الاكتروني

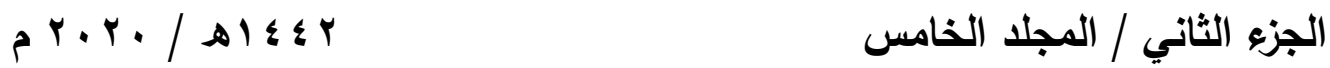

$$
\begin{aligned}
& \text { رقم الايداع في دار الكتب والوثائق ببغداد }
\end{aligned}
$$

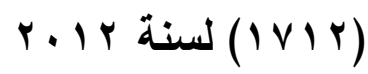





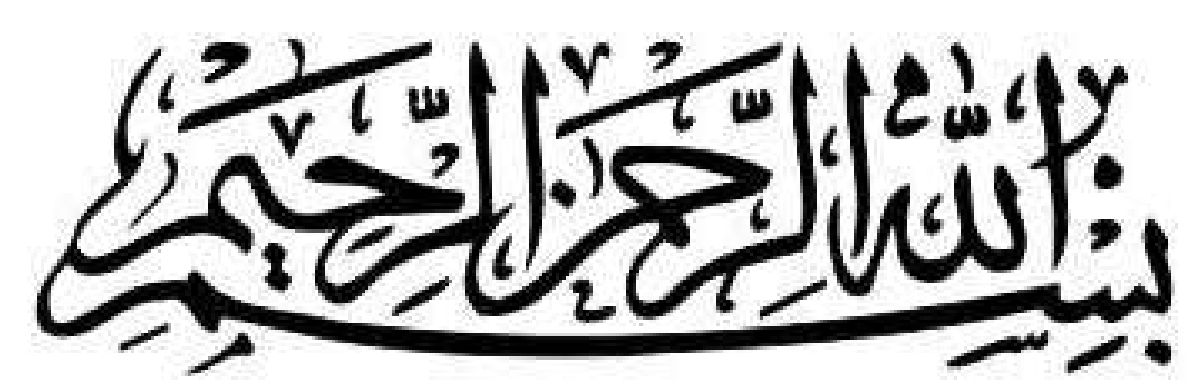





\section{هيأة التحرير}

أ. خالد سالم اسماعيل

رئيس التحرير

أ.ه. حسنين حيدر عبد الواحد

الاعضاs

أ.د. اليزابيث ستون

أ.د. ادل هايد اوتو

أ.د. والتز سلابيركر

أ.د. نيكولو هاركيتي

أ.د. هديب حياوي عبد الكريم

أ.د. جواد هطر الموسوي

أ.د. رفاه جاسم حهادي

أ.د. عادل هاشمم علي

أ.م.د. ياسمين عبد الكريم همهد علي اليمي

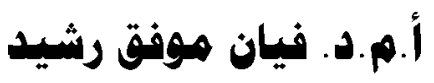

أ.م.د. هاني عبد الغني عبد الله 


$$
\begin{aligned}
& \text { هقوم اللغة العربية }
\end{aligned}
$$

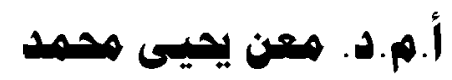

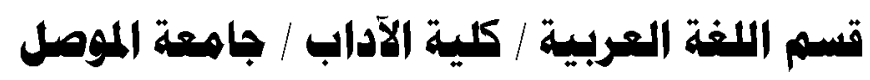

$$
\begin{aligned}
& \text { هقوم اللغة الانكايزية } \\
& \text { م.م. عمار احمد هممود } \\
& \text { قسم الترجمة / كلية الآداب / جامعة الموصل }
\end{aligned}
$$

$$
\text { د. تصميم الغلاف البميلي }
$$




\section{قواعد النشر في هجلة آثار الرافدين}

1- 1قبل المجلة البحوث العلمبة التي تقع في تخصصات:

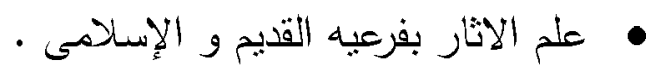

اللغات القديمة بلهجاتها و الدراسات المقارنة.

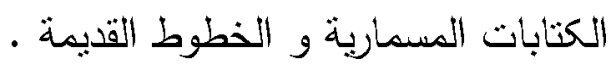

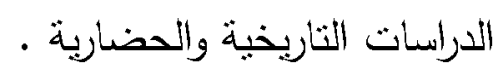

$$
\begin{aligned}
& \text { الجيولوجيا الاثارية . } \\
& \text { تقنيات المسح الاثارى . }
\end{aligned}
$$

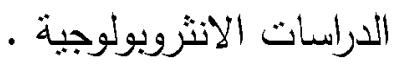

$$
\begin{aligned}
& \text { • الصيانة والتنرميج . }
\end{aligned}
$$

r- تقدم البحوث الى المجلة باللغتين العربية أو الانكليزبة .

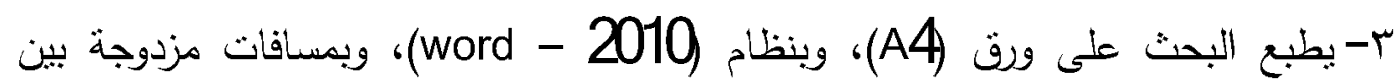
الاسطر، وبخط Simplified Arabic للغة العربية، و Times New Roman للغة

$$
\text { الانكليزبة، وبيلم على قرص ليزري (CD) )، وبنسختين ورقيتنين. }
$$

ع-بطبع عنوان البحث في وسط الصفحة بليه اسم الباحث ودرجته العلمبة ومكان عمله

$$
\text { كاملا والبربد الاككتروني (e-mail). }
$$

ه- يجب ان يحتوبي البحث ملخصا باللغتين العربية والانكليزية على ان لا تزبد عن (· (1)

$$
\text { كلمة. }
$$

؟-يحتوب ملخص البحث بالإنكليزية على عنوان البحث واسم الباحث ودرجته العلمية

$$
\text { ومكان عمله كاملا والبربد الالكتروني له. }
$$

V- تضمين البحث كلمات مفتاحبة تتعلق بعنوان البحث ومضمونه.

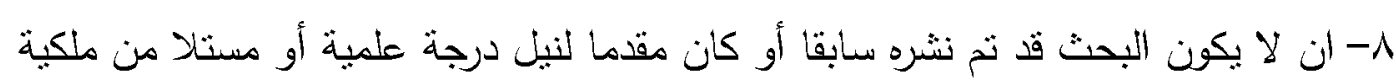

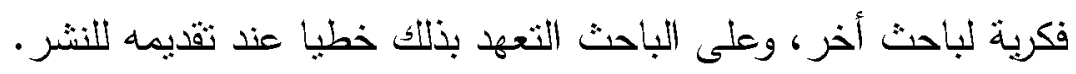

$$
\text { 9- بلتزم الباحث باتباع الانس العلمية السليمة في بحثن. }
$$

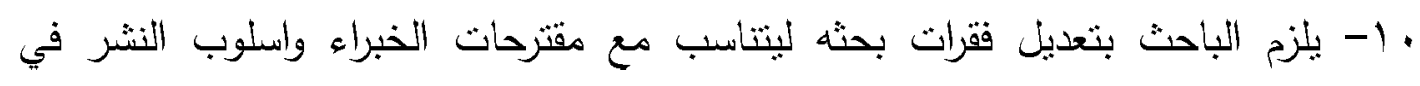


11-1 لا تتجاوز عدد صفحات البحث عن (Y0)، صفحة وفي حال نجاوز العدد المطلوب يتكفل الباحث بدفع مبلغا اضافيا من كل صفحة اضافية.

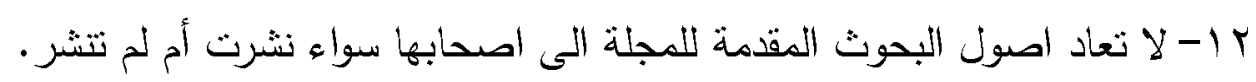
با - نزقم الجداول والاثكال على الثوالي وبحسب ورودها في البحث، وتزود بعناوين، وتقدم بأوراق منفصلة وتقدم المخططات بالحبر الاسود والصور نكون عالبة الاقة. ع ا-نكتب ارقام الهوامش بين فوسين وترد منسلسلة في نهابة البحث.

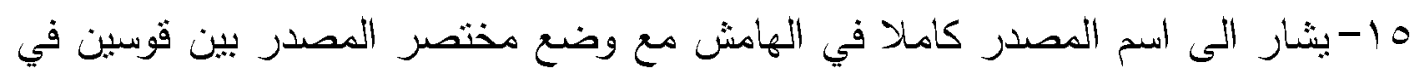
نهاية الهامش.

17 - 17

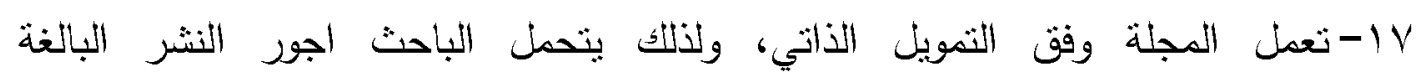

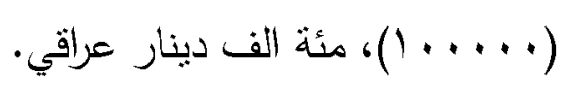

11- بزود كل باحث بمستل من بحثه، أما نسخة المجلة كاملة فتطلب من سكرتاربة المجلة

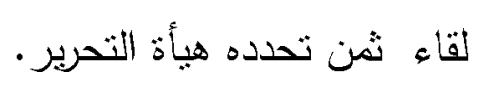
19 - نرسل البحوث على البربد الالكتروني للمجلة: uom.atharalrafedain@gmail.com 
ثبت الحتهويات

\begin{tabular}{|c|c|c|}
\hline العنوان & اسم الباحث & الصفحة \\
\hline توطئة & أ. خالا سالم اسماعيل & 1 \\
\hline 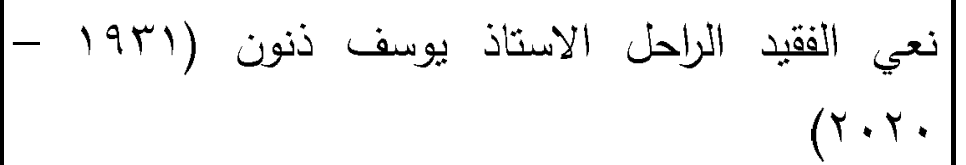 & |أ.د. جابر خليل أبراهيم & T-4 \\
\hline |محفيغ أُكدية في نصّ مسماريّ جديد من عصر أَور الثالثة & |أ. خالد سالم اسماعيل & $1 T-V$ \\
\hline مرضُ الصرع في المصادر المسمارية في بلاد الرافدين & أ.د. نواله احمد المتولي & $r \wedge-1\rangle$ \\
\hline قثشلة مه زنى (دراسة ميدانية) & أ. أ.د. خ.د. خلف فارس الطراونة & $7 \cdot-4 q$ \\
\hline |العناصر التكوينية لعمارة البيت التراثي في شمالي العراق & أ.م.د. عبد الله خورشيد قادر & $9 \leq-71$ \\
\hline 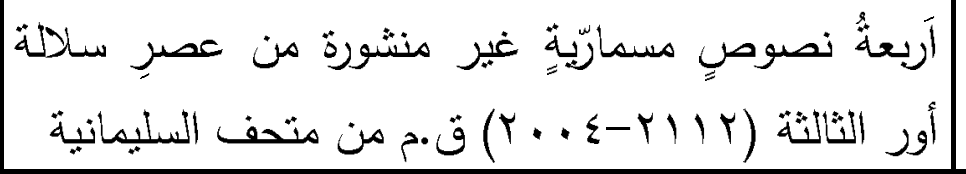 & |أ.م.د. ناري خلين كامل & $11 r-90$ \\
\hline 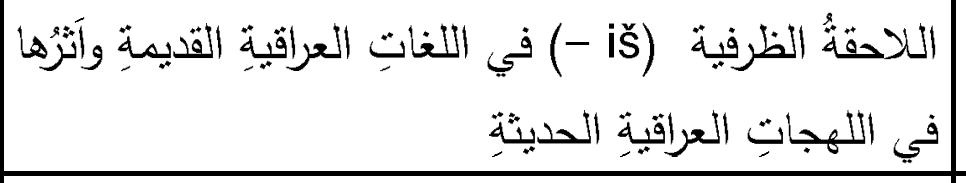 & |أ. م. عثمان غانم محمد & $m \cdot-11 \pi$ \\
\hline |نتحلّق بالحيوانات مسماريةٌ غيرُ منشورٍٍ من عصر أور الثالثة & م.د. وفاء هادي زويد & $10 \leq-1 \pi$ \\
\hline | دراسة نتاتُ محاريب مساجد الموصل في العصر العثمانيّ & |م. د. هيثم قاسم محمد & $111 \leqslant-100$ \\
\hline الحيوانات على مثاهد فنون العصر السومري الحديث & م. غسان مردان حجي & $r \cdot r-110$ \\
\hline | من الحفارين الثرقاطيين: صالح الأحمد الحميضة وشقيقة & |م. غسان صالح الحميضة & $r+r-r \cdot r$ \\
\hline \multicolumn{3}{|c|}{ القسم الانكليزي: } \\
\hline |الأستشعار عن بعد في علم الاثار : ملخص استعراض & | م.م. محمد حمه غتريب محمد & $r \cdot-r$ \\
\hline
\end{tabular}





\section{صالح الأحمد الحميضة وشقيقةُ محمد}

\section{خدما المسيرة الاثارية في العرلق}

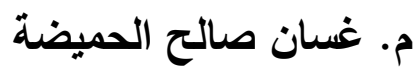

كلية الاثار - جامعة سامراء

ghassan1984g@gmail.com

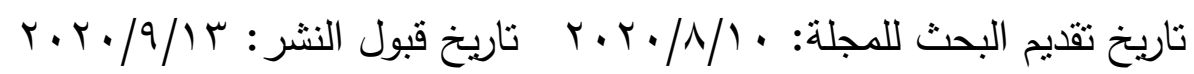

ملخص البحث :

يتتاول البحث السيرة الاثارية لاثثين من أمهر الفنيين والحفارين الثرقاطيين وأبرزهم هما

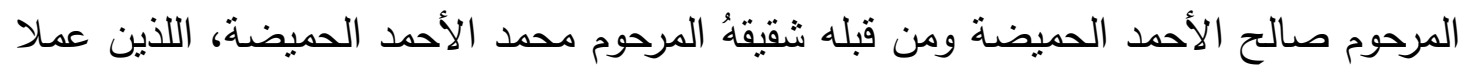
في تتقبب وصيانة الآثار العراقية منذ الصبا، وتوفيا وعليهما تراب العمل. وسنبين في البحث

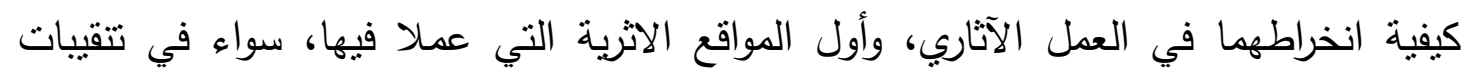

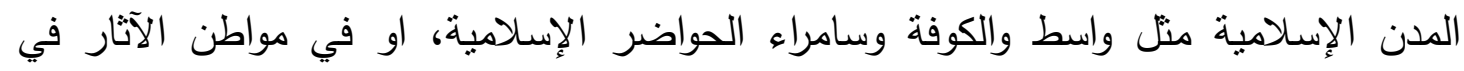

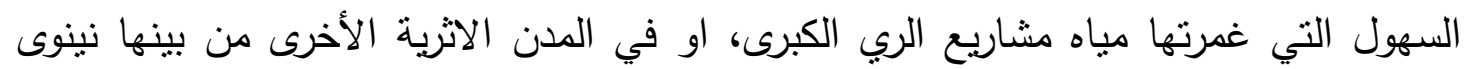

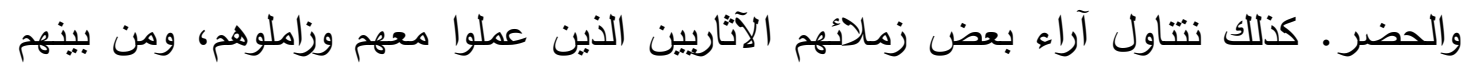

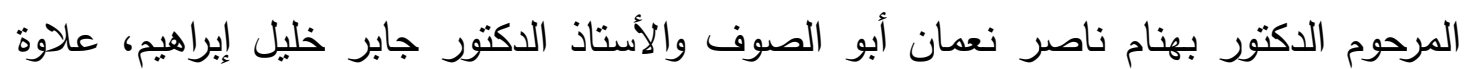

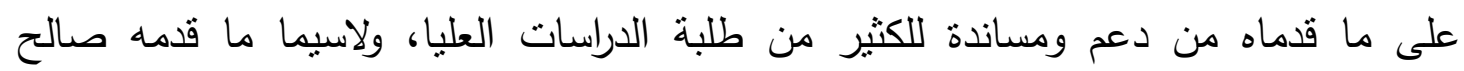

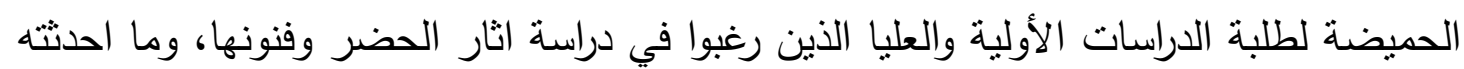

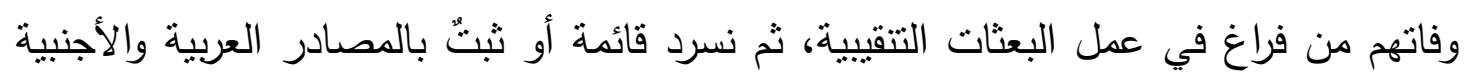

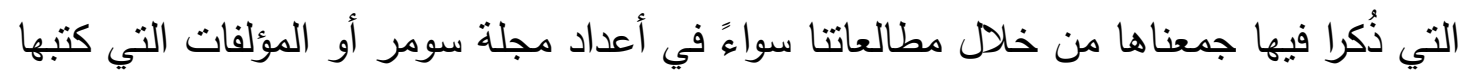

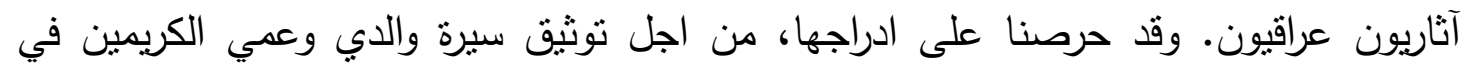

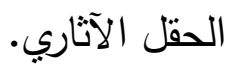
الكلمات المفتاحية: الحفارين الثرقاطيين، صالح، محمد، بهنام، جابر ، الحفريات أو التتقيات، مشاريع الري الكبرى، الحضر ل مئهن 


\title{
From the Sharqati Excavators : \\ Salih Ahmed Al-Hamedha and his brother Mohammad \\ Served the archeological Excavations in Iraq \\ Lecturer. Ghassan Salih Al-Hamedha \\ College of Archeology - University of Samarra \\ ghassan1984g@gmail.com
}

\begin{abstract}
:
The research deals with the archeological biography of two of the most skilled technicians and Al-Sharqati excavators, the most prominent of them are the late Salih Ahmed Al-Hamedha and before him his brother Mohammad Ahmed Al-Hamedha, who worked in the excavation and maintenance of Iraqi antiquities since they were young children and died and on them the dust of work, and we will show in the research how they are involved in archaeological work, and the first sites The archeology in which they worked, whether in excavations of Islamic cities such as Wasit, Kufa, and Samarra, Islamic cities, or in the plains flooded by major irrigation projects, or in other archeological cities including Nineveh and Hatra, as well as discussing the opinion of some of their fellow archaeologists who worked with them and their fellows, and among them The late Dr. Behnam Abu al-Soof, and Professor Dr. Jaber Khalil Ibrahim, in addition to their support and assistance to many graduate students, especially what Salih Al-Hamedha provided to students of primary and higher studies who wished to study the effects of urban art and its arts, and the void created by their death in the work of excavation missions Then we list a list of Arab and foreign sources that we collected through our readings, whether in Sumer magazine or the books written by Iraqi archaeologists. We have been keen to include it, in order to document the biography of my generous father and uncle in the archaeological field.
\end{abstract}

key words: From the Sharqati excavators, Salih, Mohammad, Behnam, Jaber, Excavations, major irrigation projects, Hatra .

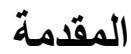

فقدت الهيأة العامة للآثار والتراث خلال سنوات القرن العشرين الكثبر من الفضلاء من

الأسرة الاثارية، ومنهم مجموعة طيبة من الفنيين والحفارين الثرقاطيين المهرة ومن أبرزهم

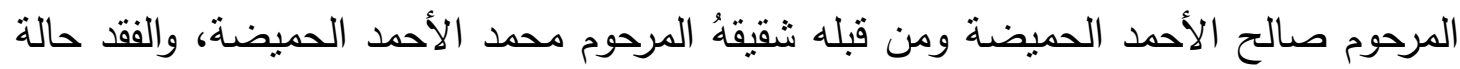

مؤلمة، والفراق هاجس مرعب يبقى كامناً في ذهن الانسان وان كان تقسيره هو انتقال من حياة

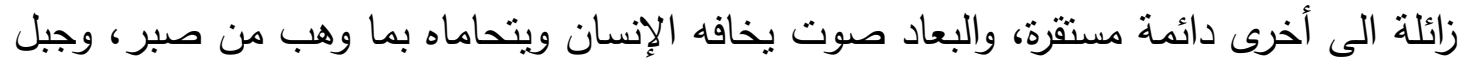


عليه من جلد، وتعود عليه من عادات. ولكننا نؤمن أَنّ هذه الدنيا ليست بدار قرار، وان ناموس فئس الحياة وطبيعة الأقدار وإرادة الله هي التي تحكم حياة البشر . فالناس لا ينفكون من المصائب، ومن لم يثكل أخاه، ثكله أخوه. والموت حق تساوى فيه الضعيف والقوي(')، وفي قوله تعالى (كُلٌ

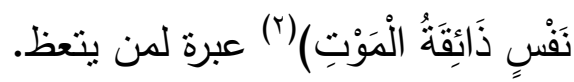
قبل خوضنا في سيرة هاتين القامتين الكبيرتين من الشرقاطيين(r)، بدءاً نود ان نبين انه كانت نيتتا ان نتتاول سيرة مفصلة ومكتملة لعدد أكبر من الرعيل الأول والثاني وحتى الثالث من هن الحفارين الثرقاطيين في بحث بهيأة مجلد او مجلدين وباشرنا بالفعل إلا أن قلّة المعلومات وعدم ضبطها والتأكد من مصداقيتها ولالتزامنا الجاد والتام بالأمانة العلمية التي تتطلبها الكتابة والخوض في موضوع منل هذا يتتاول فيه سيرة الحفارين الثرقاطيين وامكانياتهم العالية في مجال المسح والتتقيب والصيانة وإدارة ومراقبة العمل، ولاسيما ما يتطلبهُ منا موضوع البحث من مراجعة كل الوثائق والاضابير التي تعنى بتتقيب وصبانة المواقع الاثرية وأعضاء بعثاتها وأسماء العمال العاملين تحت إدارتها منذ السنوات الأولى لتأسيس مديرية الآثار العامة والاطلاع عليها ومعرفة البعثات المسحية والتتقيبية سواء في مشاريع الري الكبرى (التتقيات الانقاذية) او أعمال التتقيب الأخرى ومساهمة الحفارين الثرقاطيين فيها واوامر تعيينهم ومباشراتهم ومستوى مهارتهم ومهنيتهم

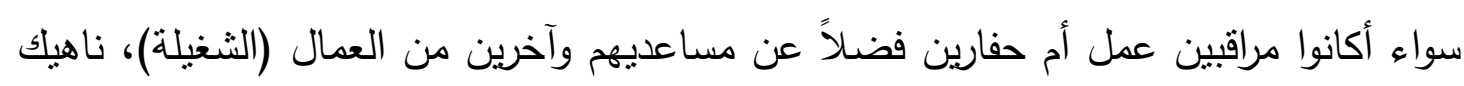
عن عدم اهتمام أو ابداء التعاون الكافي من اغلب ذوبهم من أبنائهم واحفادهم في تقديم معلومات وافية ودقيقة او صور عنهم ولا اعرف ان كان السبب هو جهلهم في هذا الامر ام انهم

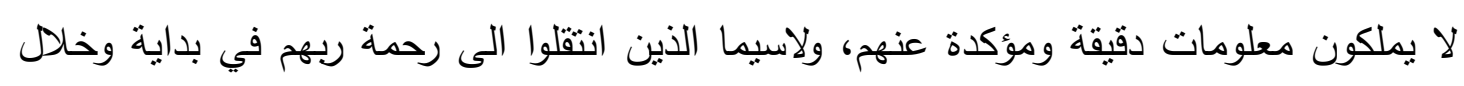

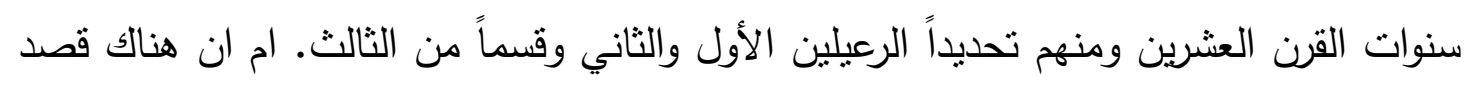
آخر نجهله، مدا اضطرنا مُكرهين الى تأجيل العمل في هذا المشروع لحين توفر الوثائق والبيانات التي تتيح لنا الخوض في هذا الموضوع، وسنكون مطمئنين من دقة المعلومات وصدقها التي نقدما للقارئ وفائدتها والتي تحفظ لكل منقب حقه، ونكون بذلك قد قدمنا شيئاً متواضعاً اكراماً وعرفاناً واجلالاً لهذه النخبة الخيرة والامينة من الحفارين، التي عرّفت الثرقاط واشتهرت بجديتهم في العمل وطيتهم وحسن معشرهم وعرفوا في كتب التاريخ بأسمها (الحفارين الشرقاطبين).

ومن الواجب علينا ان نقدم نبذه عن الحفارين الثرقاطيين. فقد كان في ريف بلدة الثرقاط بساحليها الأيسر والأيمن من نهر دجلة خبرة الحفر في الاثار وغيرها من الخبرات والمهن المختلفة، لم يكن لها نظير في أماكن أخرى، فمنذ منتصف القرن التاسع عشر، حين بأشرت أولى بدايات التتقيب تجرى في ارض الرافدين. اختار علماء الاثار الأجانب من الشرقاطيين، 
عمالاً مهرة في الحفريات الاثرية يكثفون عن أبنية مطمورة في ارض آنثور، فصار الحفر والتتقيب، حرفة رئيسة لهم، وولعاً وشوقاً، انتقلت الى أبنائهم واحفادهم من بعدهم، وانتشرت انباؤهم في الخارج، وسجلت ابداعاتهم في الكتب والوثائق والصور والخرائط، حتى ان من بين هؤلاء الثرقاطيين من اتقن الحرفة الاثاربة، وتحديد طبقات السكنى، فتجاوز في اتقانه، مهندس الاثار الأجنبي والباحث الاثاري الأجنبي والمساح والمصور وراسم الخرائط الأجنبي، لان الشرقاطيين لكثرة قراءاتهم الأرض، أدركوا أنهم يحفرون في تاربخ أجدادهم القدماء، وعلى وجه الاهي التحديد هؤلاء الذين كانوا قد أقاموا في مدينة آثور الاثرية (عاصمة اول مملكة للآشوربين) القريبة من مدينتهم (شرقاط)، أبهى عواصم الدنيا، فأتقنوا التاريخ بالممارسة(ع). حتى انهم تمكنوا في مدة زمنية قصيرة من الالمام على معظم فنون التتقيب العلمي وأساليبه والتدرب على أسلوب من تشخيص الرقم الطينية وفرزها وكيفية رفعها دن معاثرها، بإتقان ومعرفة جدران اللبن وتحديدها وتقريد اللبنة الواحدة (تمييزها وتحديد محيطها) ومعرفة حجمها والمادة الرابطة. واكتشاف اللقى الاثرية الصغيرة والمحافظة عليها، وهكذا اعتمدت المدرسة العراقية للتنقيب على مهارتهم في تتقيب المواقع الاثرية القديمة منها والاسلامية وغدا وجود عدد من الثرقاطيين الذين بدأ يطلق عليهم اسم "العمال الفنيين او الحفارين الفنيين“، امراً ضرورياً في عمل كل بعثة تتقيب اجنبية كانت أَو عراقية. وبرز عدد من بين هؤلاء العمال الفنيين واثتنهروا بأساليبهم الفنية الدقيقة في التتقيب والاعمال الهندسية من مسح للمواقع ورسم خرائط كنتورية ومخططات الأبنية المكنتفة الى غير ذلك وكانت أساليهه في التتقيب والاعمال الهنسية تقارب حتى الأساليب الأجنبية(0). لقد اصبح عمال الاثار الثرقاطيين العلامة المميزة للعمل الاثاري في العراق سواء مع البعثات الاثارية الأجنبية أَّ مع البعثات العراقية، في مواقع التتقيات وكذلك مواقع الصيانة الاثرية، وأصبحت مشاركتهم في العمل الاثاري ضرورية من الناحية الفنية من خلال اعمال التتقيب والكثف عن الطبقات الاثرية والمحافظة على اللقى الاثربة، وكذلك من الناحية الإدارية التي تتطلب مراقبة دقيقة وشاملة للعمال في الموقع الاثري، وعندما كان يصدر امر اداري من دائرة الاثار والتراث لتشكيل هيأة اثارية للتنقيب في موقع معين، يعمد رئيس الهيأة الى البحث عن (المنقب او الحفار الثرقاطي) الذي يعتمد عليه في أعمال التتقيب وإدارة الموقع ومراقبة العمال، وكذلك الامر مع البعثة الأجنبية التي تبحث عن الثرقاطيين لتضمهم الى عملها في الموقع. هذه باختصار قصة شهرة العمال الثرقاطيين في عمليات التتقيب في المواقع الاثرية العراقية، وانتقلت خبرتهم كما أسلفنا الى أبنائهم وأحفادهم من بعدهم. 


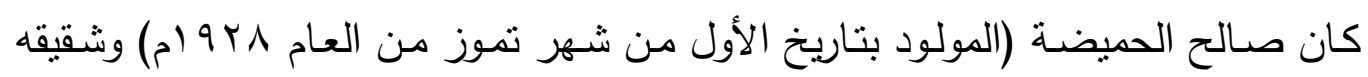

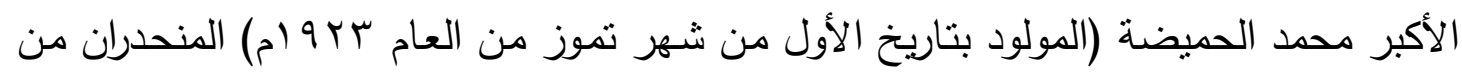

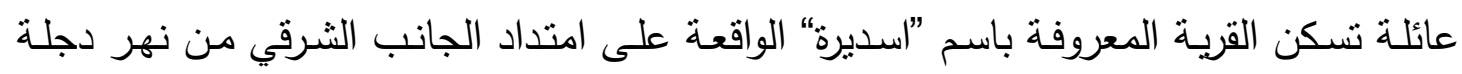

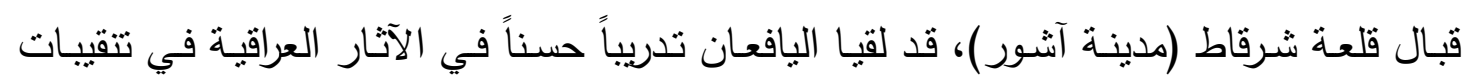

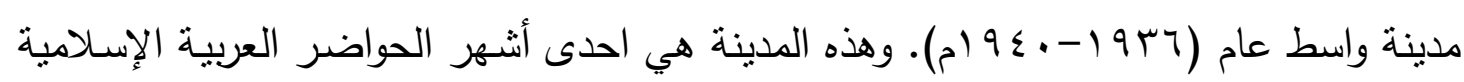

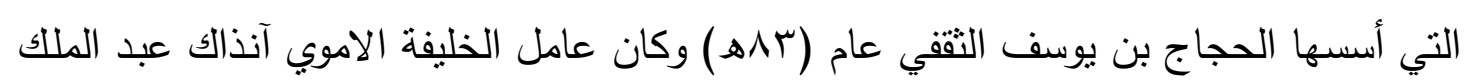

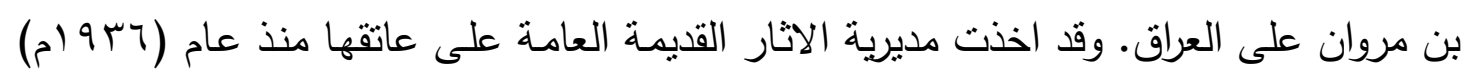

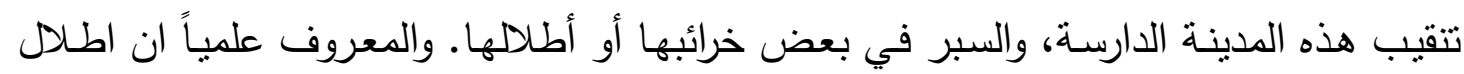

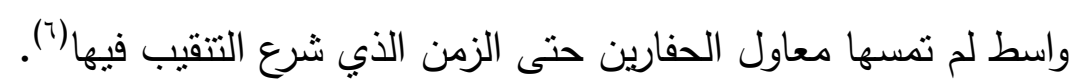

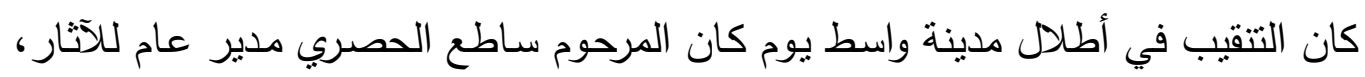

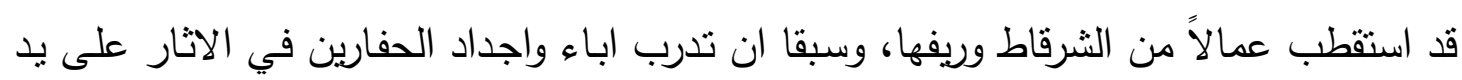

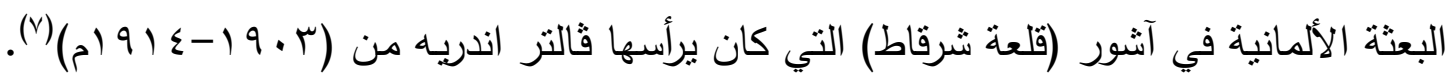

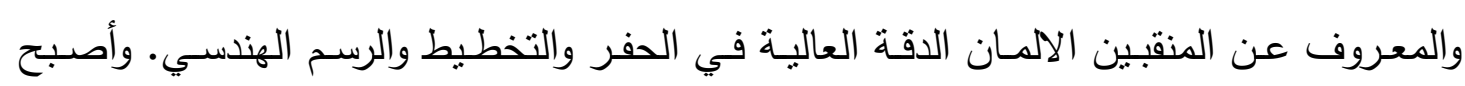

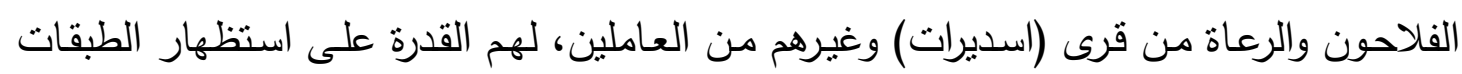

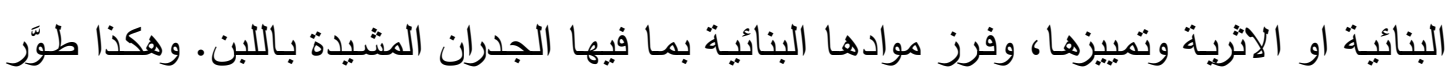

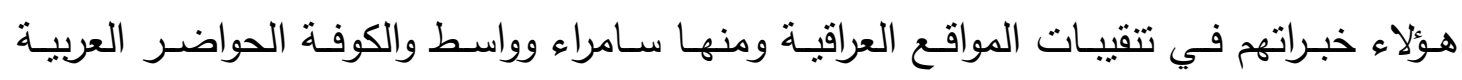
الإسلامية، وغيرها من المواقع الاثرية المبثوثة في السهول التي شملتها أو غمرتها مياه أحواض التهات

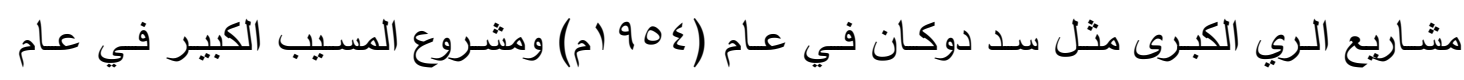

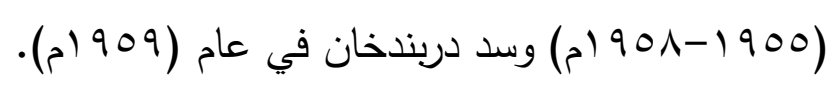

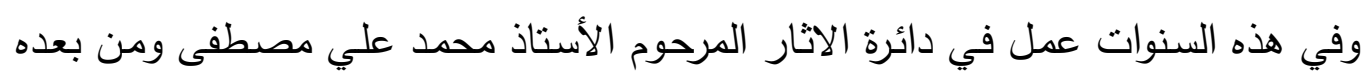

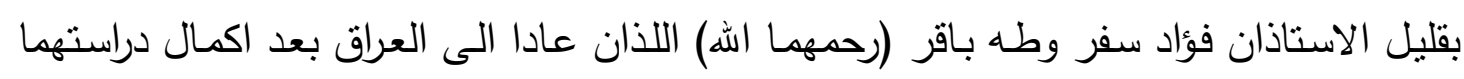

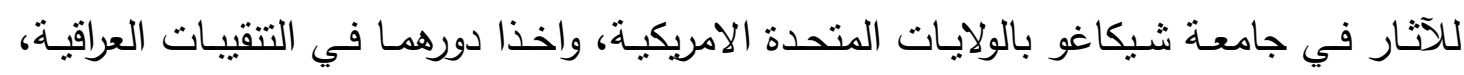

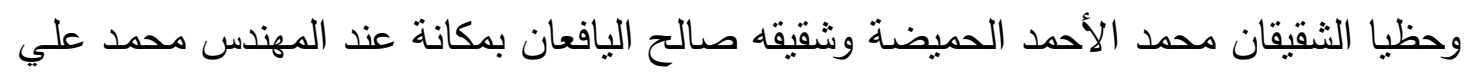

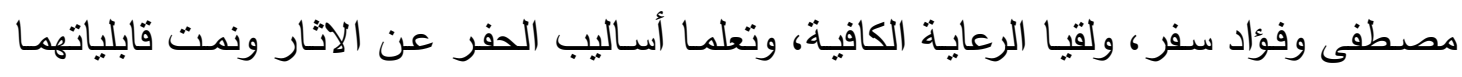

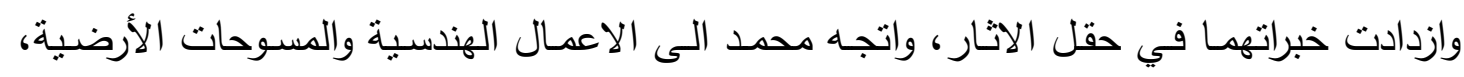

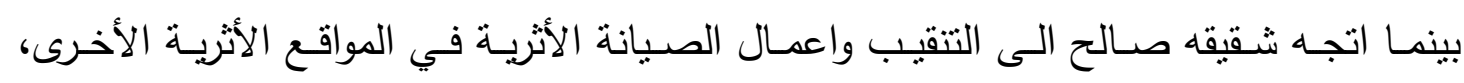

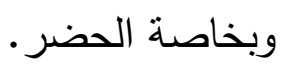




\section{أولاً : محمد الأحمد الحميضة :}

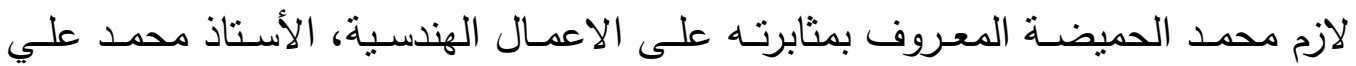
مصطفى الذي أعطساه التدريب الكافي على الأعمـال الهندسية مـن مسـح وتخطبط واستخدام الأجهزة والمعدات الهندسية على الرغم مـن انـه أُمسي، فأتقن وأجـاد في مسـح المبـاني الاثربـة المستظهرة وفي اسوار المدن القديمة المكتشفة ومنها نينوى. حتى ان مسوحاته قد طابقت مـا أنجزه الضابط البريطاني فيلكس جونز في اطله نينوى واسوارها عام (Y؟1 (م)، المعروف بدقته في الأعمال الطوبوغرافية.

وبمرور السنوات وتعاقب مواسم التتقيب حفظ محمد الحميضة أسماء ومصطلحات هندسية لا يعرفها ولا يرددها إلا المهندسون والمساحون، وتعلم كيفية القيام بالأعمال الهندسية والمسحية حتى أثقنها فاستحق لقباً حرص رفاقه وجماعته على مناداتهِ به ألا وهو "المهندس"، وبالفعل كان

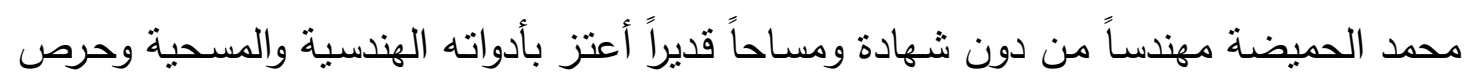
على ما أنجزه من خرائط ورسوم ومخططات وصانها من الأتربة والرياح والأمطار والقوارض في لي مبادين التقبيب.

كان محمد دقيقاً في أعماله يقضي وقتاً طويلاً للتأكد من جزء من الملمتر إذا ظهر عنده خطأ في مقياس الرسم. وقد يستغرب القارئ إذا عرف أن ذلك العامل درب طلاب قسم الآثار من كلية الآداب في جامعة بغداد، على نصب طبلة المسح الهندسية واستخدامها، واستعمال الأدوات الهندسية الأخرى وشرح لهم مبادئ العمل الهندسي في الآثار وكيفية نقل بقايا الجدران والأسس والمباني من الأرض على ورق الرسم بمقاسات معينة وغيرها، وكانت البداية في موقع الحضر والمواقع الأخرى الممتدة مع مشروع المسيب الكبير، الواقع بين بلدتي المسيب والصسيرة(^)، مع الع الدفعة الأولى من طلبة فرع الآثار العام (90r (م) وهو الأمي الذي لا يجيد القراءة والكتابة عدا لهاب ما حفظه من أرقام على مسطرة القياس وجهاز قياس الارتفاعات(9). وواصل محمد الحميضة هذا العمل بكل همة ونشاط وحينما كان بنظر إلى لوحة التخطيط وبيده شـريط القياس وقلم الرصـاص، يخطط مـا كثف عنه التنقيب مـن جدران هثـة في تل

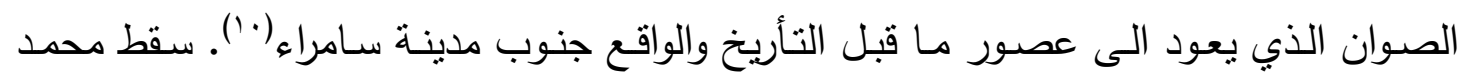
الحميضة على الأرض فجأة ومات بالسكتة القلبية في صباح يوم الثلاثاء (الثامن عشر من شهر تشرين الثاني من عام 999 (م)، وهو في العقد الرابع من عمره، وبموته بقي هذا الميدان شـاغراً عانى منه المنقبون الكثير - ع ويذكر المرحوم الدكتور بهنام ناصر نعمان أبو الصوف ان للعمال الثرقاطيين فضل عليه منذ بداية دخوله في اعمال المسح والتتقيب الاثاري في صيف (907 (م)، اذ يذكر (كانت عمليات التقيب في تل باسموسيان (وهو تل واقع في سهل رانية بمحافظة السليمانية)('(') 
تجرية (أبو الصوف) الأولى في التنقيب بعد تخرجه من الكلية، الا انها كاتت تجرية غنية

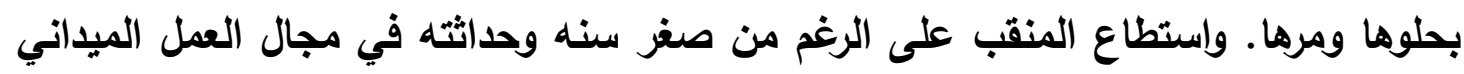

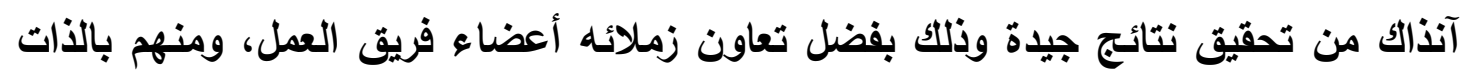

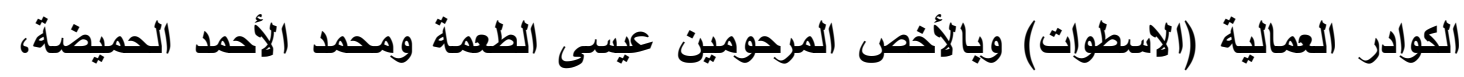
ويقية الاسطوات الثرقاطيين الذين منحوه ويسخاء خبرتهم وتجريتهم الطويلة في اعمال التنقيب عن الاثار وذلك للهفته على التعلم منهم والجلوس اليهم في خنادق التنقيب طويلاً والاستماع بجد الى شروحاتهم وملاحظاتهم)(r').

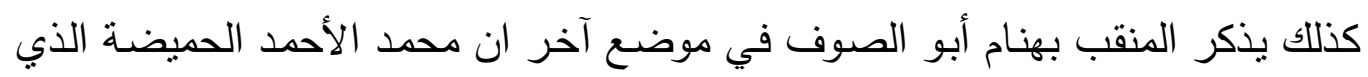

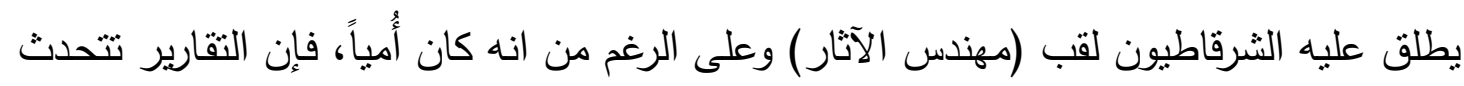

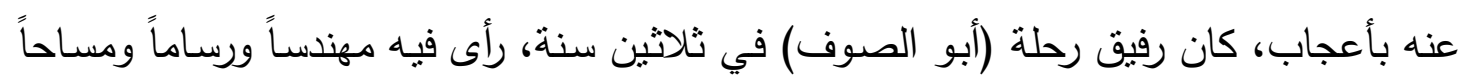

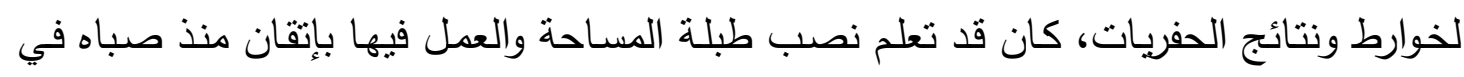

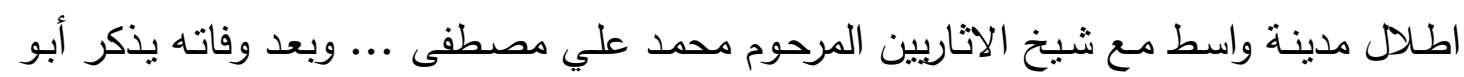

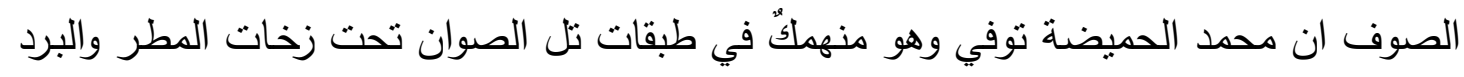

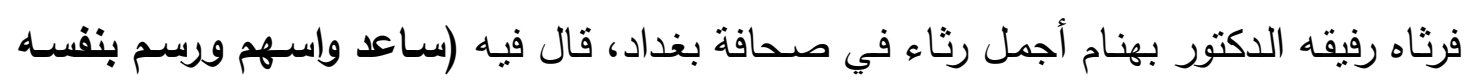

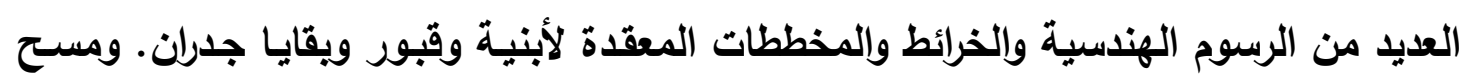

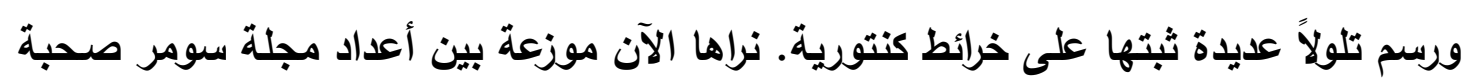

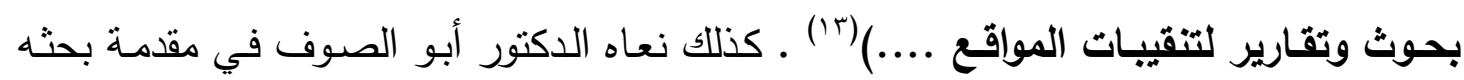

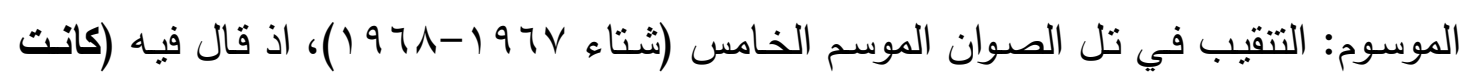

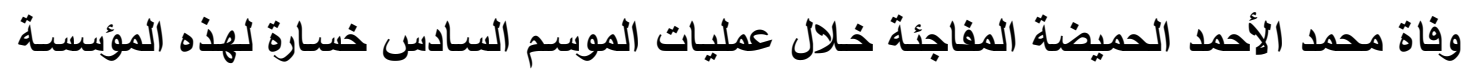
العلمية ومبعث أسى وحزن عميقين لجميع الذين عرفوه وزاملوه طيلة سنين طويلة) (؛ ).

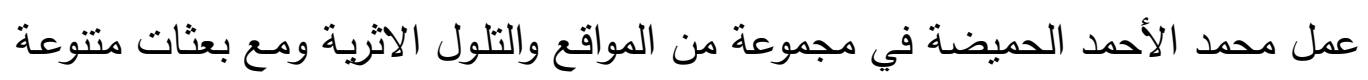

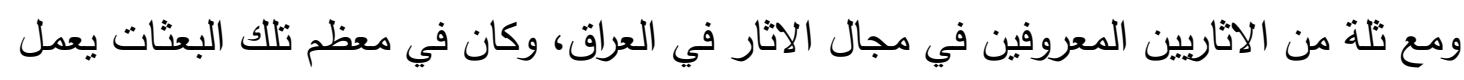

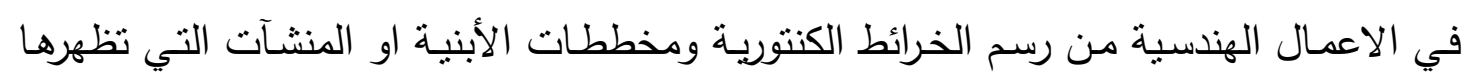

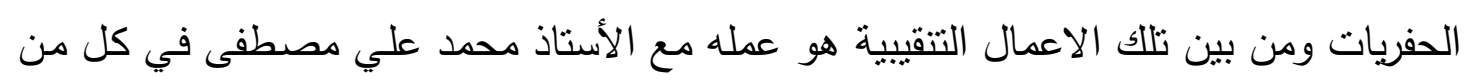

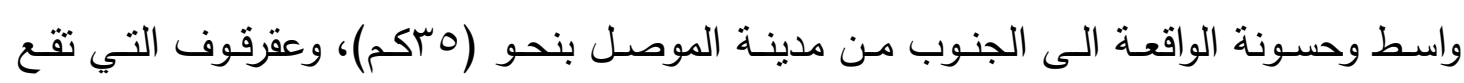

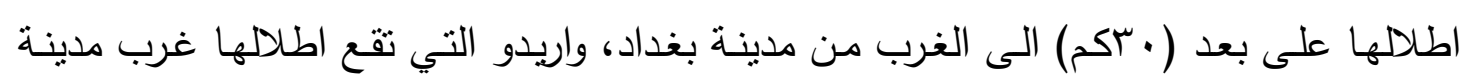

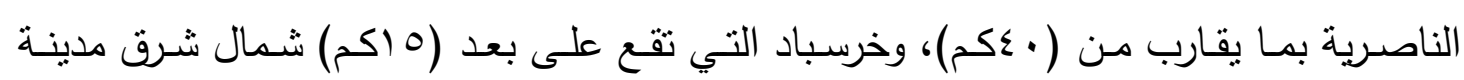

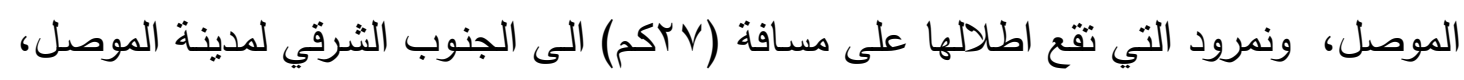

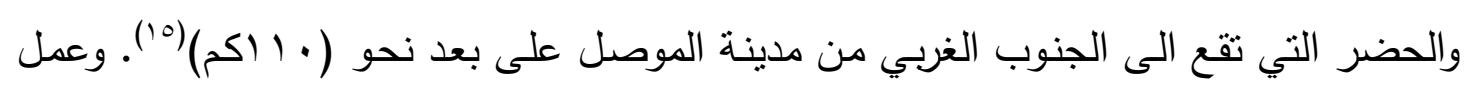


مع الدكتور بهنام أبو الصوف في تتقيات تل باسموسيان (في سهل بتوين، جنوب مركز قضاء

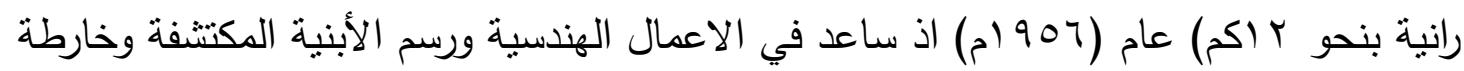

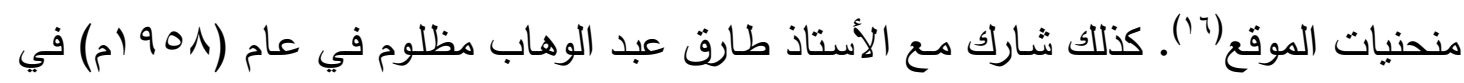

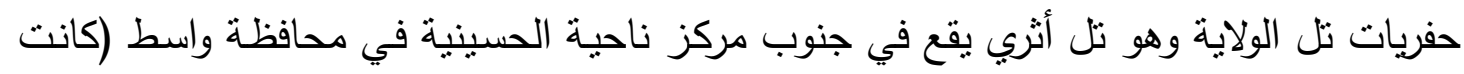

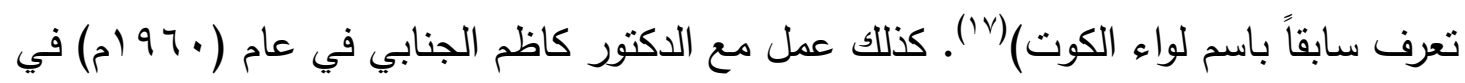

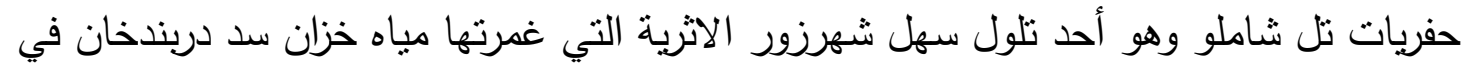

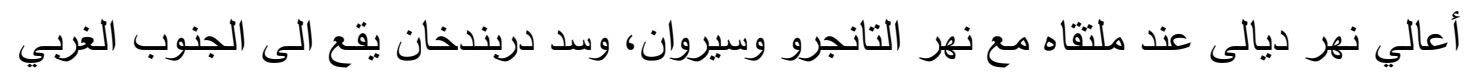

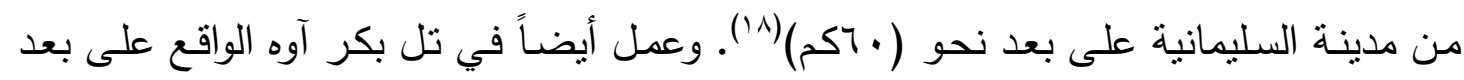

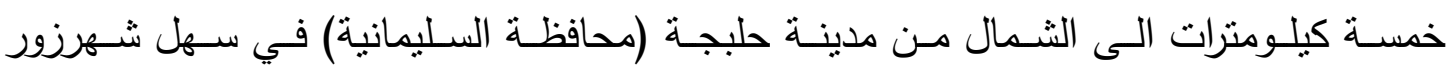
الخصب، مع الأستاذ طارق عبدالوهاب مظلوم في الموسم الأول عام (.97 (م)، ومئ الأستاذ

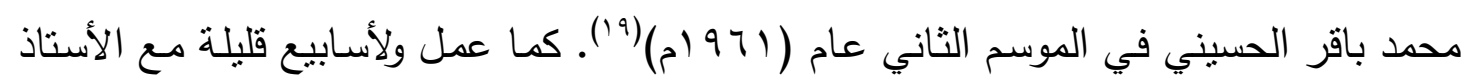

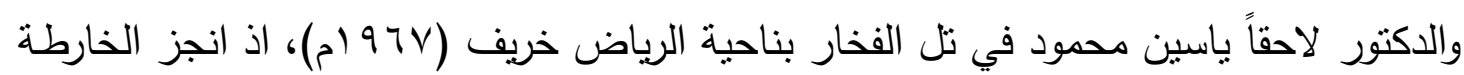

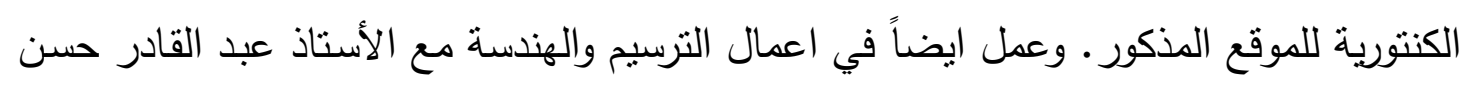

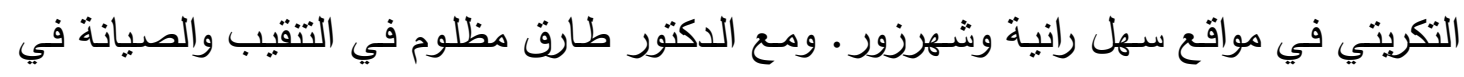

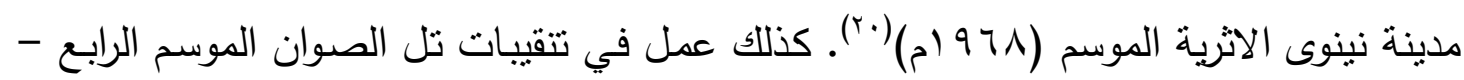

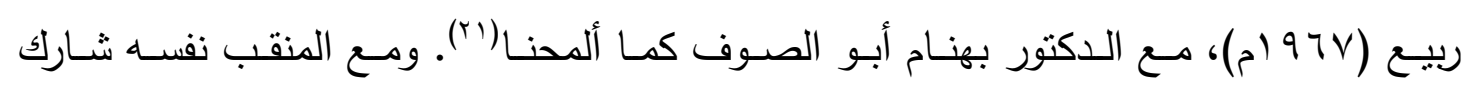

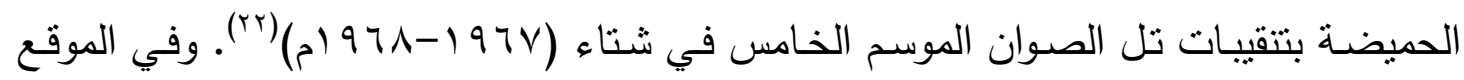

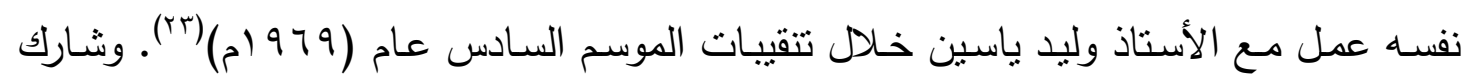

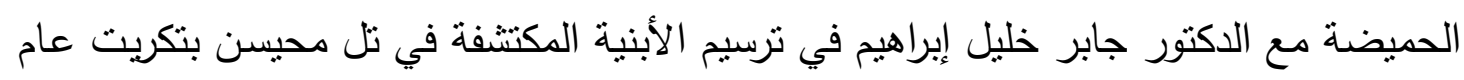

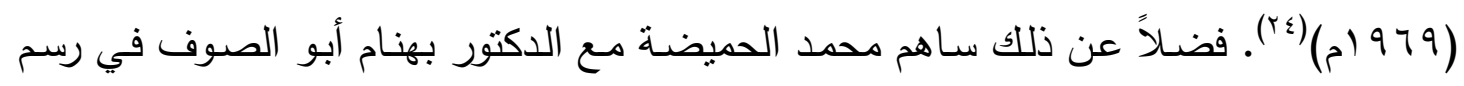

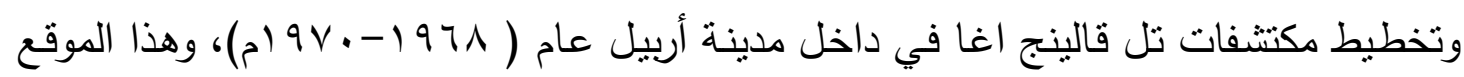

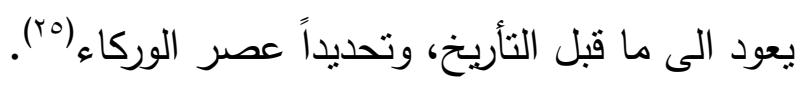

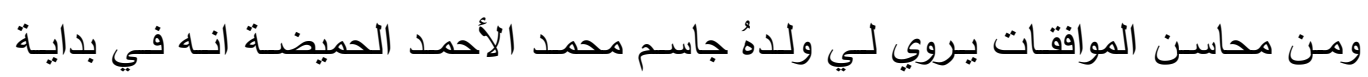

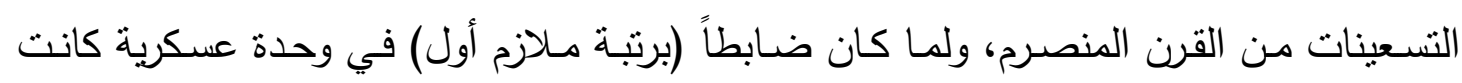

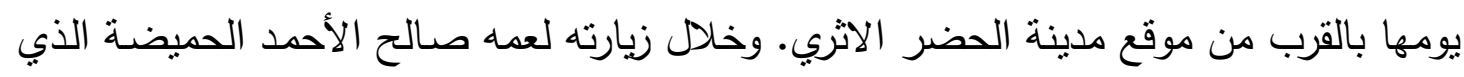

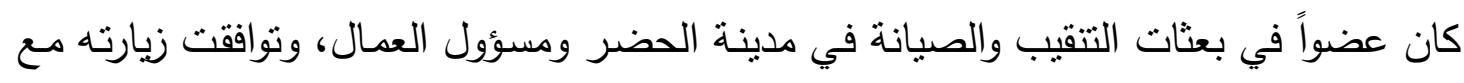
وجود الدكتور بهنام ناصر نعمان أبو الصوف هناك وكان لقاؤهما هو ووالدي وجاسم نجلة ونله لقاءً

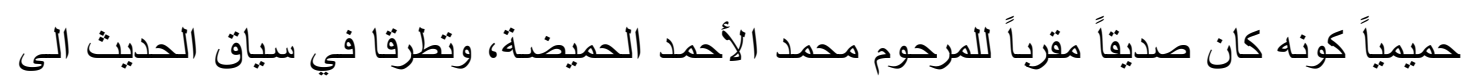

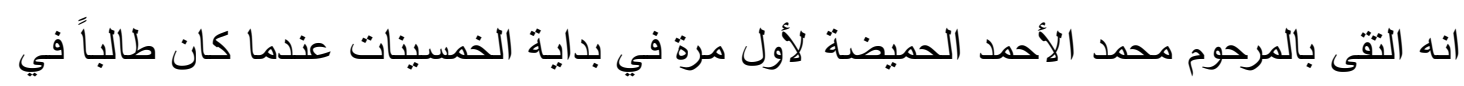

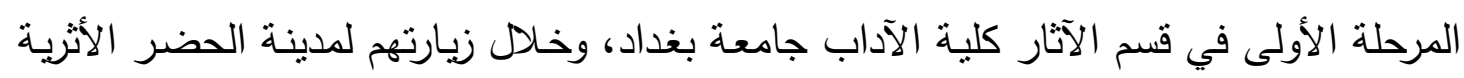


بصحبة أستاذهم (الذبي نسي او يجهل جاسم أسمه واعتقد انه الأستاذ المرحوم فؤاد سفر كما يظهر في الصورة الفوتوغرافية المنشورة في موسوعة المفكرين والادباء العراقيين الجزء الثناني

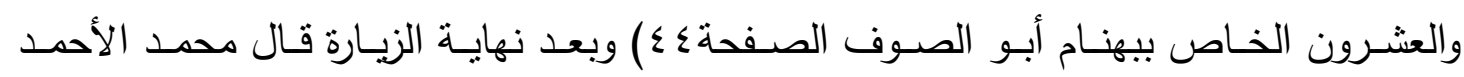

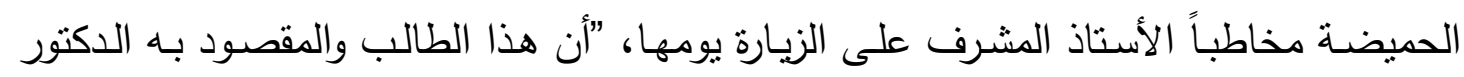

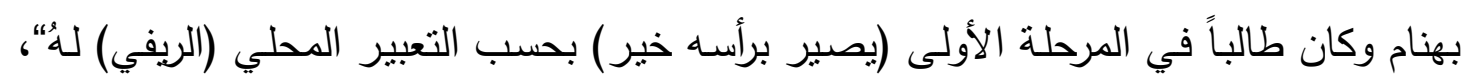

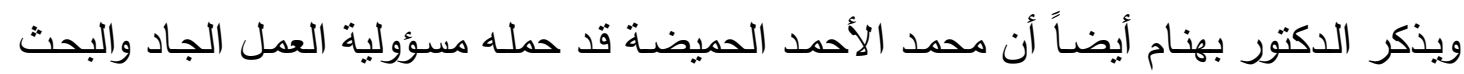
الأثري المستمر للوصول الى ما هو عليه، وكما ذكرنا، ان (أبو الصوف) وزملائه، لقيا تدريباً

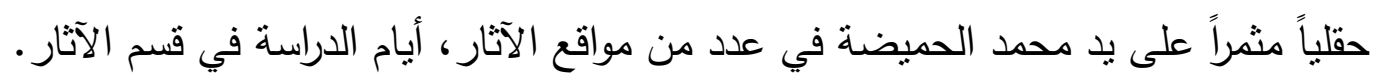

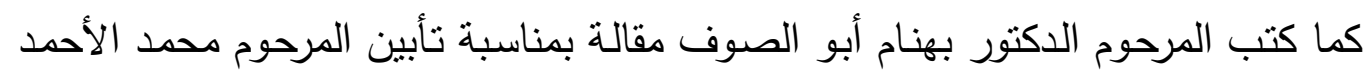

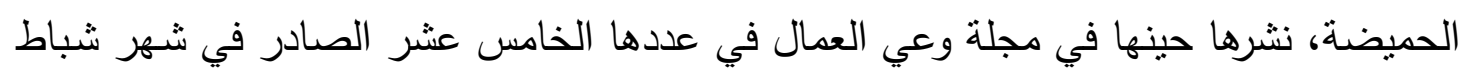

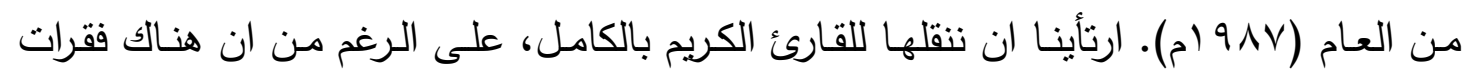

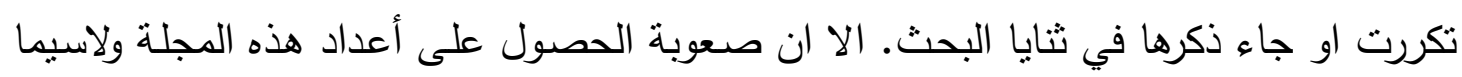

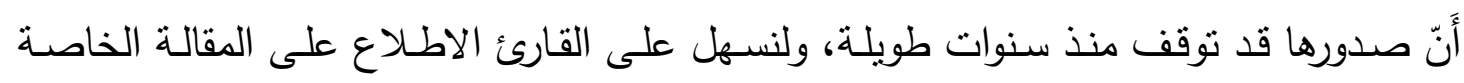

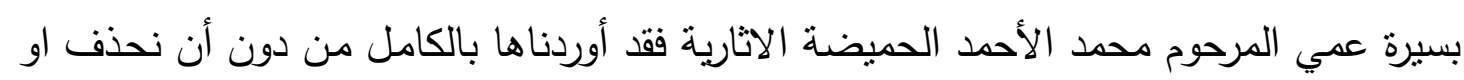
نغير منها أبَّة كلمة او فقرة، وجاء في نص هذه المقالة (عامل في الآثار : صار مساحاً ومهندساً وباحثًا ومخططاته مرجعاً عالمياً، محمد الأحمد الحميضة - عامل في فئ الآثار ، قام بمهام مساح ومهندس حقلي ونشرت مخططاته وخرائطه الاثارية في كتب ومجلات علمية عالمية. عن هذه الثانه الثخصية كتب الدكتور بهنام أبو الصوف في تأبينه يقول: "لقد ساعدني في الاعمال الهندسية فئه

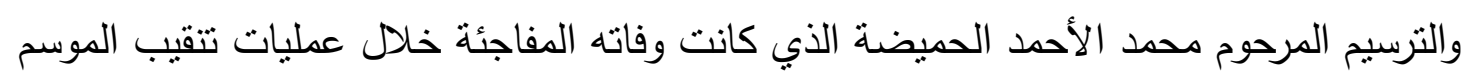

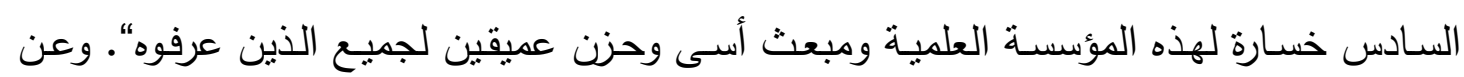

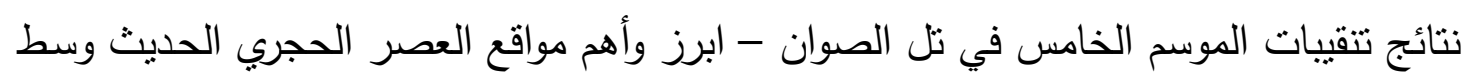

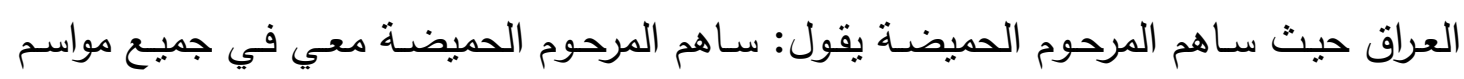

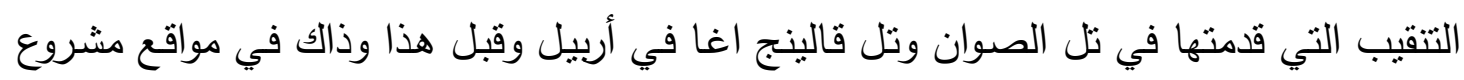
المسيب الكبير وتل باسموسيان في حوض سد دوكان وفي خرساباد ونمرود والحضر والعديد

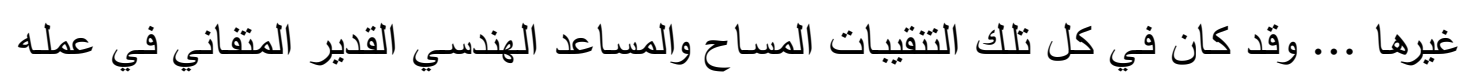

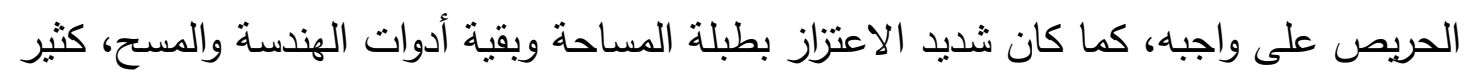

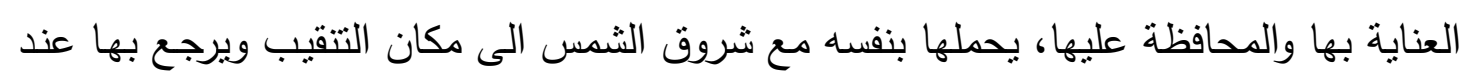
نهاية العمل، وكان يحرص حرصاً شديداً على ما ينجز من رسومات ومخططات ويلفها بعناية

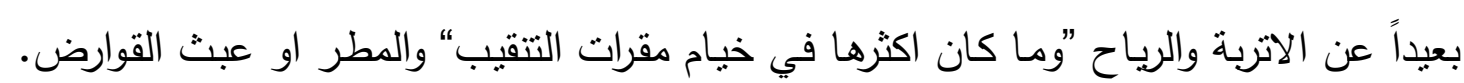


وبالرغم من عدم معرفته للقراءة والكتابة "عدا ما حفظه من ارقام على مسطرة القياس وجهاز

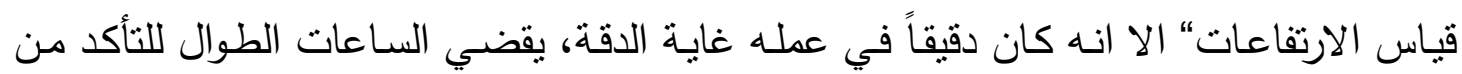

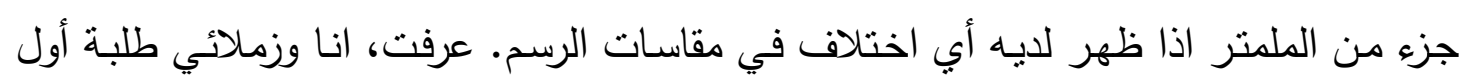

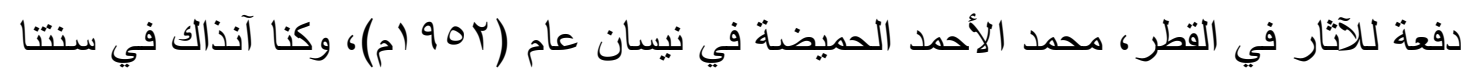

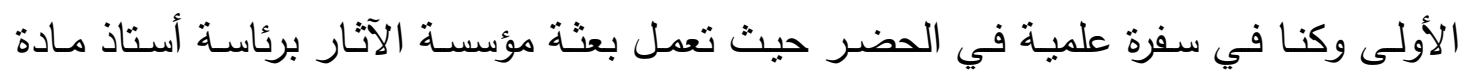
التتقيب المرحوم فؤاد سفر • وجدنا الحميضة منهمكاً في مساعدة مهندس البعثة ورسامها الأستاذ

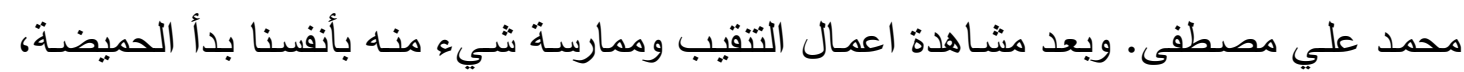

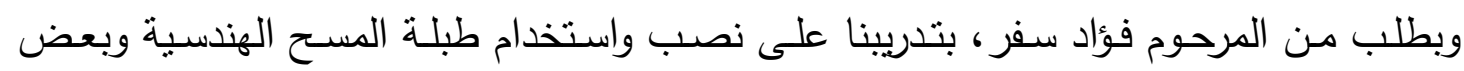

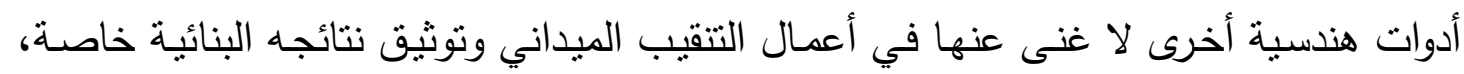
وكان يبدو الحرج والتواضع على الحميضة وهو يشرح لنا، بكلمات بسيطة وبلهجة بدوية محبية،

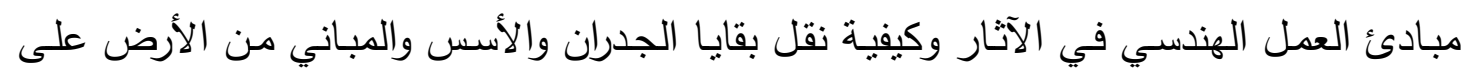

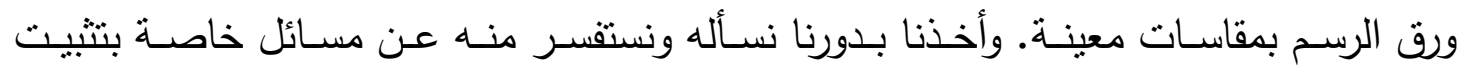

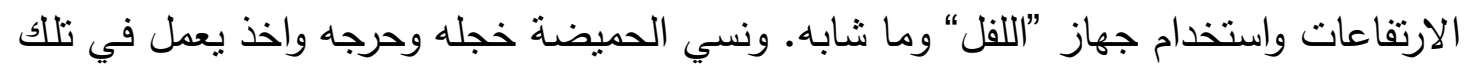

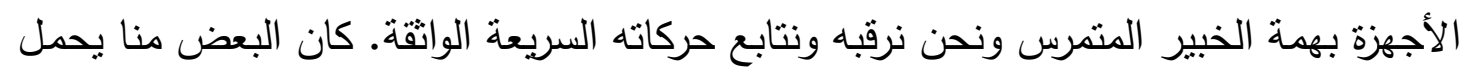

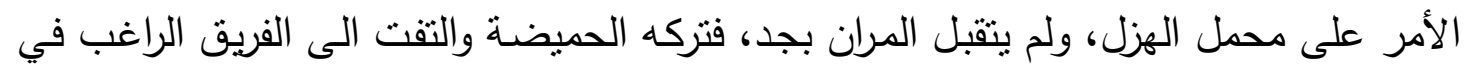

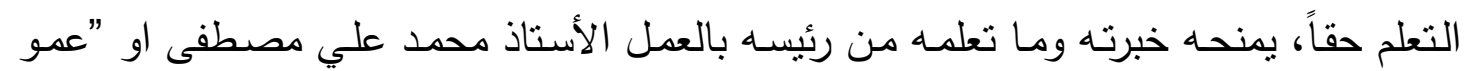

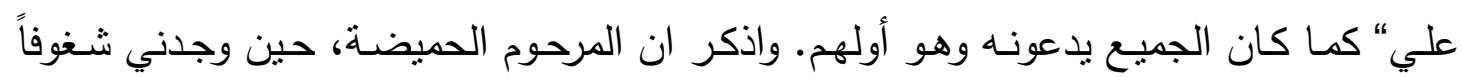
بالتعلم سمعته يقول "للعم علي" بعد انتهاء التدريب في ذلك اليوم: "هذا الولد - وهو يشير بيده إنها

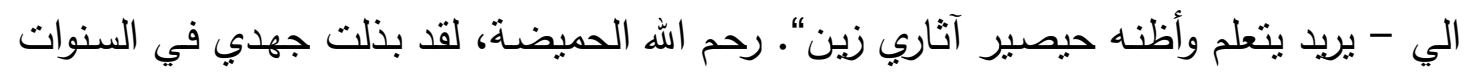

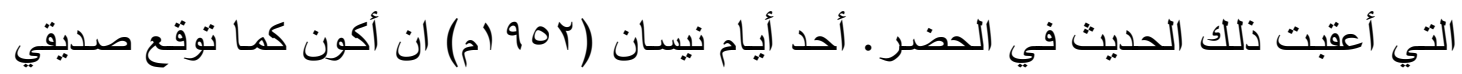
ورفيق دربي الطويل في الآثار ، ولعلي، بقدرته تعالى، قد استطعت ان احقق بعض ما ما توقعها

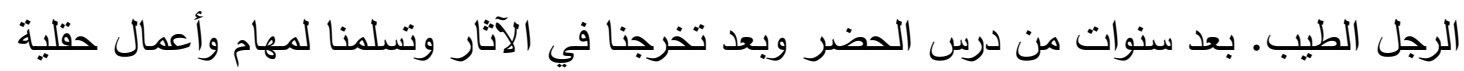
لأول مرة في مشروع المسيب الكبير ، في أواسط الخمسينات حيث كانت الثاخات تقطع والمبازل

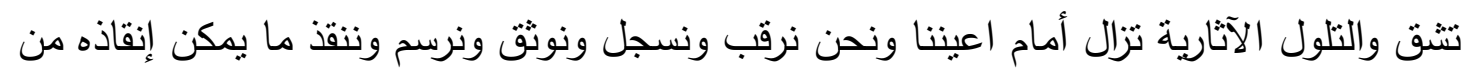

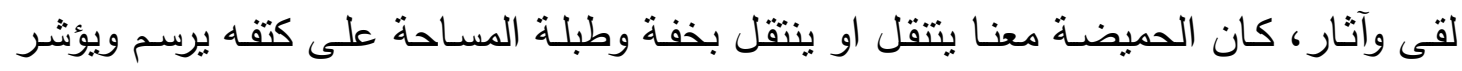

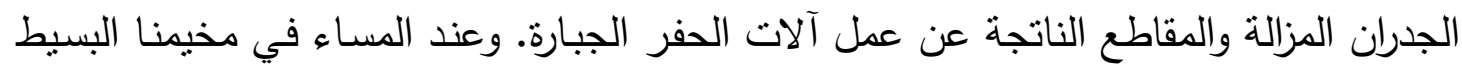

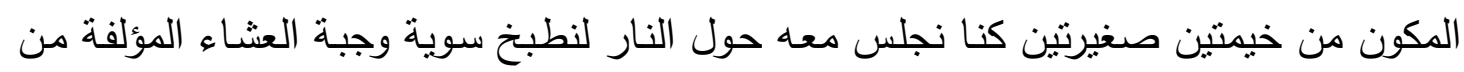

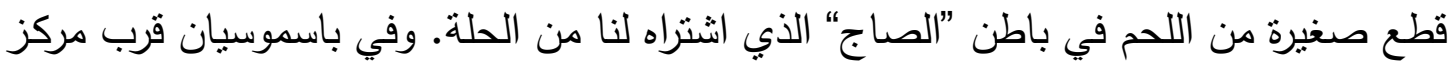

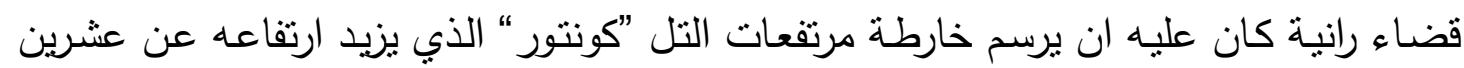

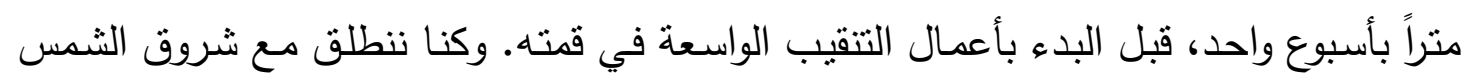


من مخيمنا عند حافة الزاب الصنير باتجاه التل على مسيرة كيلومتز تقريباً وهو يحمل بيديـه آلات العمل الدقيقة يرفض ان يساعده أحدنا في حملها خشية اصسابتها بتلف او اسقاطها على بلى الأرض. بهذا الحرص وبهذا التفاني في عمله اليومي المتكرر ولسنوات طوبلة جاوزت الثلاثين حصل المرحوم الحميضة على محبة واحترام كل من عرفه او عمل معه وزامله. كان صبوراً لا يتعب من العمل، رغم ضعف صحته، اشد ما كان بضايقه مزاح بعض الزملاء وعدم جديتهم في الحديث. ولد الحميضـة ونشـأ كغيره من عمال الآثار "الأسطوات، الماهرين في قرى السديرات، في قضاء الثرقاط، الكائنة على أمتداد ضفة دجلة الشرقية قبالة آثور ، أول عاصمة للآشوربين، وقد عمل ابوه في الآثار وكان من "الأسطوات“ البارزين فيها، ونشأ ولده محمد الأحمد على حب الآثار والعمل في مواطنها متتقلاً مع بعثات الآثار العراقية بين مواقعها. بدأ حياته عاملاً صغيراً في واسط، مدينة الحجاج، في أواخر الثلاثثينات يوم كان المرحوم الأستاذ ساطع الحصري مديراً للآثار وقد تتبه الأستاذ محمد علي مصطفى مساح ومهندس بعثة التتقيب في المدينة العربية الإسلامية، الى ذكاء ونباهة وجدية الصبي الحميضـة فاختاره ليحمل أدوات الهندسة ويتتقل معه بين بقايا المدينة البنائية وانقاضها: يمد شريط القياس تارة ويمسك بمسطرة الارتفاعات تارة أخرى. ومن واسط ذهب مع "عمو علي" الى حسونة وعقرقوف واريدو والحضر • وسنة بعد سنة وبتعاقب

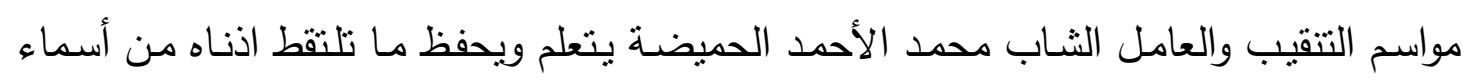
ومصطلحات هي من اختصاص المهندسين والمساحين. تعلمها كلها واتقنها عملياً فصار يعرف بين جماعته ورفاقه عمال الآثار "الثرقاطيين" بالمهندس. وقد كان رحمه الله فعلاً مهندساً، ولكن دون ان يحصل على شهادة بالهندسة او المساحة، ولا حتى على شهادة الدراسة الابتدائية. ساعد وساهم ورسم بنفسه العديد من الرسوم الهندسية والخرائط والمخططات المعقدة لمباني وقبور وبقايا

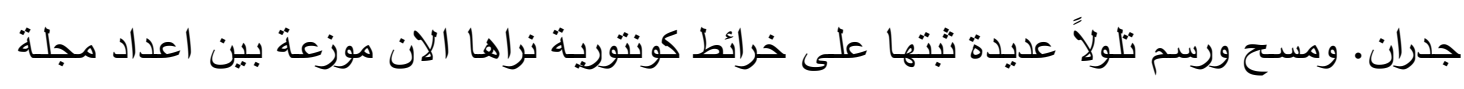
سومر صحبة بحوث وتقارير لنتقيات المواقع كما دخل بعضها في كتب ورسائل اثثارية جامعية. توقف قلبه الضعيف عن العمل وهو يرسم ويخطط في تل الصوان، قرب سامراء، في أحد أيام

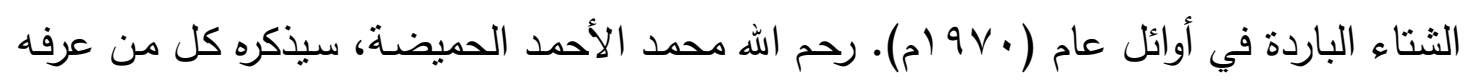

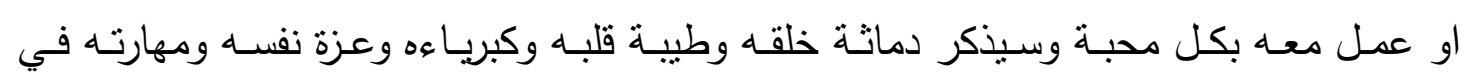
(العمل)(بT)

ثانياً : صالح الأحمد الحميضة : انصرف صالح الأحمد الحميضة إلى أعمال التنقيب، فأجاد مسكة المعول، وميَّز الطبقات البنائية الهثة منها والصلدة، فجال مواقع التتقيب بالعراق، حتى استقر في الحضر بعد أن قرَّر المرحوم الدكتور ناجي الأصيل المباشرة بالتتقيب في أطلال هذه المدينة عام (1901 (م). 


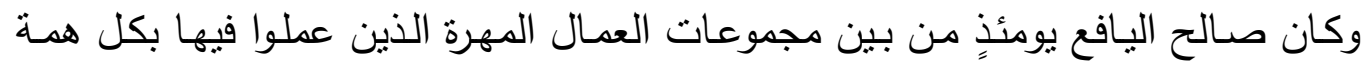

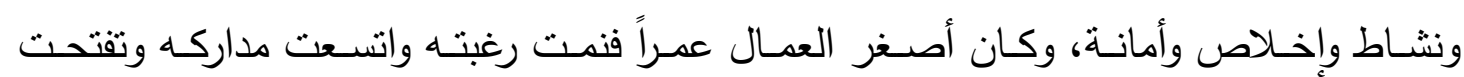

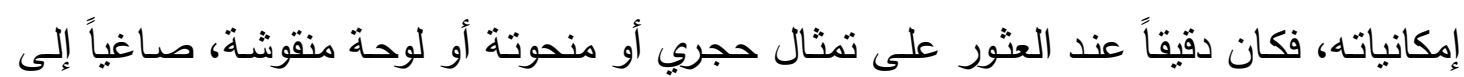

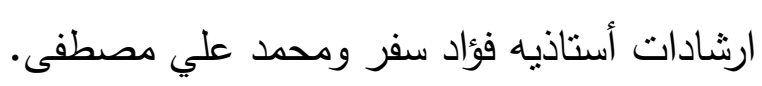

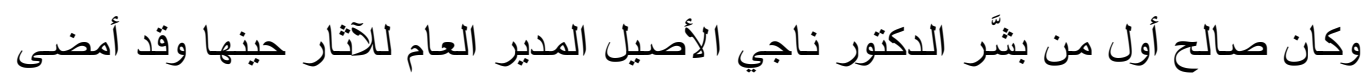

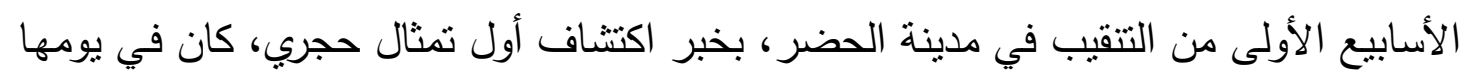

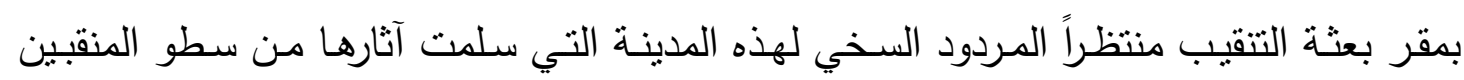

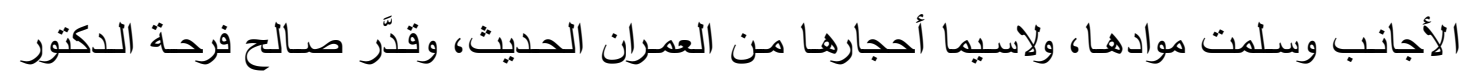

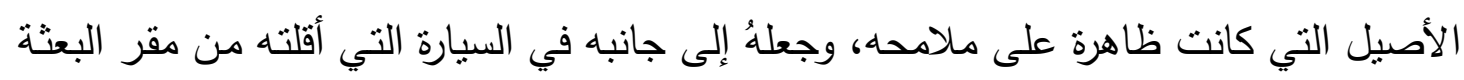

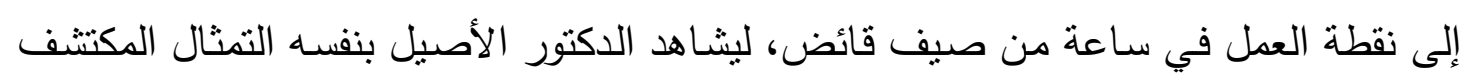
في احد المعابد الصغيرة، وأسلوب نقله من معثره.

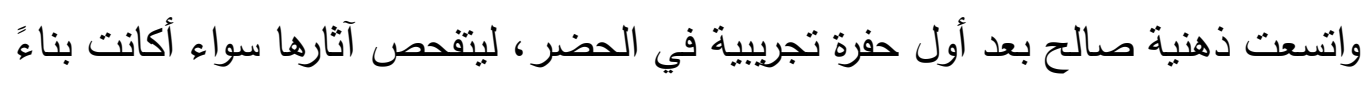

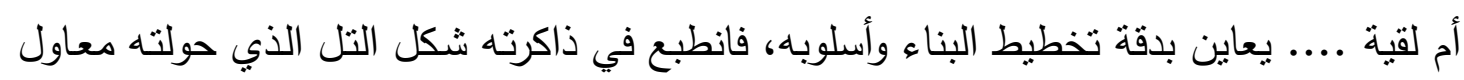

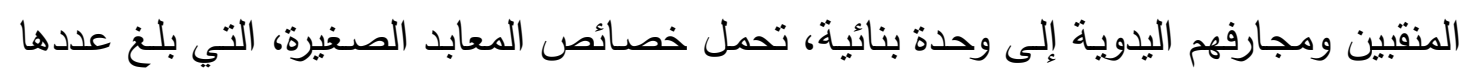
حتى الآن أربعة عشر معبداً، وساهم صالح في اكتشافها وتتقيبها.

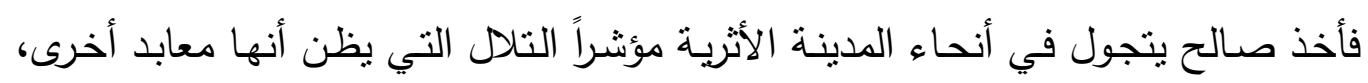

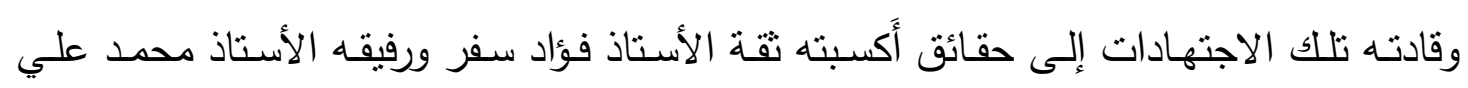
مصطفى. وبعد أن انتقلت دائرة الآثار من مرحلة التتقيب في أطلال مدينة الحضر إلى التحري في

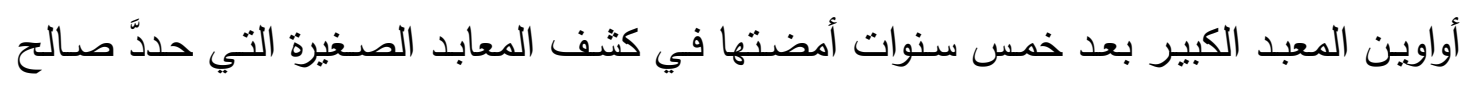
معالمها قبل حفرها، فلاحظ هذا الرجل الأمي درجات تساقط الحجارة من جدران الأواوين العالية

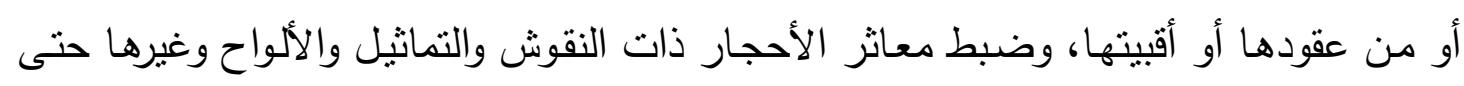

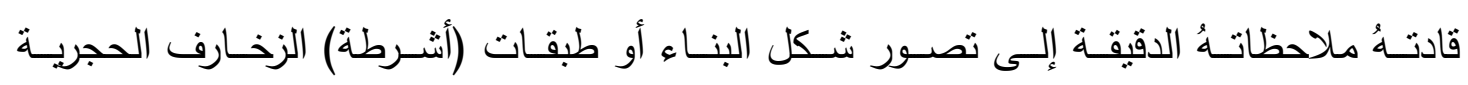
وأصنافها (rV)

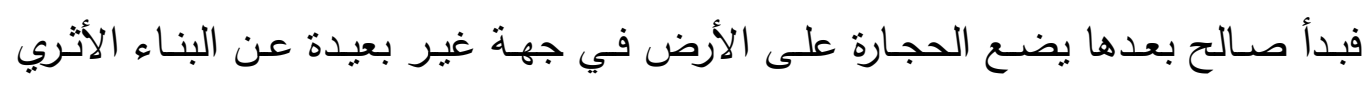

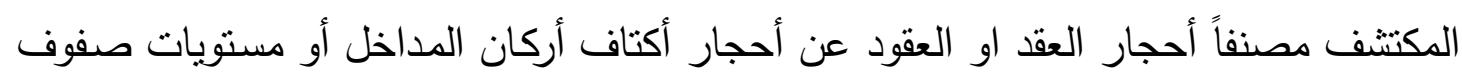

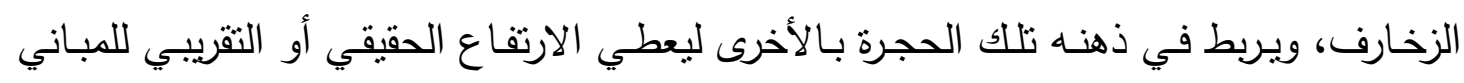
الاصلية ومهما كانت درجات انهيار جدرانها. وظَّف صالح ملاحظاته هذه في الصيانة المعقدة التي أجرتها دائرة الآثار لمباني الاواوين

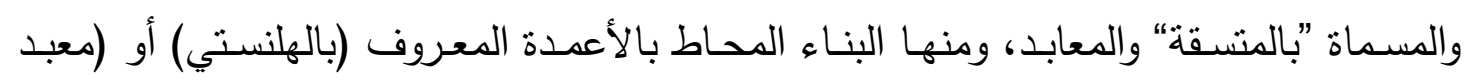


مـرن) مسـتقبداً مـن ارشـادات وخبرة أستاذه محمد علي مصطفى، الذي يعـود اليهـ الفضـل في في صيانة هذا المعبد حتى مراحله النهائية.

وسنقدم للقارئ الكريم بعضاً من مساهمات المرحوم صالح الأحمد الحميضة ومشاركاته مع هرئه هيئات التنقيب، اذ عمل صالح في ثل ”بكم" بمشروع شهرزور في الأول من شهر تشرين الأول العام ( • ج 9 (م) وكان رئيس هيأة التتقيب في ذلك التل ورئيس المشروع هو الأستاذ محمد علي مصطفى. كذلك عمل مـع هيئات التتقيب والصيانة الاثريـة في مدينـة الحضـر، إذ تفيد ثقارير

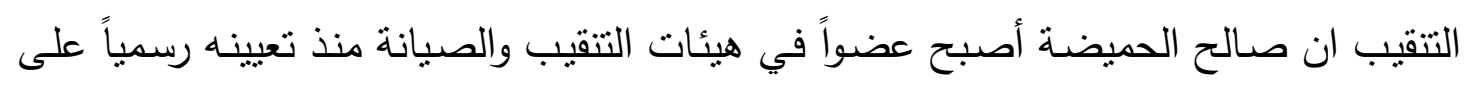

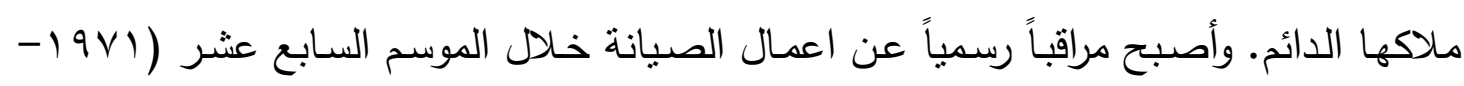

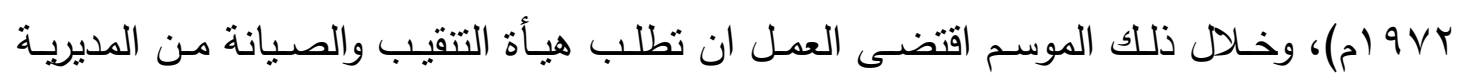
العامـة للآثار في بغداد باستقدام السـادة: المرحوم الأستاذ محمد علي مصطفى لاسنشارته في الأمور الفنية الخاصة بإكمال المرحلة الأخيرة من صبانة معبد مرن (المعبد الهلنستي) كما أسلفنا قبل قليل وصيانة مرحلة أخرى من معبد اطلق المنقبون عليه اسم معبد العجول وابنية عدد من

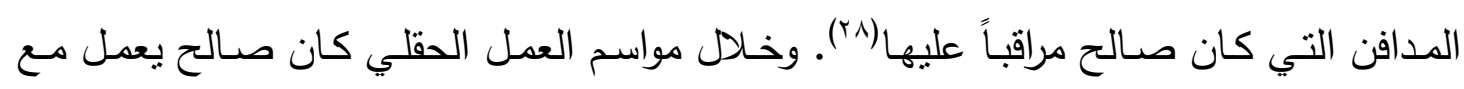
بعثات التقفيب والصيانة في انحاء متعددة في مدينة الحضر التي أصبحت بيته الثاني فكان

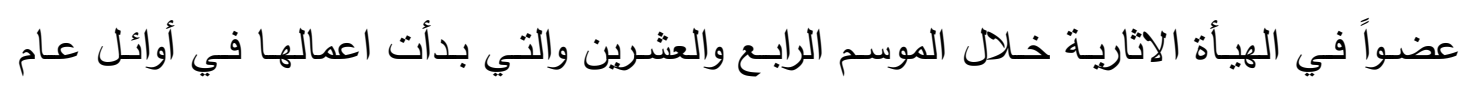
(9V^ (م))، وكانت الاعمال مركزة على استظهار احد المعابد الصغيرة المعروف باسم المعبد الثاني عشر (معبد الاله نبو) الكائن في الطرف الجنوبي من حارة المعابد الرئيسـة في مركز مدينة الحضر (rq). وفي موسم العمل نفسه أشرف صالح الحميضة على أعمال الصيانة في معبد "السقايا" الواقع في اقصى الزاوية الجنوبية الغربية من ساحة المعابد الرئيسة(·r). كذلك شارك في تتقيب البناية المكعبة التي بدأ العمل فيها من الأسبوع الأول لشهر آب العام (9 9 (م) واستمر لغاية نهاية السنة ذاتها وترأس بعثة التتقيب تلك الدكتور جابر خليل إبراهيم الأستاذ في جامعة الموصل ('آ). والى جانب تلك التتقيبات لازم المرحوم صالح الحمبضة التتقيب في الحضر ، وكان عضواً فعالاً في هيئاتها سواء العاملة في التنقيب ام في الصيانة. والطريف في الامر ان ابنه

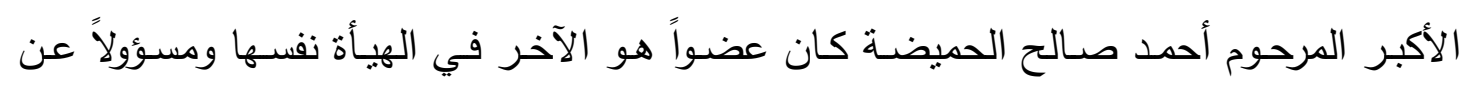
أعمالها الحسابية. فعمل صالح الى جانب أعضاء الهيأة التتقيبية خلال الموسم السابع والثلاثين العام (ب99 (م) في تتقيب بيتين سكنيين بقعان الى الجنوب من المعبد الكبير من جهة معبد

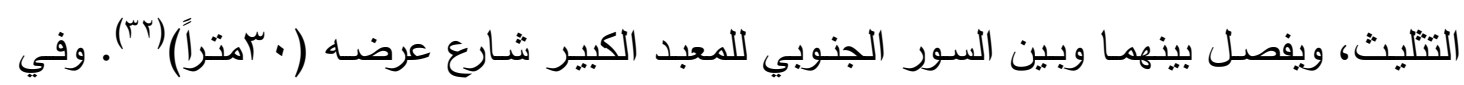
موسم التتقيب نفسـه للعام (Y99 (م) شـارك المرحوم صسالح الحميضـة الهيأة في تتقيبات المعبد الرابع عثر الواقع على بعد نحو (• ومتراً) الى الجنوب الغربي من الزاوية الجنوبية الغربية لسور 
المعبد الكبير ، وشرعت هيأة التققيب التي كان من بين أعضائها صالح الحميضة وولده أحمد في التتقيب في هذا المعبد في أوائل شهر حزيران من العام (Y99 (م) ولغاية شهر تشرين الأول من

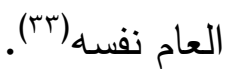

وكانـت مناقثـات صـالح الحميضـة مـع المختصـين في الآثار الحضـرية جـادة وعلميـة

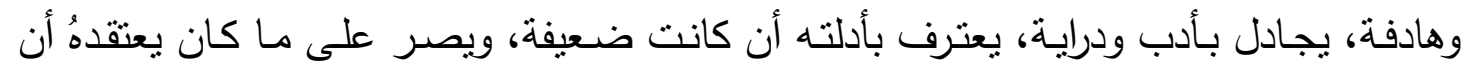
كانت أدلته رصينة، يحاور المنقبين بأسلوب منطقي وبخبرة سنوات طوال قضاها منقباً أو مشاركاً

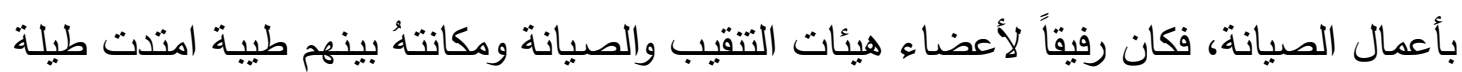
مواسم العمل.

ولم تقتصر قابليات صالح الحميضة على الجوانب الفنية بل تعلّم الأبجدية الحضرية وبدأ يقرأ النصوص الآرامية المكتنفة، مميزاً بين المتثابه في رسم بعض حروفها ويترجمها. وأمضى هذا الرجل الطيب وبكل همة سنوات طويلة من عمره يعمل بأجور يومية في دائرة الآثار حتى تم بعمئ

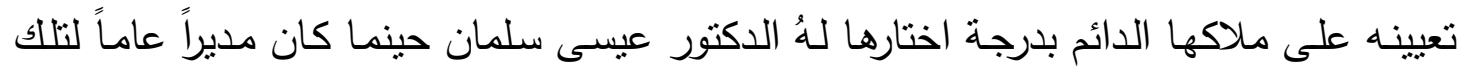
الدائرة تقديراً لخدماته الطيبـة في حقل الآثار، فاستمر منذ عام ( (9VI (م) كعضو في هيئات التتقيب والصيانة السنوية في الحضر ، وأصبحت الحضر في مفهومه بيته وخيمته، فيها ينشرح صدره، وبآثارها تتجدد تفسيراته لها ... يقضي النهار ساخناً كان أم بارداً يتفص ذلك الجدار، أو ينظر إلى ذلك القبو أو إلى واجهات الأواويـن الحجريـة العاليـة، متـأملاً في أسـلوب تقبيـة اواوينها أو في تقنية العمل يوم بنائها. وخلال سنوات التققيب في مدينة (الحضر مدينة الثمس) واكتشاف الكنوز الاثرية وخاصـة

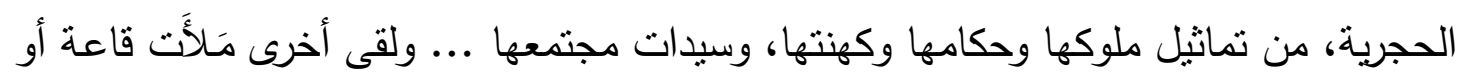
أكثر، في المتحف العراقي ببغداد وفي المتحف الحضـاري في الموصـل، كمـا زبنـت تماثيـل الحضربين او قطع فنية أخرى زبنت متاحف المحافظات العراقية الأخرى. ونشطت معها رغبات الباحثين في دراسة الفنون والجوانب التاريخية منها واقبل المختصين عراقيين كانوا أم أجانب على على هذا الحقل الجديد كحضـارة ورثت عن الآثوريين وأسـلافهم، وأوصلت ما كان عليه العرب قبل الإسلام، فكان صالح الحميضـة سخياً في معلوماته التي وثقها في ذهنه، وأوقفها لطلاب العلم، فأحبهُ من قابلهُ ومن استعان بـه، ويكفي أن يكون اسمهُ في اطاريح الباحثين ممن حصلوا على شهادات الماجستير أو الدكتوراه من جامعات القطر أو من جامعات أوربية أو أمريكية، ومن بين تلك الثـهادات أطروحة الدكتوراه الموسومة : Pre-Islamic settlement in Jazirah) الاستيطان في الجزيرة فبل الإسـام على ضوء الحفريات في الحضر وجدالة، للاكتور جابر خليل إبراهيم والتي حصل عليها من معهد الاثار بجامعة لندن المملكة المتحدة (بربطانيا) بإشراف اثتين من كبار الاتثاريين في اوربـا هـا البروفيسور ديفيد اوتس والمختص بـالفرثينين الدكتور 
مـالكولم كولج(ء). ويذكر لي استاذي الفاضل الأستاذ الدكتور جابر خليل إبراهيم ان لوالدي

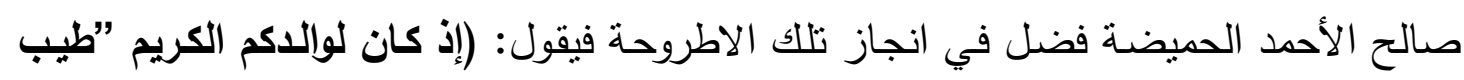

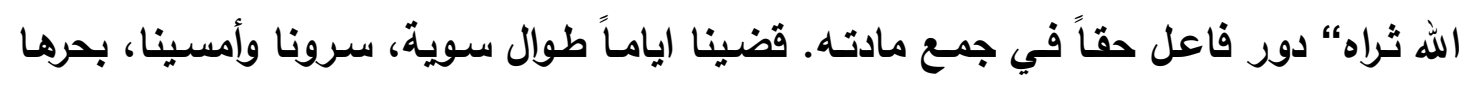

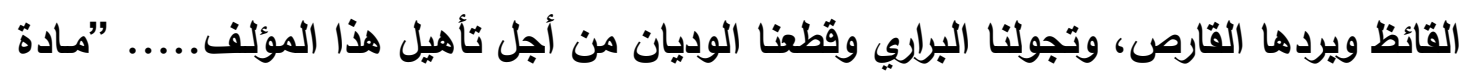

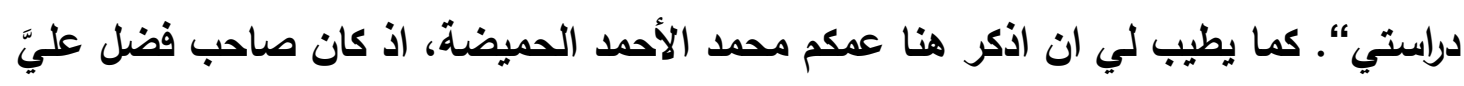
وعلى زملائي المنقبين في هيأة الاثار ...... كلاهما صالح ومحمد أذكرهما باحترام وتقدير) (بمان.

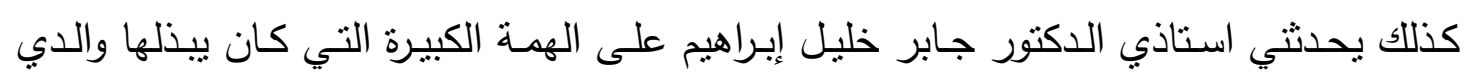

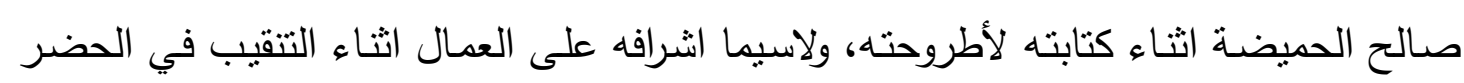

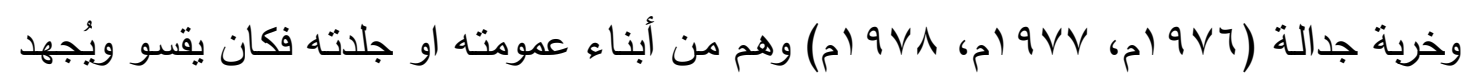

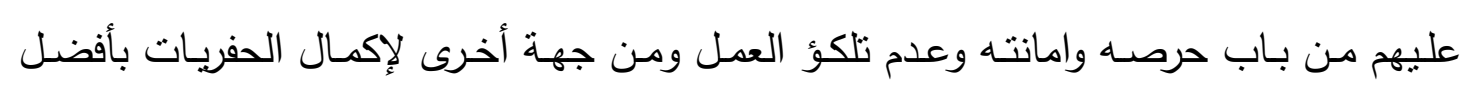

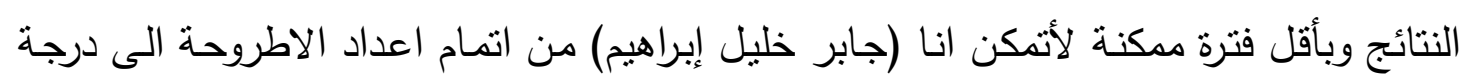

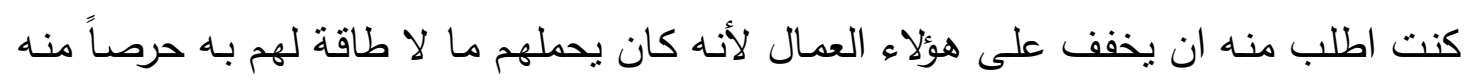

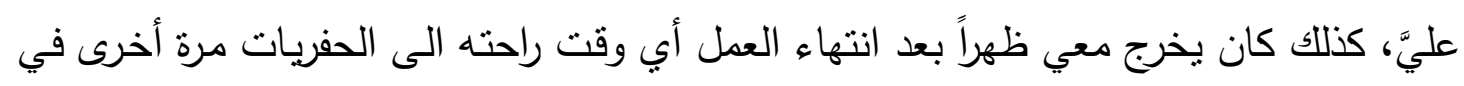

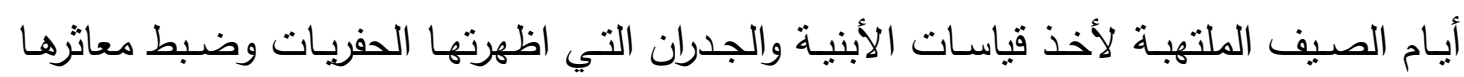

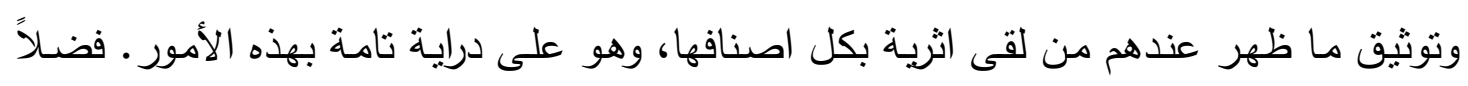

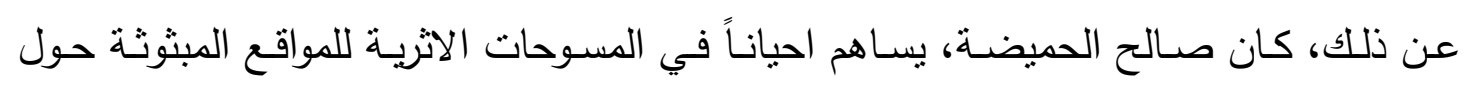

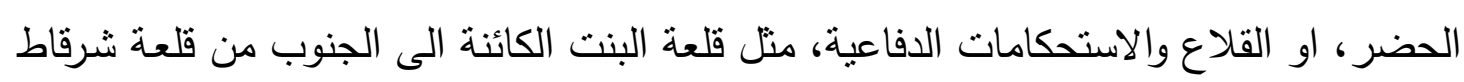

(آثور)، وقلعة (قصر ) الجبار التي تعلو بقاياها سلسلة مرتفعات مكحول (باتهات.

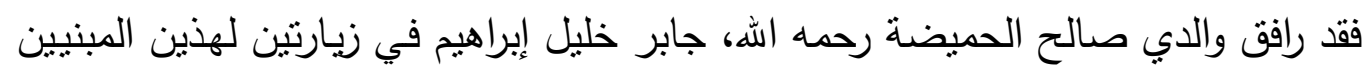

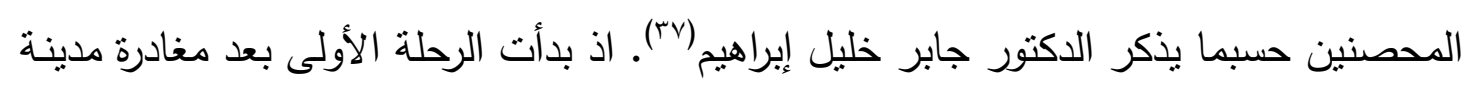

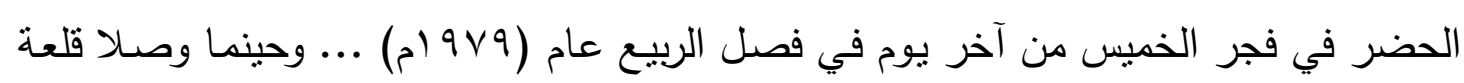

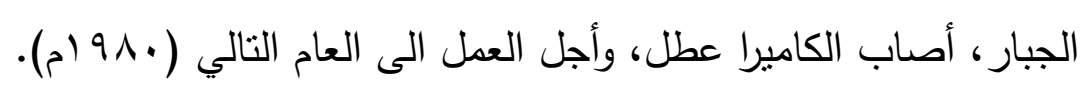

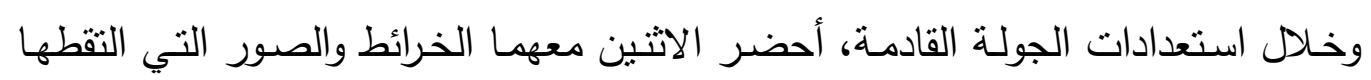

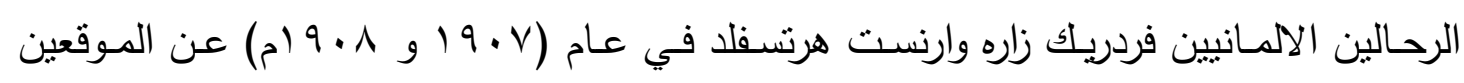

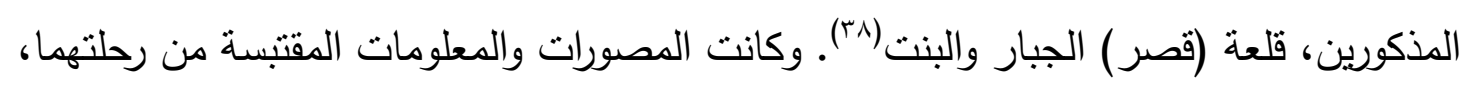

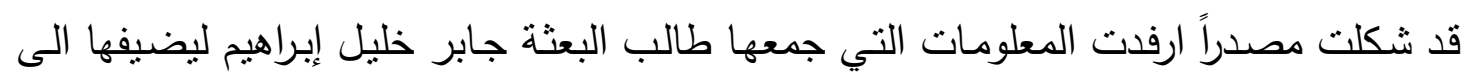
اطروحته التي كان يعدها في معهد الاثار ، بجامعة لندن.

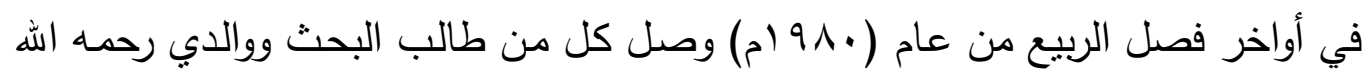
قلعة الجبار في ساعة مبكرة، وتجولا في عموم ارض القلعة وقاما بتصوير المخلفات البنائية، 


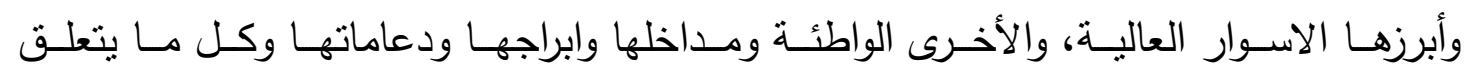
باستحكاماتها الدفاعية، من قلاع وابنية أخرى ذات العلاقة بها. والتقطا بعض القطع الفخارية وإن كانت في الأصل قليلة. غادرا قلعة الجبار، واتجها الى قلعة البنت، والتقطا بعض الصور الفوتوغرافية. وسبق أن زارها الدكتور جابر خليل إبراهيم في صيف عام (TVY (م)، وكتب وصفاً لبقاياها... اتجه كل من الباحث ووالدي رحمه الله الى قصبة ناحية الزاب وعبرا جسراً خشبياً، حيث وصلا بيتاً كريماً هو مضيفهما المكنى (أبو طلب) وهو خال والدي، وقد تتاولا طعام الغداء(ra). قدَّم والدي المساعدات العلمية المعهودة ولاسيما طلبة البحث في الدراسات الأولية والعليا في الجامعات العراقية ممن بدرسون عن آثار الحضر وفنونها، وقد كتب بعظهم الثكر والعرفان لوالدي صـالح الأحمد الحميضـة في مقدمـة رسـائلهم او اطساريحهم ... ولم تسعفنا الذاكرة، الا للقليل منهم ومنهم... السيد ماجد عبدالله الشمس، وقد جاء شكره لوالدي في مقدمة رسالته عن (عمارة الحضر) في عام (970 (م)، الحاصل فيها على شهادة الماجستير، وكذللك في كتابه:

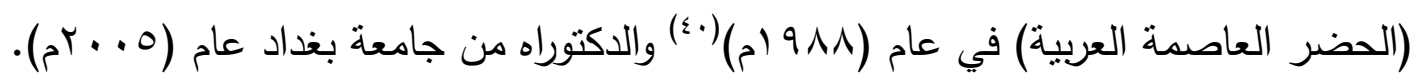
والثكر الذي كتبه رفيق صالح، الدكتور جابر خليل إبراهيم، في صفحة الثكر والعرفان

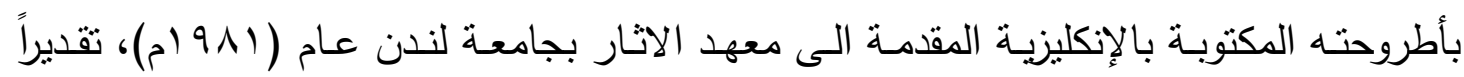

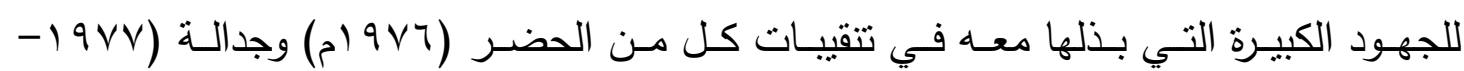
AVA

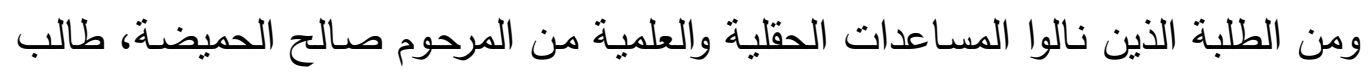

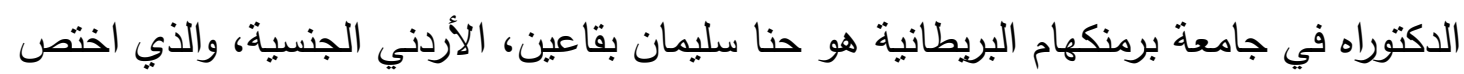

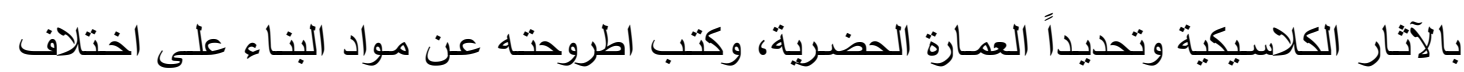
أنواعها، قدمّها كما أسلفنا الى جامعة برمنكهام البربطانية، ونال فيها شهادة الدكتوراه ... وقد لقي الدكتور حنا بقاعين مساعدات قيمة، من والدي اثثاء تحضبر اطروحته ... وبقت تلك الاطروحة غير منشورة حتى الوقت الحاضر ...، ويتعذر علينا ذكر عنوانها على وجه الدقة ... فيما بعد أصبح الدكتور حنا بقاعين استاذاً للآثار الكلاسيكية (اليونانية والرومانية) في قسم الاثار بكلية الآداب جامعة بغداد، للسنوات من (سو 99 ו-r . . rم). كان طالب الماجستير من كلية الفنون الجميلة بجامعة بغداد، حمد سلطان السعدون، قد

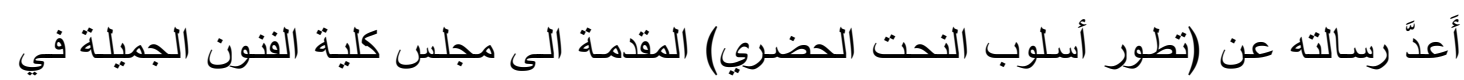
جامعة بغداد عام (9/1 (م)، للحصول على درجة الماجستير في النحت، وقد أهدى الباحث بعد

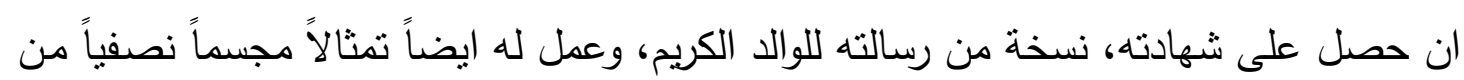


خذما المسيرة الاثارية في العرلق

فضلاً عن ذلك فقد قدمّ صالح الحميضة المساعدة في عدد كبير من البحوث المختصة

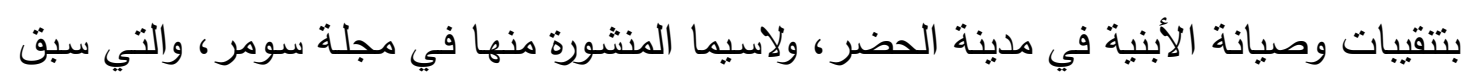
وتطرقنا الى قسم منها.

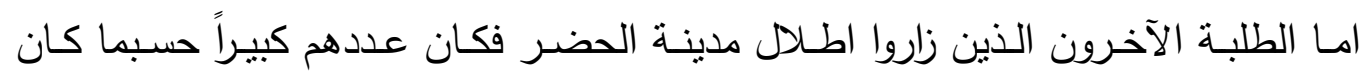

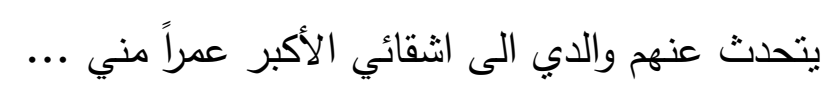

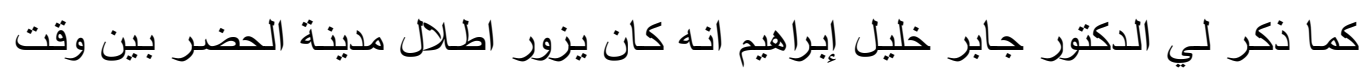

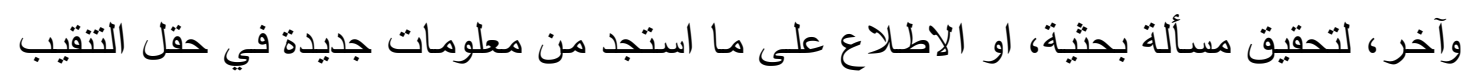

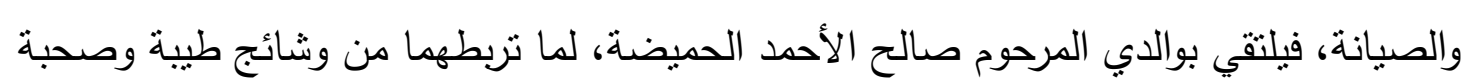

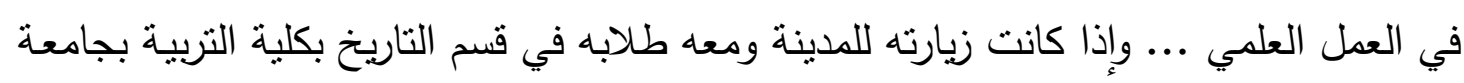

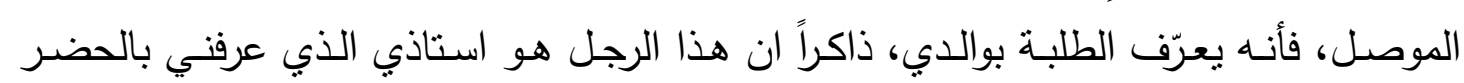
وعمارتها واستحكاماتها، وفضله عَليَّ كبير منذ كنت طالباً. ومن الجدير بالذكر ان رئيس تحرير مجلة آثار الرافدين الغراء الأستاذ خالد سالم اسماعيل.

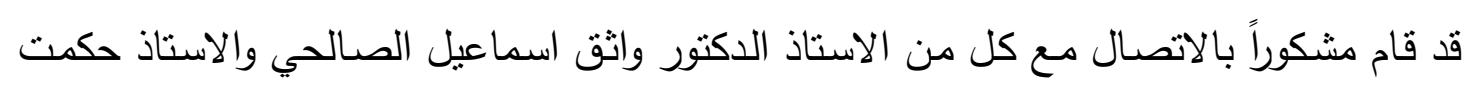
بثير الأسود، حول دعم موضوع بحثي بشهادتيهما وكانت نص اجابتيهما الآتي:

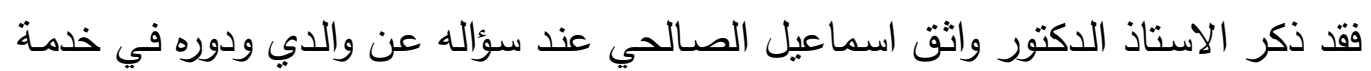

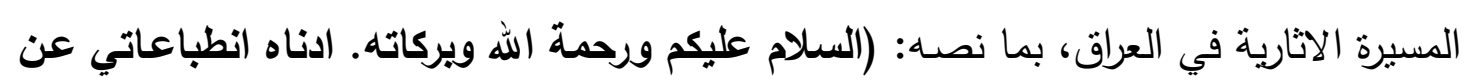

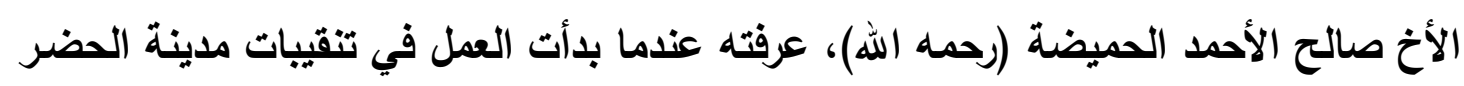

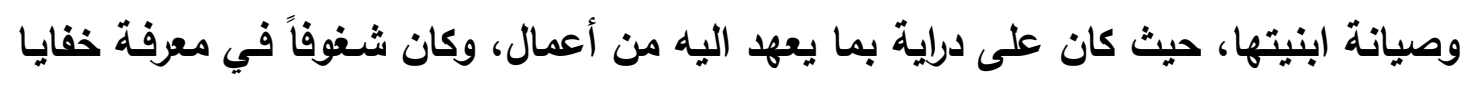

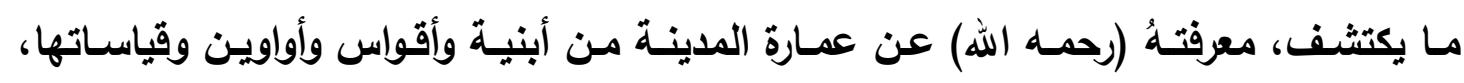

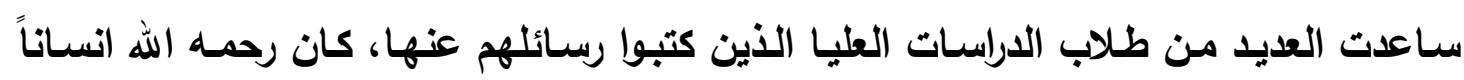
كريماً يحب الخير وينشره بين زملائه العاملين في التنقيب والصيانة).

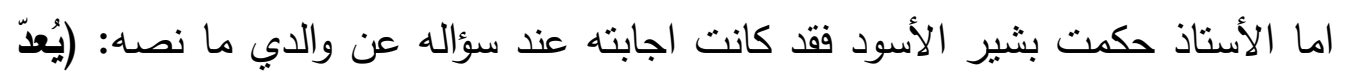

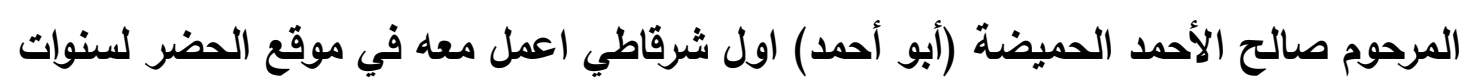

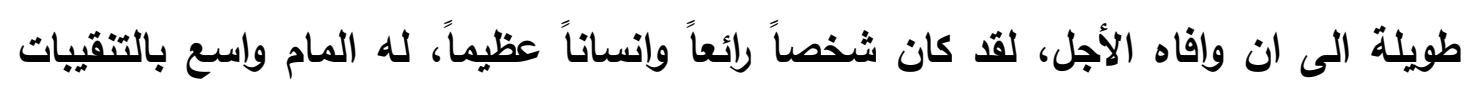

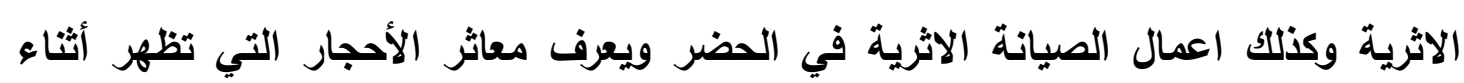

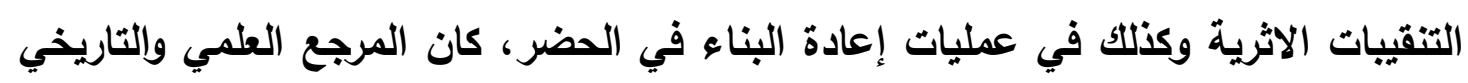

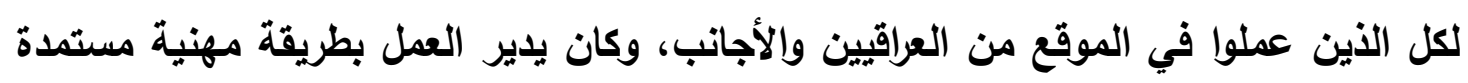

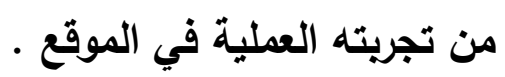


لقد عمل مع الأستاذ المرحوم فؤاد سفر والأستاذ المرحوم محمد علي مصطفى

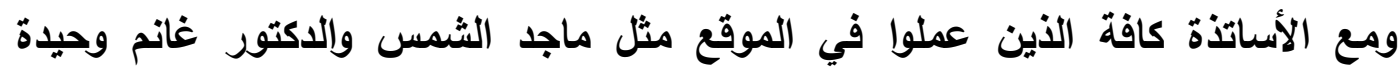
والدكتور جابر خليل والدكتور محد صبحي عبدالله وكنلك مع الهيئات الأجنبية العاملة فيلة فئل

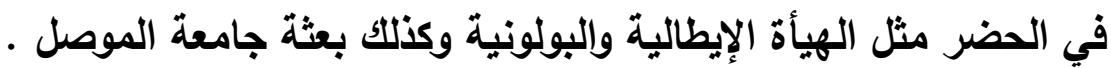

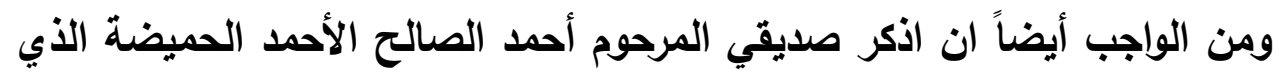

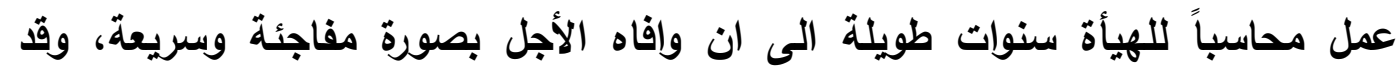
جمعتني بالمرحومين الصداقة الحميمية وزمالة العمل) . كان صالح الحميضة رحمه الله بشهادة زملائه، رجلاً اميناً نزيهاً في عمله بصئه وليانة المباني التي أمضى فيها ما يقرب من نصف قرن، اذ بدأ مع اول حفريات في الحضر عام (1901 (م)،

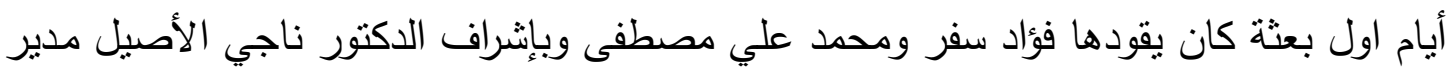

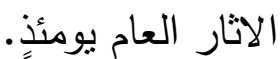

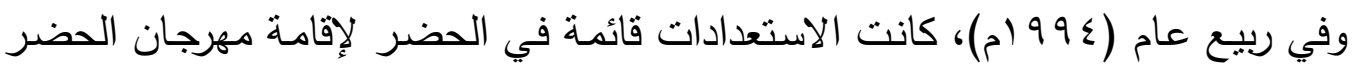

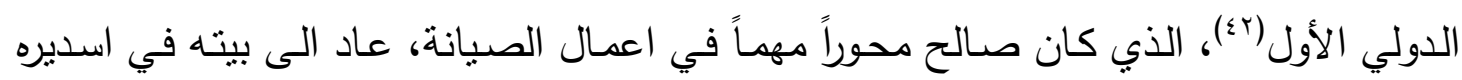
بقضاء الثرقاط، أصابته نوبة قلبية حادة، حينما كان بعد امتعته للعودة الى الحضر ليواصل التصل

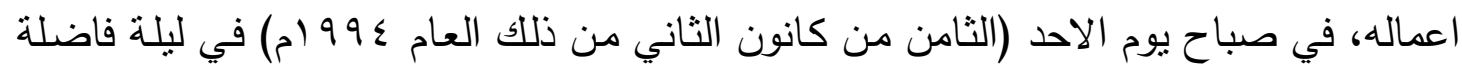
كريمة هي أسراء المصطفى محمد صلى الله عليه وسلم ومعراجهُ، فترك في نفس اسرته وقريته

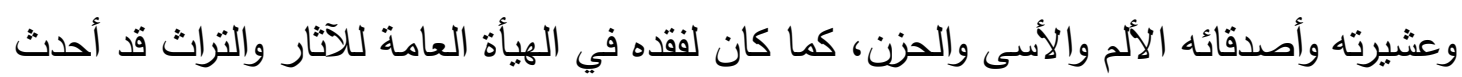
فراغاً واسعاً في هيأتها العاملة في الحضر لم بحل مكانه أحد حتى يومنا هذا، متلما فقدت هذه والها

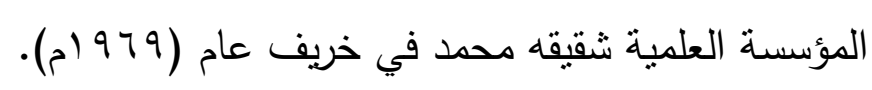

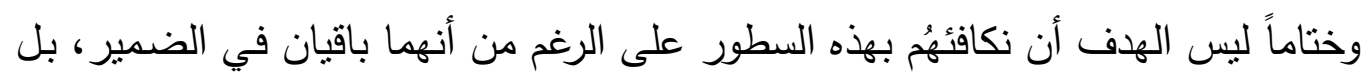

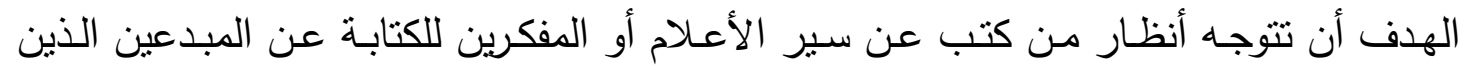

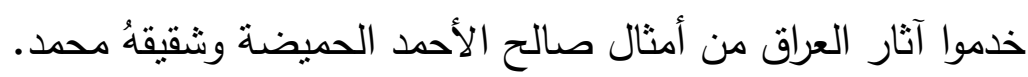
المصادر التي ذكرت صالح ومحمد رحمهما الله:

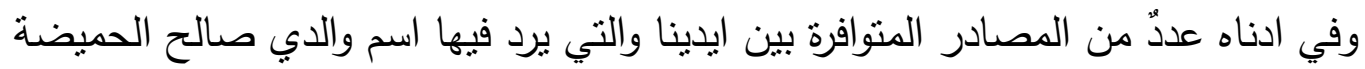

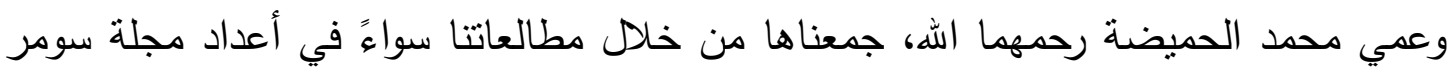

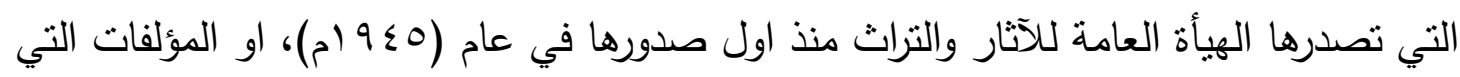

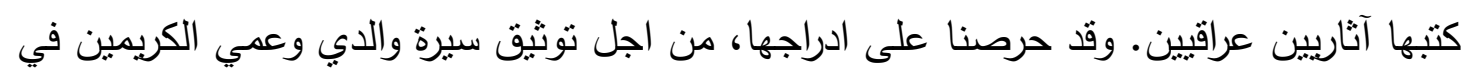

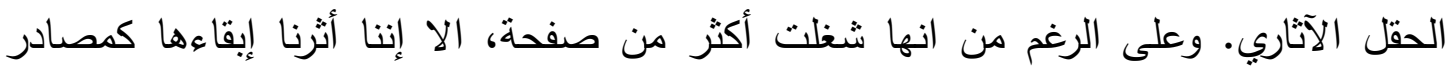

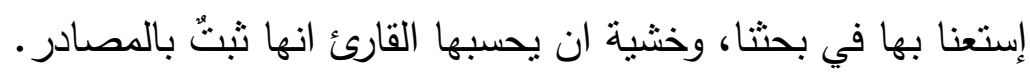




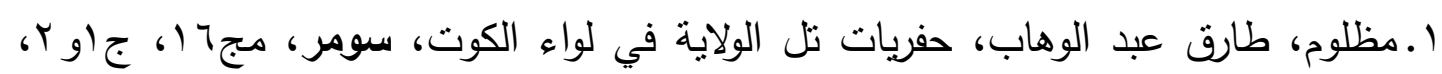

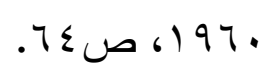

r. الجنابي، كاظم، حفريات تل شاملو في سهل شهرزور، سومر، مجلا، جاو ب، (197)،

$$
\text { صن صن }
$$

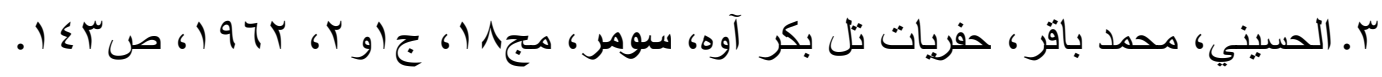

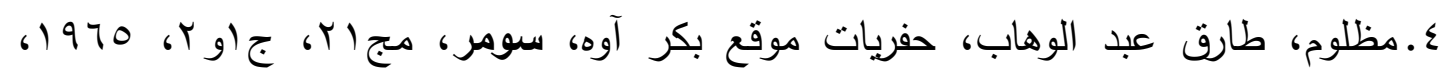

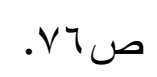

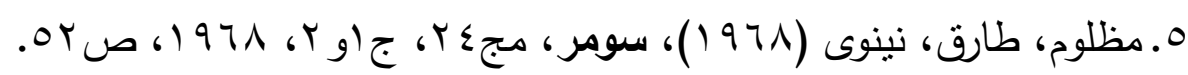

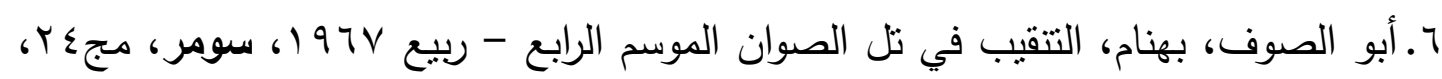

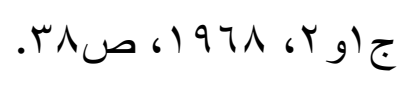

V.أبو الصوف، بهنام، مواطن الاثار في حوض دوكان والتتقبب في تل باسموسيان الموسم

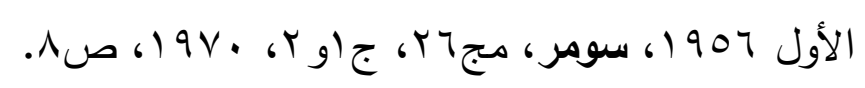

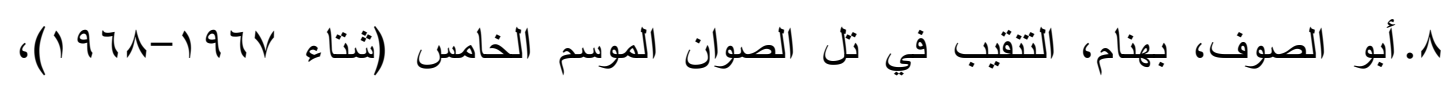

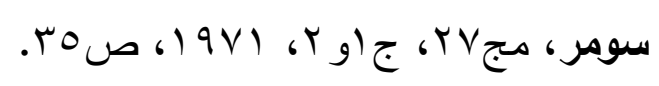

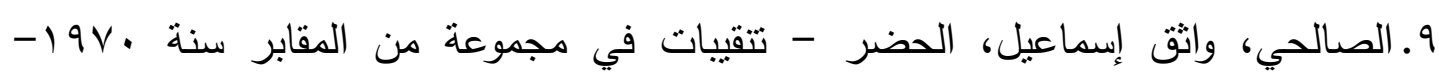

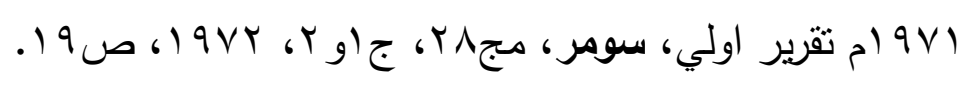

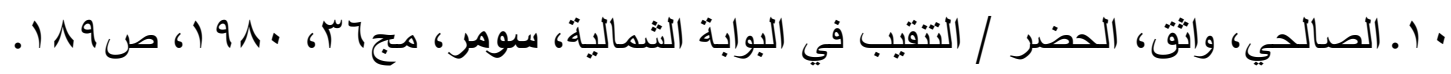

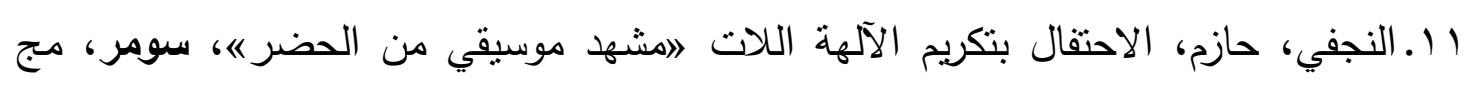

$$
\text { (r) }
$$

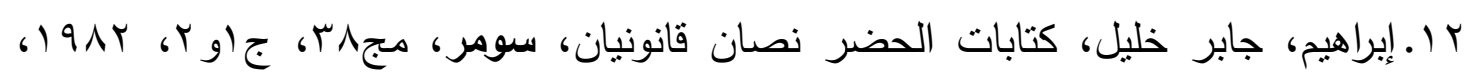

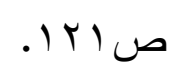

rا. عبدالله، محمد صبحي، تتقيبات المعبد الثاني عشر (معبد الاله نبو) في مدينة الحضر

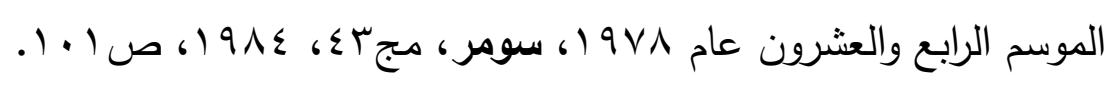

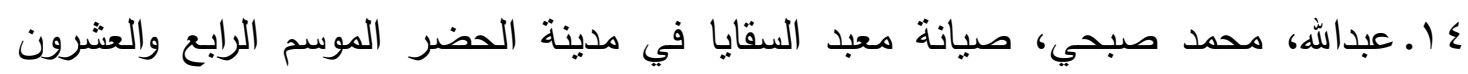
19V9-19VA

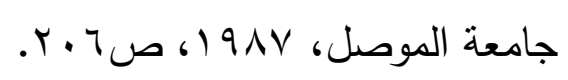

1. السعدون، حمد سلطان، تطور أسلوب النحت الحضري، رسالة ماجسنير (غير منشورة)، كلية الفنون الجميلة، جامعة بغداد، 911 1، التوطئة. 


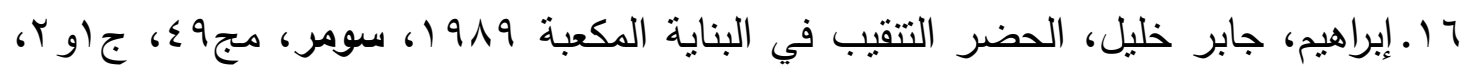
.rt.

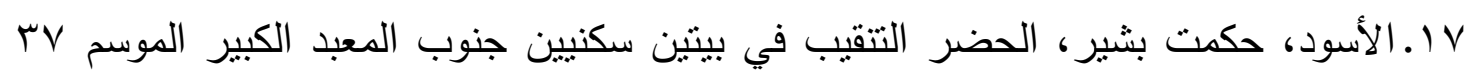

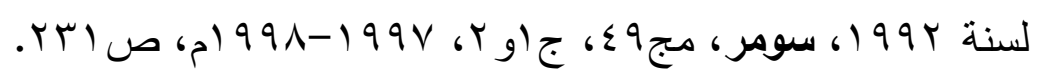

1 ا إبراهيم، جابر خليل، كتابات غير منشورة من البوابة الثرقية لسور الحضر، سومر، مج مجه،

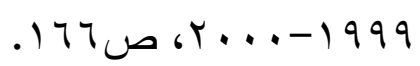

9 ا ـالأسود، حكمت بشير، الحضر / التنقيب في معبد الربة نناي ب9911، سومر، مج،0،

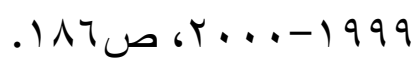

• ץ. إبراهيم، جابر خليل، كتابات غير منشورة من معبد نناي في الحضر، سومر، مج)،

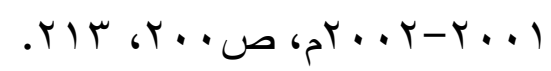

اץ.الأسود، حكمت بشير، دليل اثار الحضر، صدر لمناسبة انعقاد مهرجان الحضر الدولي

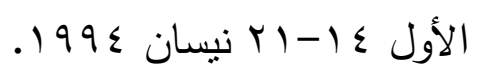

r. أبو الصوف، بهنام، عامل في الآثار: صار مساحاً ومهندساً وباحثاً ومخططاته مرجعاً

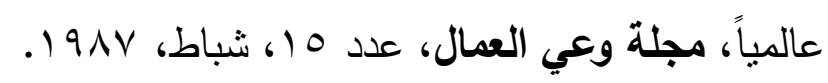

بr.أبو الصوف، بهنام، التاريخ من باطن الأرض آثار وحضارات واعمال ميدانية، عمان،

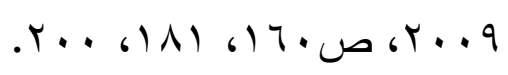

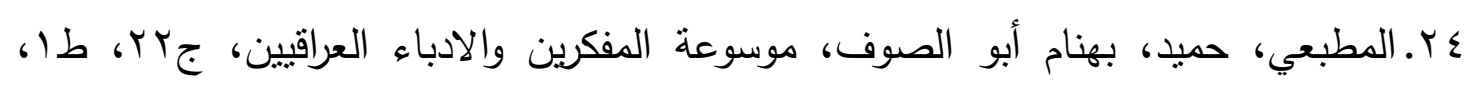

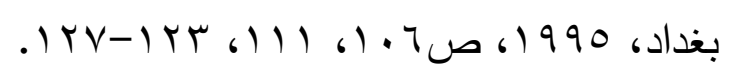

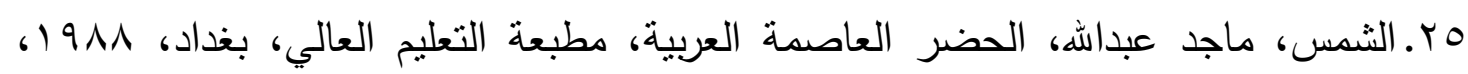

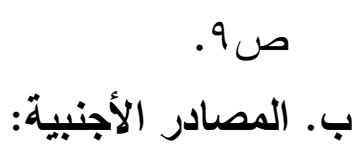

1. Abu al-Soof, Behnam, Tell Es-Sawwan Excavation of the Fourth Season (Spring, 1967), Sumer, Vol. XXIV, Nos. 1-2, 1968, P.4.

2. Yasin, Walid, Excavation at tell es-Sawwan, 1969 Report on The Sixth Seasons Excavations, Sumer, Vol. XXVI, Nos. 1-2, 1970, P.3.

3. Abu al-Soof, Behnam, Mounds in the Rania Plain and Excavations at Tell Basmusian (1956), Sumer, Vol. XXVI, Nos. 1-2, 1970, P. 68.

4. Abu Al-soof, Behnam, Tell Es-Sawwan Fifth Seasons Excavations (Winter 1967-1968), Sumer, Vol. XXVII, Nos. 1-2, 1971, P. 3.

5. Al-Salihi, Wathiq, HATRA Excavations in Group of Tombs 19701971 Preliminary Report, Sumer, Vol. XXVIII, Nos. 1-2, 1972, P.17.

6. Ibrahim. J. Kh, Pre-Islamic settlement in Jazirah, Mosul, 1986, P.14. 
صالح الأحمد الحميضة وشقيقةُ محمد خدما المسيرة الاثارية في العراق
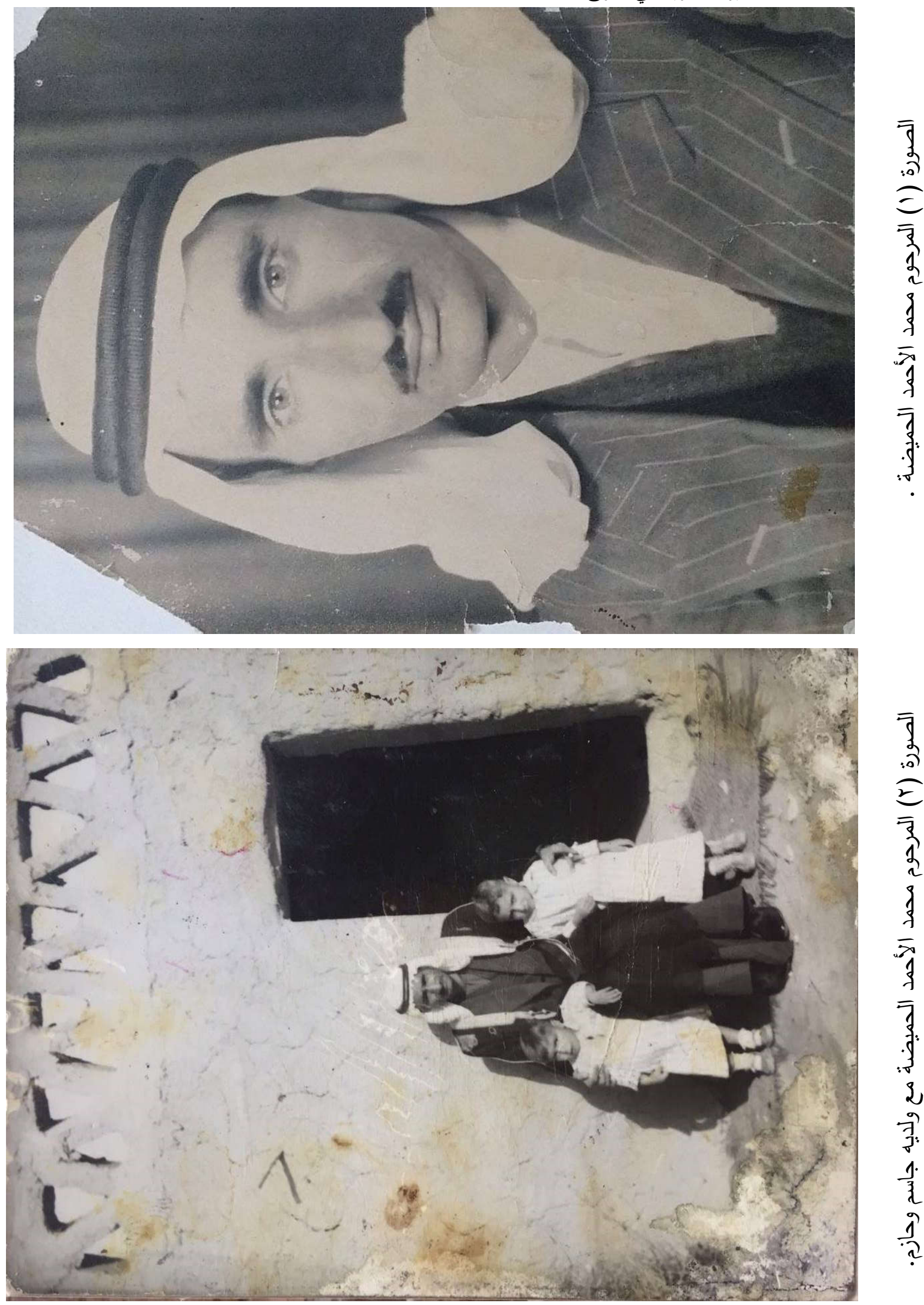

201 


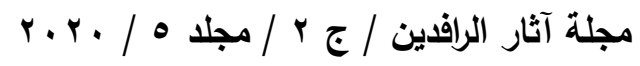

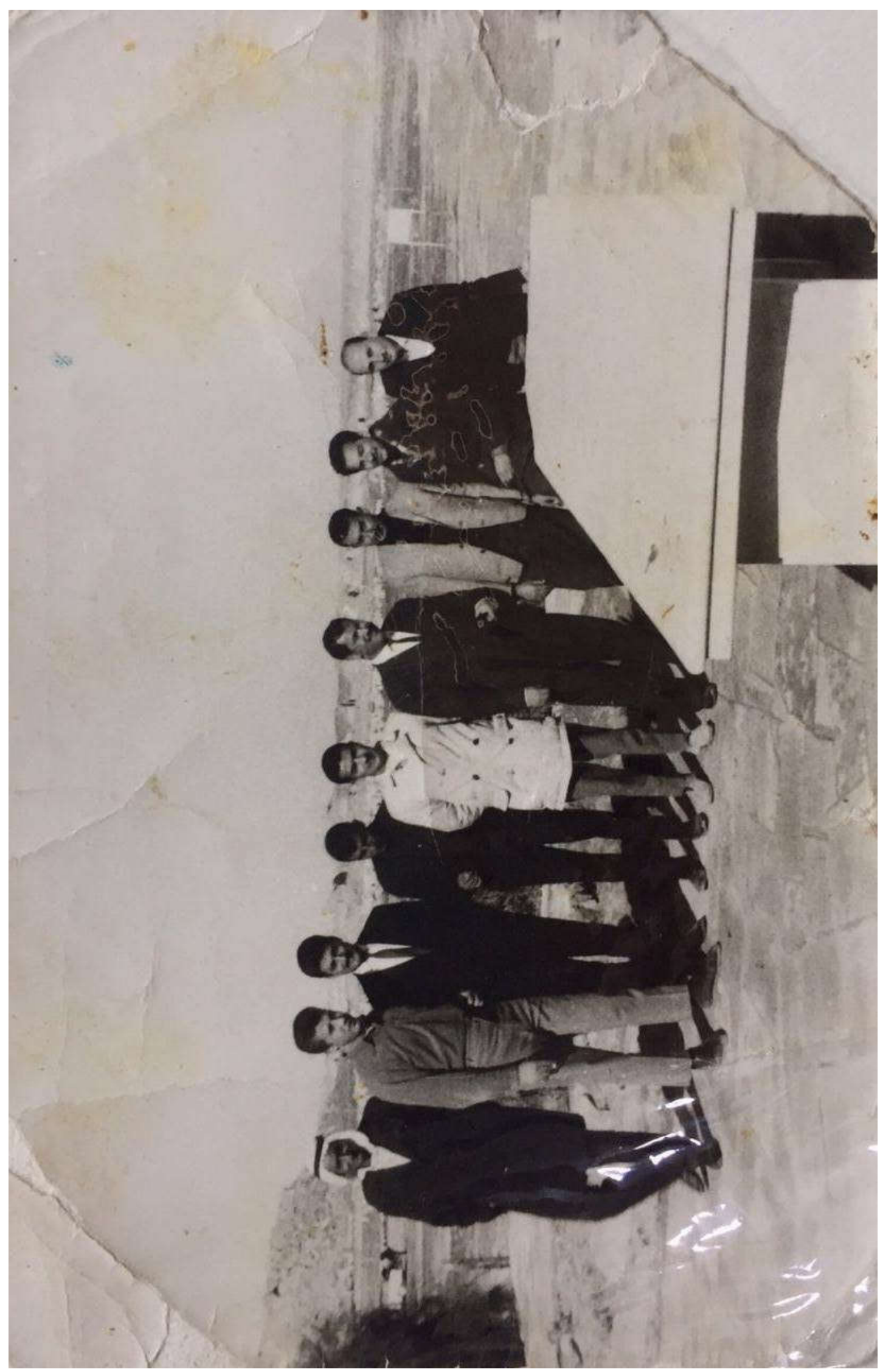

الصورة (r) المرحوم محمد الأحمد الحميضة مع ثلة من الآثاريين وهو في النهاية اليسرى من الصورة. 


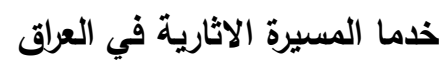

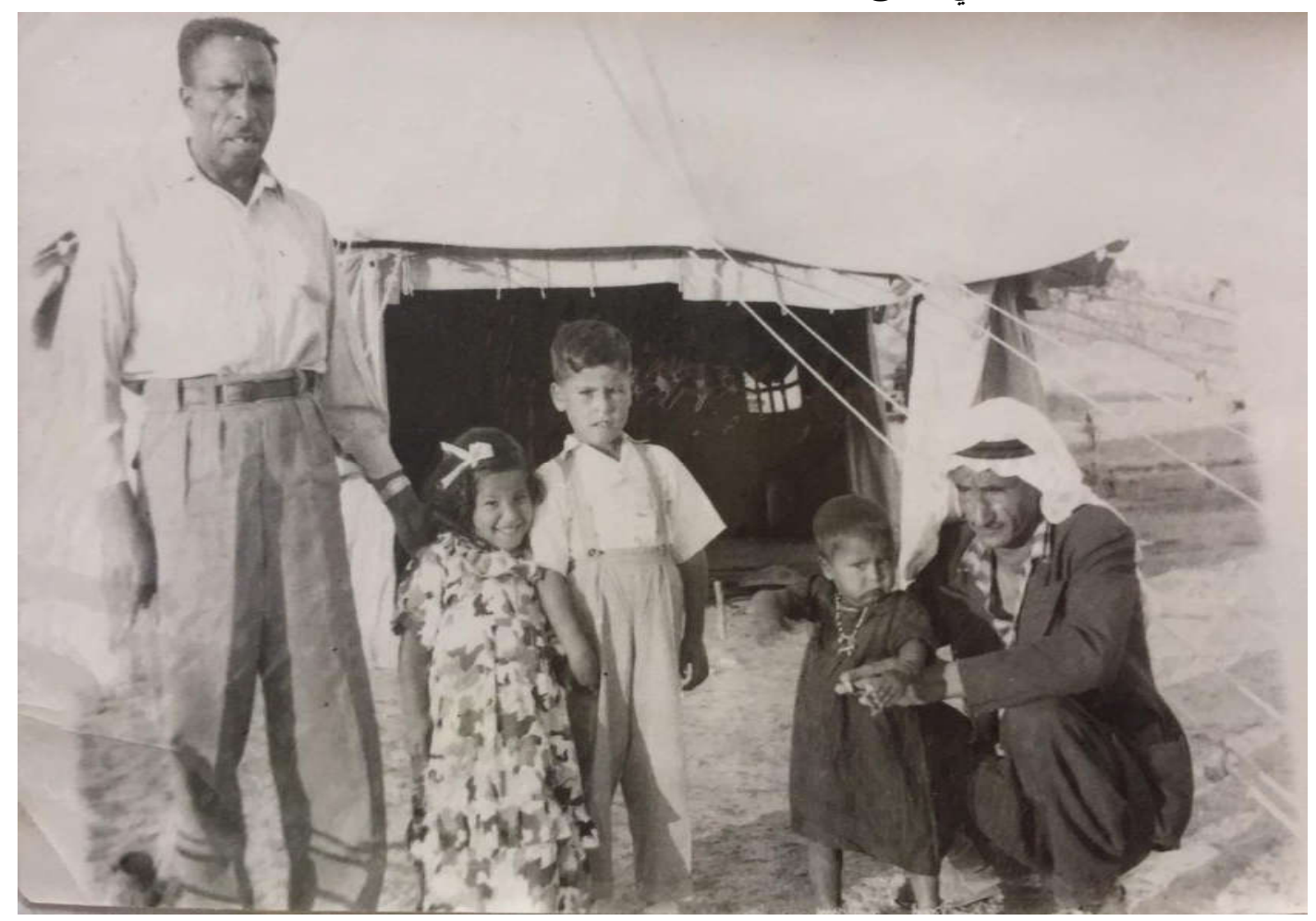

الصورة (ع) المرحوم محمد الأحمد الحميضة مع المنقب الثرقاطي الفذ عيسى الطعمة وأولاده.

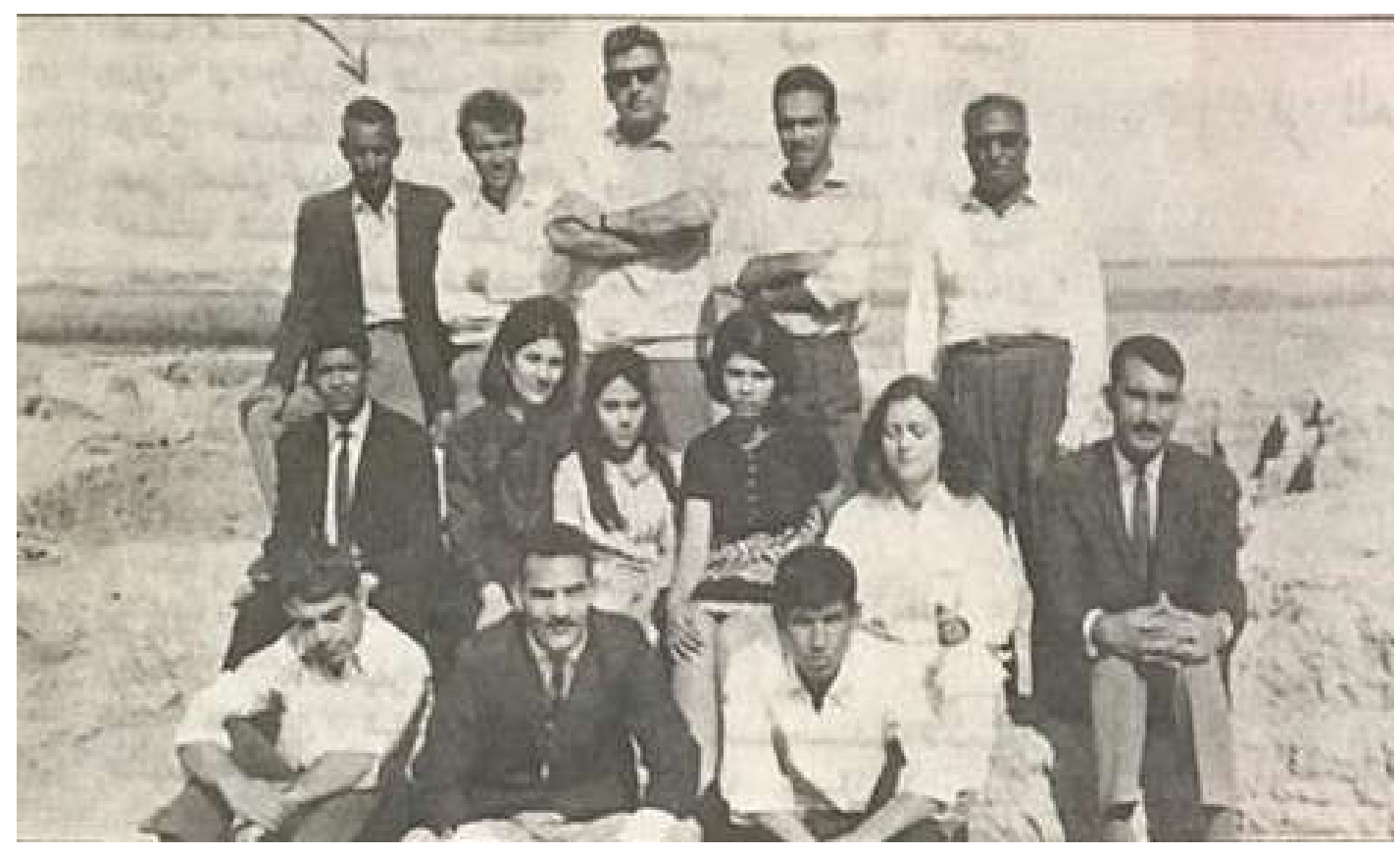

الصورة (0) المرحوم محمد الأحمد الحميضة (اقصى اليسار ) مع أعضاء بعثة التتقيب في تل

• الصوان (قرب سامراء) وطلبة الآثار 


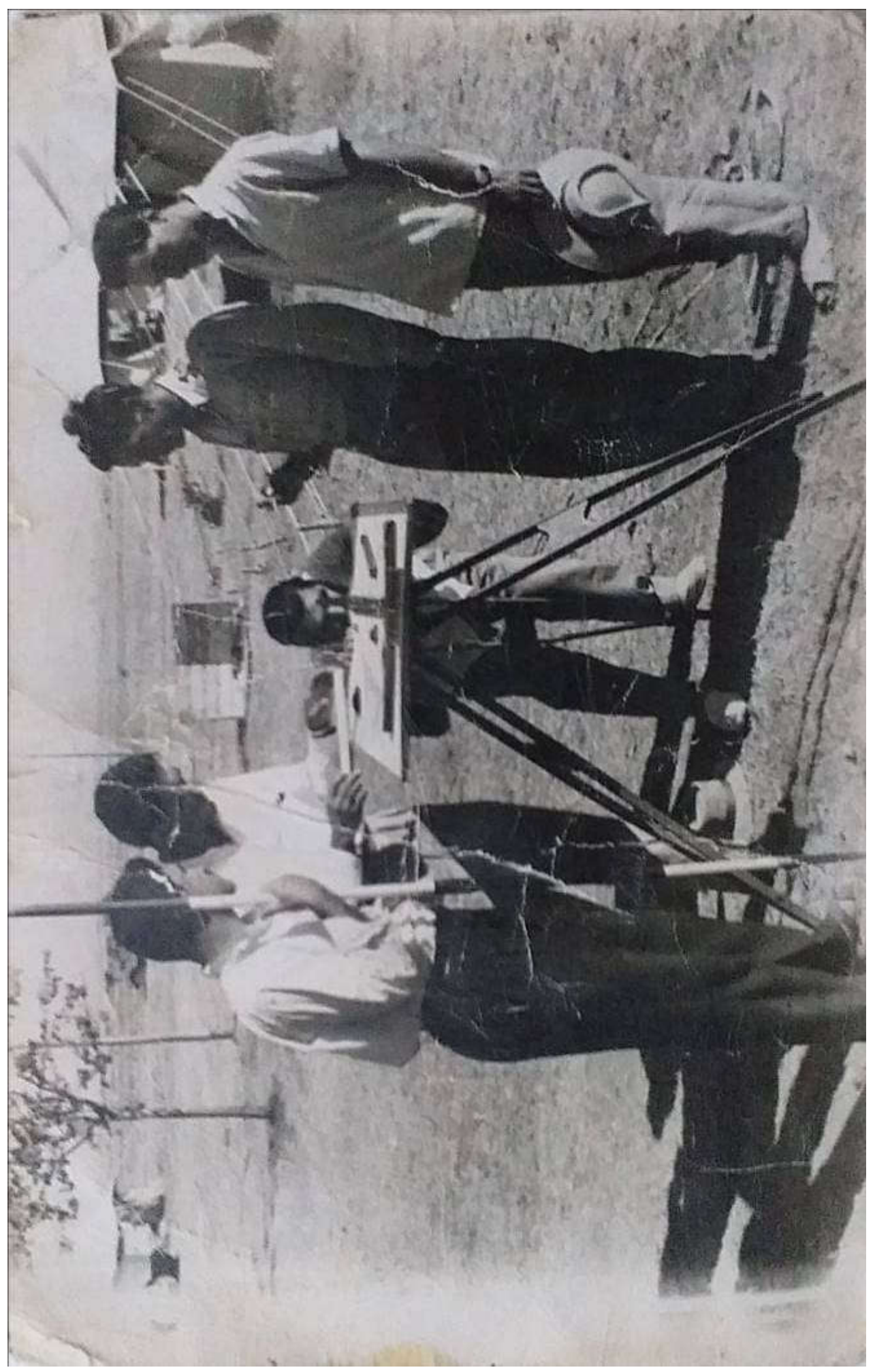

الصورة (7) المرحوم محمد الأحمد الحميضة مع طلاب من الدورة الثالثة في قسم الاثار ، والذين

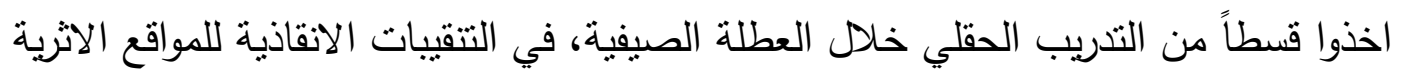

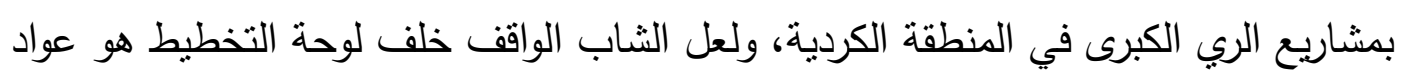

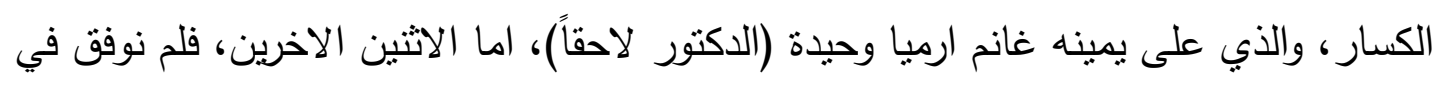
تتخيصهما، بسبب قدم الصورة وصغر حجمها وعدم وضوح ملامح الثباب الاربعة. 

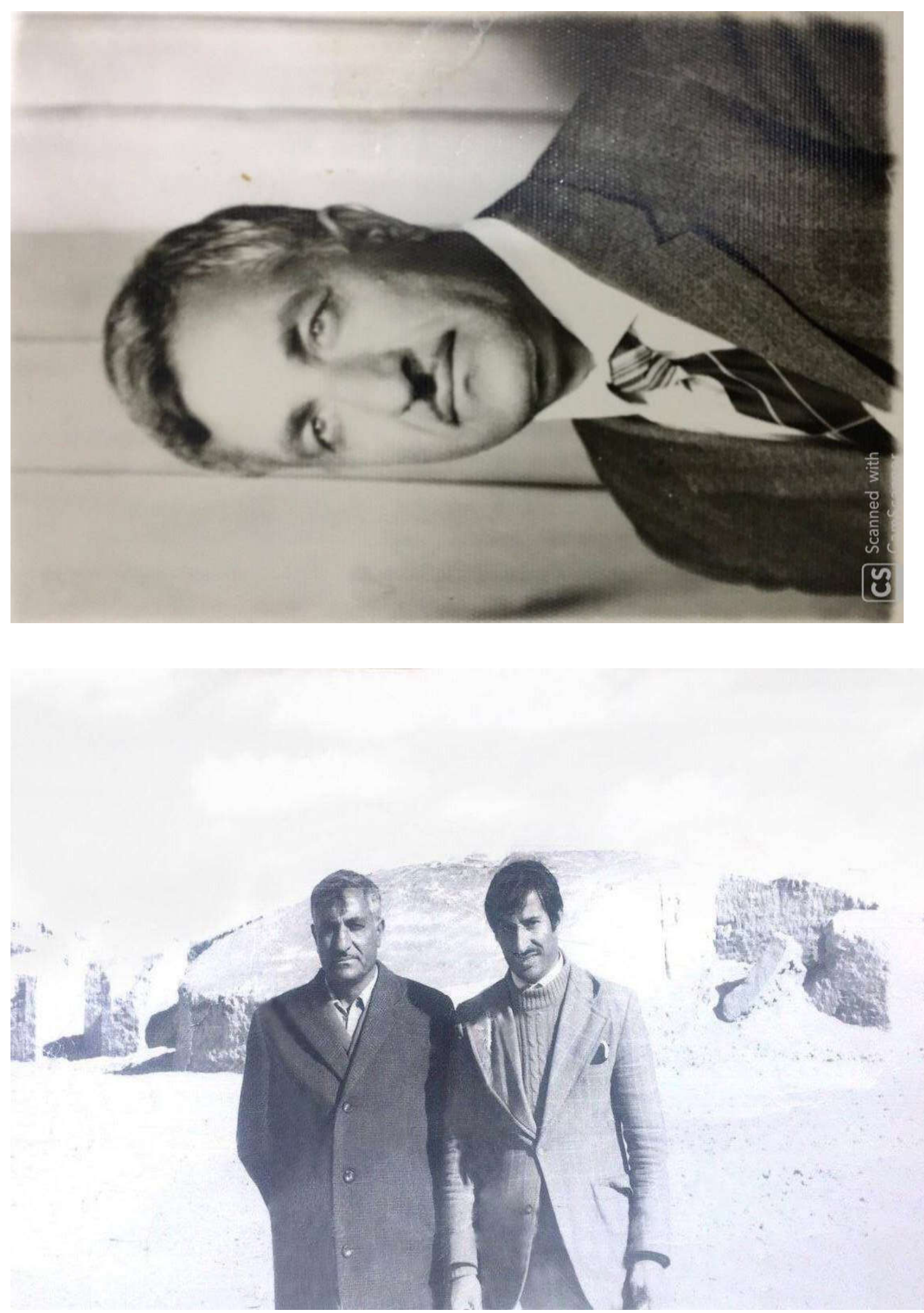

الصورة (^) المرحوم صالح الأحمد الحميضة مع الأستاذ الدكتور جابر خليل إبراهيم اثتاء تتقيباتهم 


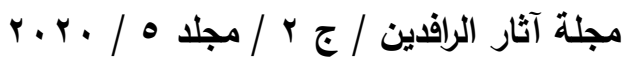

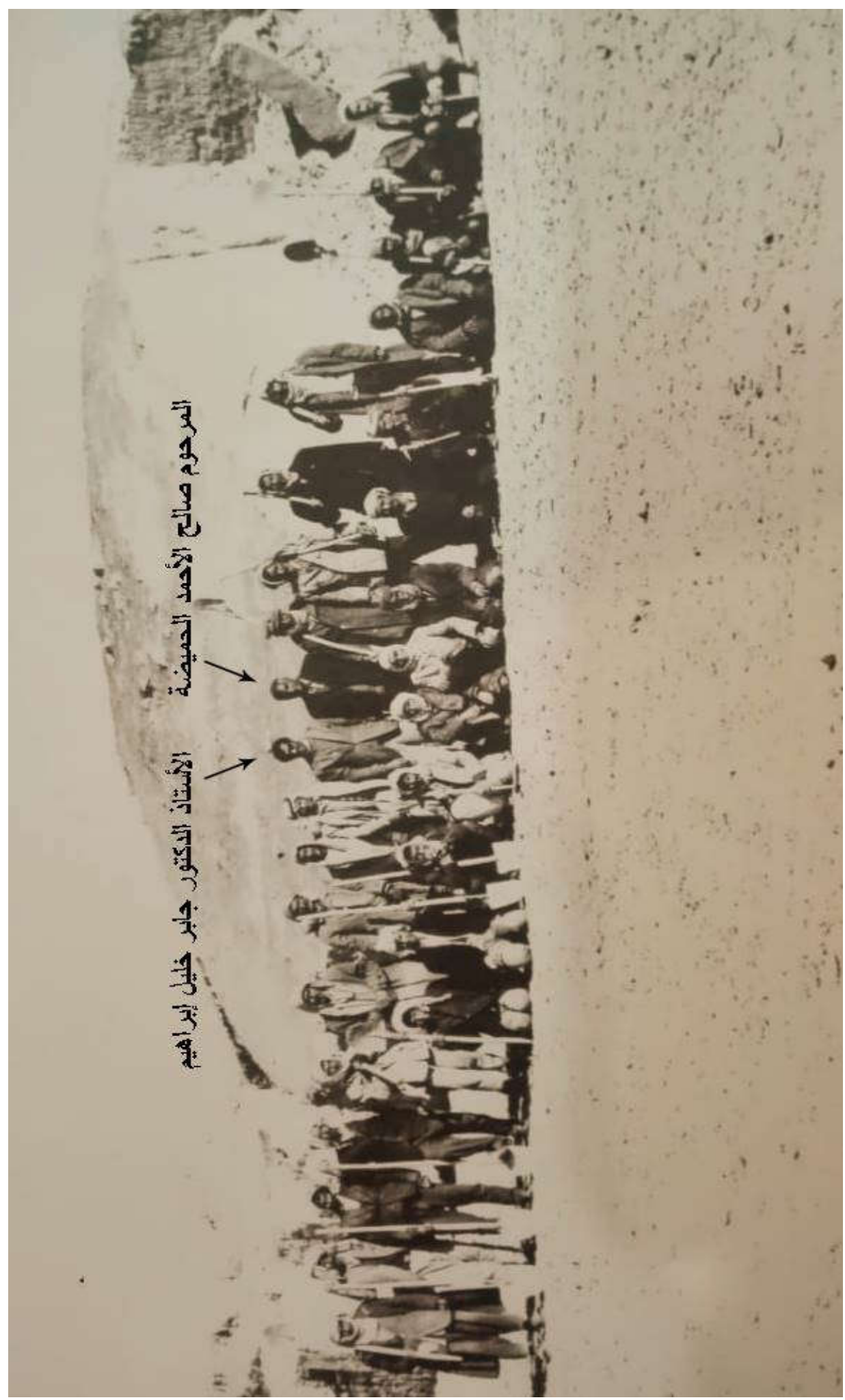

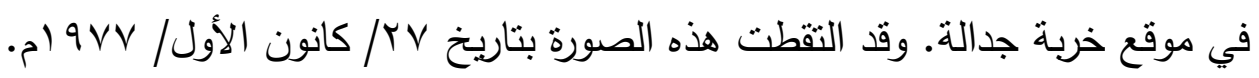
صورة رقم (9) المرحوم صالح الأحمد الحميضة مع الأستاذ الدكتور جابر خليل إبراهيم، ومجموعة من الاسطوات والشغيلة، اثتاء تتقيباتهم في موقع خربة جدالة. وقد التقطت هذه الصورة في نهاية الموسم الثاني، اواخر شهر آذار من العام 9 أم. 
خدما المسيرة الاثارية في العرلق

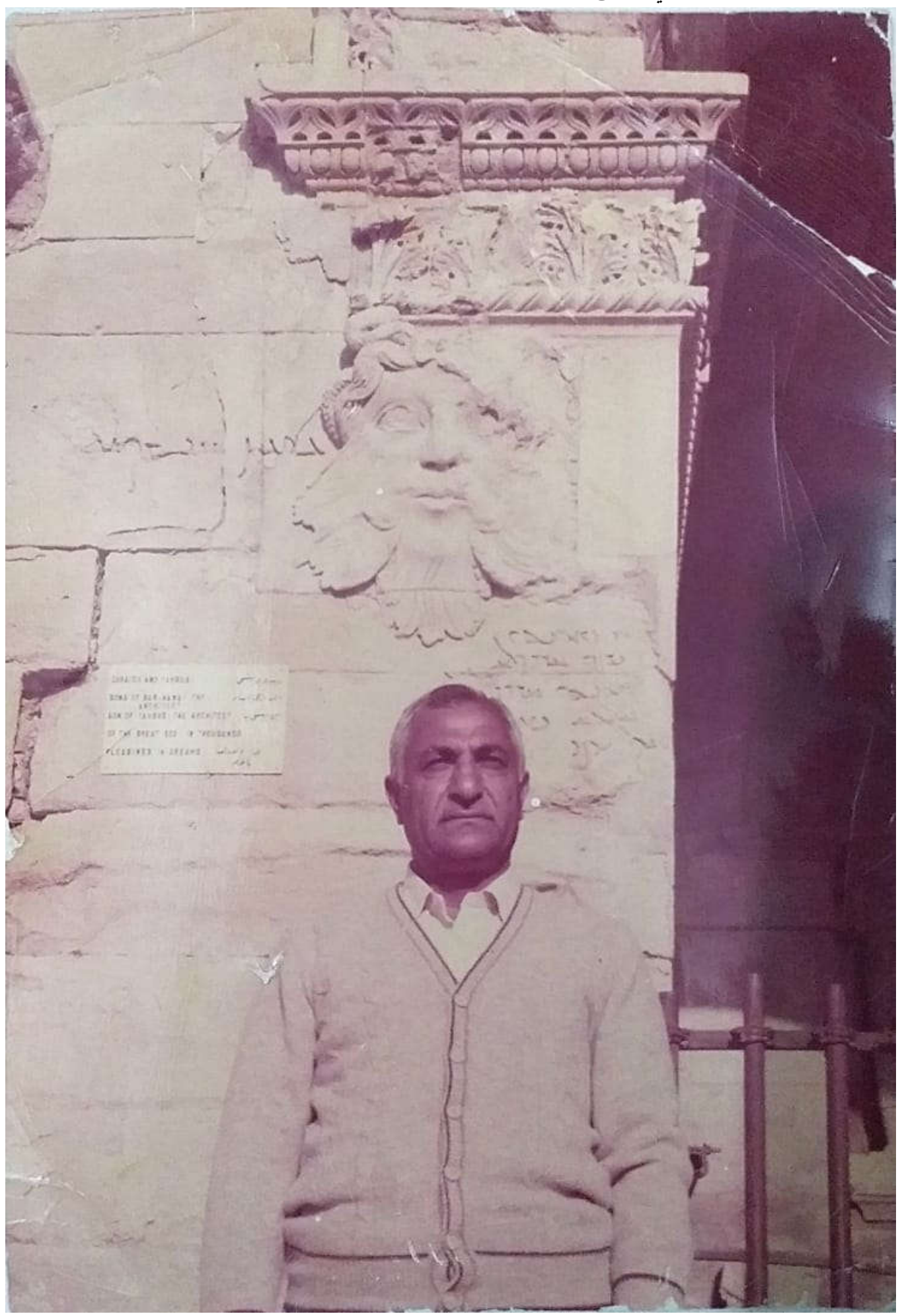

صورة رقم (• () المرحوم صالح الأحمد الحميضة، وخلفية الصورة هي واجهة الايوان الجنوبي من مجموعة الاواوين المتسقة في مدينة الحضر وفوق راسه نحت بارز لمشهر يمثل وجه رجل فوق راسه افعى، واسفلها كتابة آرامية، تخص الثفاء. ولعل هذه الصورة التذكارية قد التقطت

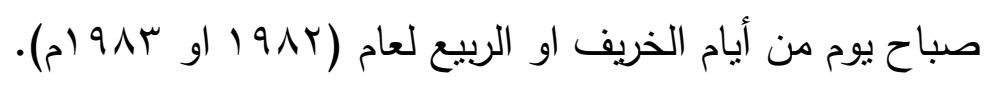




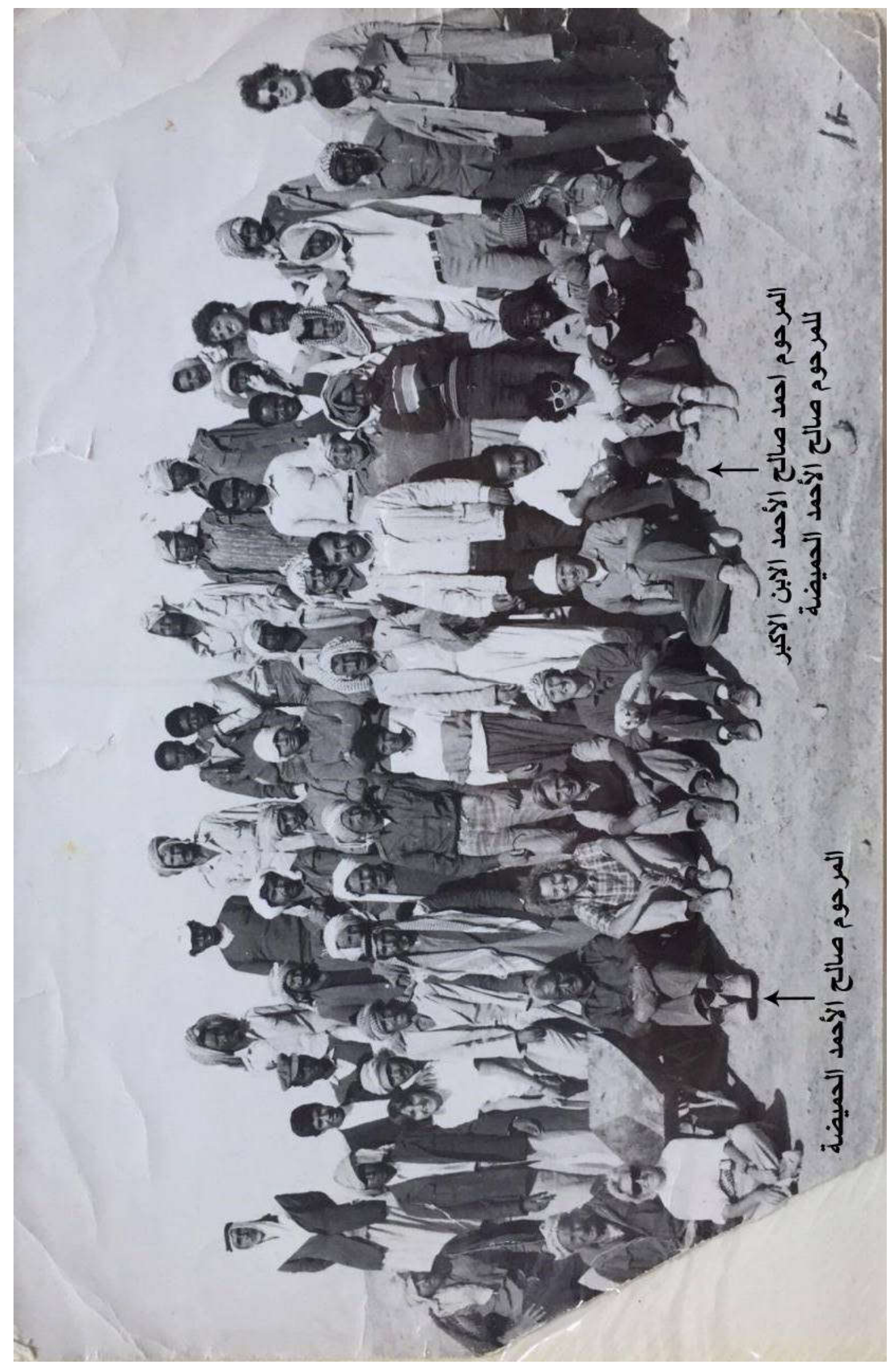

صورة رقم (1) المرحوم صالح الأحمد الحميضة وولده الاكبر المرحوم أحمد ومجموعة من

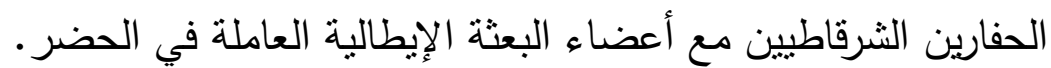


خدما المسيرة الاثارية في العرلق

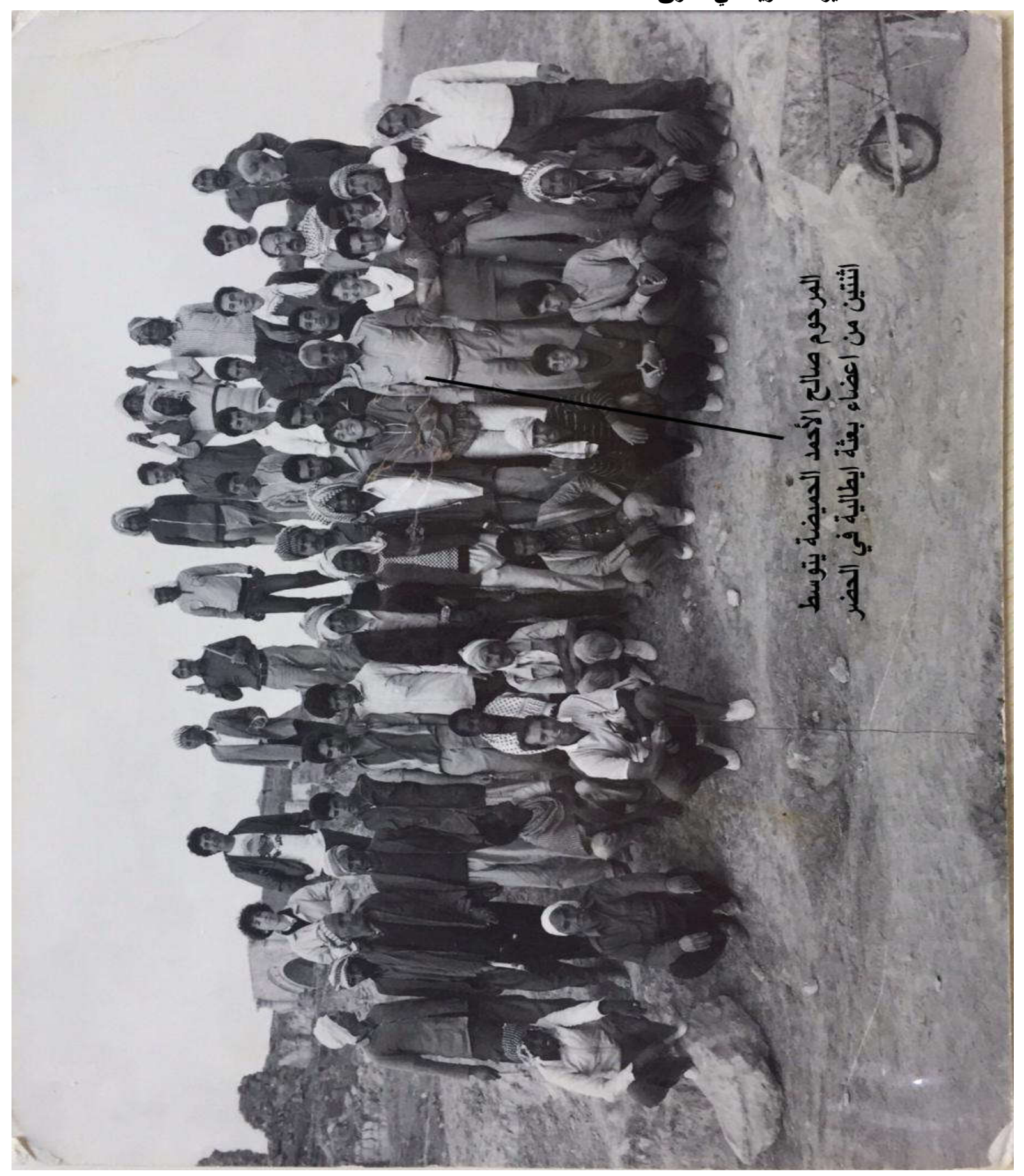

صورة رقم (Y () المرحوم صالح الأحمد الحميضة ومجموعة من الحفارين الثرقاطيين مع أعضاء البعثة الإيطالية العاملة في الحضر . 
(1) اود ان ابين ان هذه الفقرة هي مقتبسة من بحث غير منشور القي في ندوة عن الراحلين اقامتها كلية الاثار

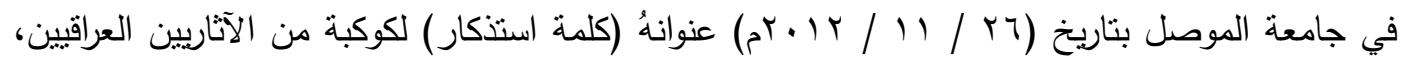

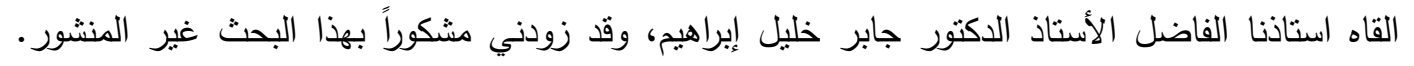

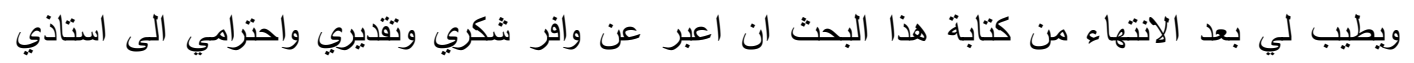

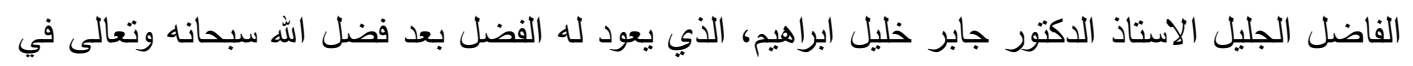

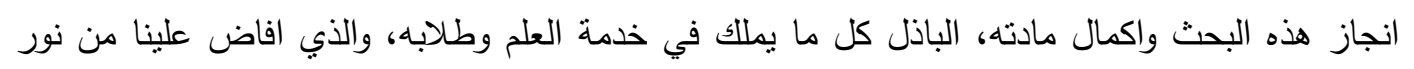

$$
\begin{aligned}
& \text { علمه فكان وسيبقى نعم الاب الناصح ونعم المعلم. }
\end{aligned}
$$

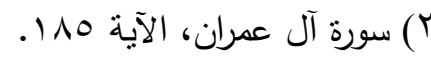

(r) نسبة الى بلدة الثرقاط الواقعة الى الجنوب من مدينة الموصل بنحو مئة كيلومتر ، والحفارين الوارد ذكرهم في هذا البحث، يعود نسبهم الى فذذ الرملي من عثيرة الجبور، الساكنين على امتداد شرق نهر دجلة لهنة والمعروفة باسم منطقة اسديره.

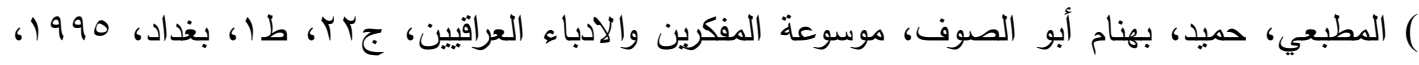

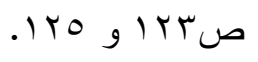

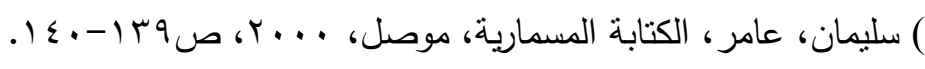

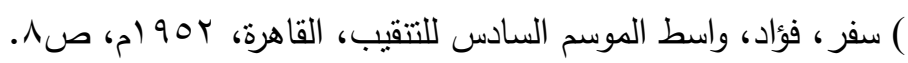

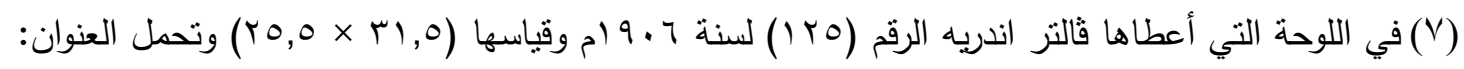
عمال شرقاطيون في حالة تهيئوهم لعبور نهر دجلة سباحة، للوصول الى مقر عملهم في قلعة شرقاط (آشور) •. وهي باللغة الألمانية.

(^) مشروع المسيب الكبير (1900-1901) (1) المشرف العام: محمد علي مصطفى، والأعضاء العاملون: بهنام أبو الصوف وطارق مظلوم وعبد القادر حسن التكريتي وخالد الاعظمي وعادل ناجي وكامل حسين علي

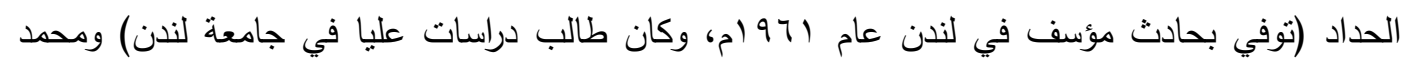

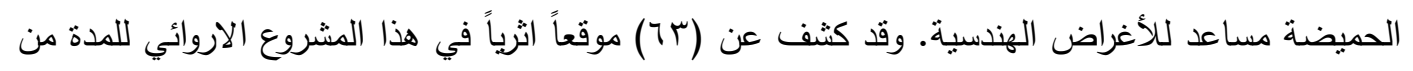
(9 حزيران 900 (م) الى (ب ب آب 901 (م)، ونهر المسيب هو فرع من الفرات ينتظم في سدة الهندية.

Al-Haik, Albert, R, Key Lists of Archaeological Excavations in Iraq 1842-1965, Florida, 1968, PP. 50-51.

(9) أبو الصوف، بهنام، "عامل في الآثار : صار مساحاً ومهندساً وباحثاً ومخططاته مرجعاً عالمياً،، مجلة وعي

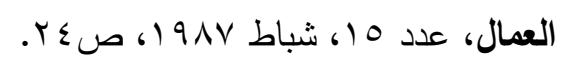

(• (1) يقع الموقع المعروف محلياً باسم تل الصوان على الضفة الثرقية لنهر دجلة، على بعد حوالي الكم

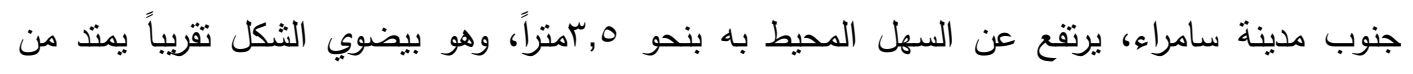

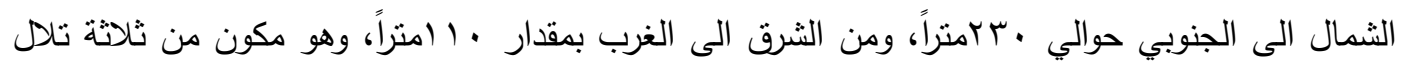
يشار اليها على التوالي (A, B, C) . للمزيد ينظر: El-Wailly, Faisal, and, Abu es-soof, Behnam, The Excavations at Tell Es-sawwan first Preliminary Report (1964),

Sumer, Vol. XXI, No. 1-2, 1965, P.17. 


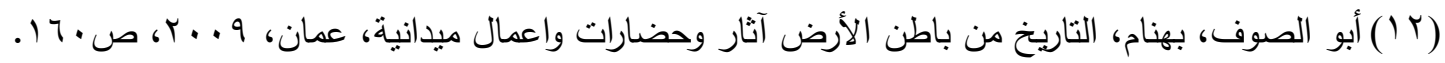

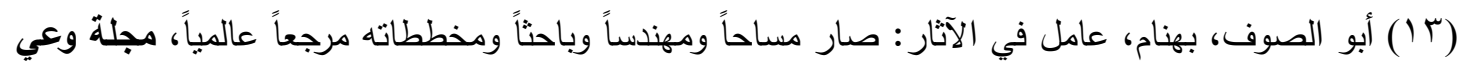
العمال، مصدر سابق، صه ب. وينظر أيضاً: المطبعي، حميد، بهنام أبو الصوف، موسوعة المفكرين

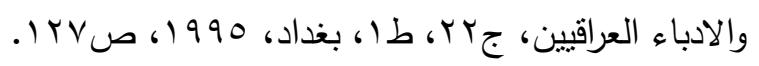

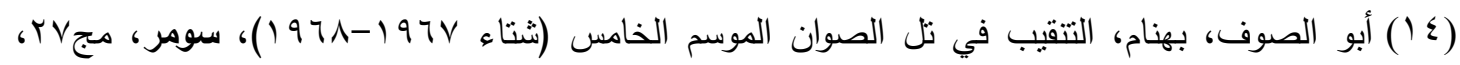

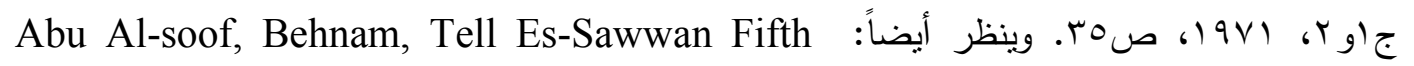
Seasons Excavations (Winter 1967-1968), Sumer, Vol. XXVII, Nos. 1-2, 1971, P.

(10) أبو الصوف، بهنام، عامل في الآثار : صار مساحاً ومهندساً وباحثاً ومخططاته مرجعاً عالمياً، مجلة وعي

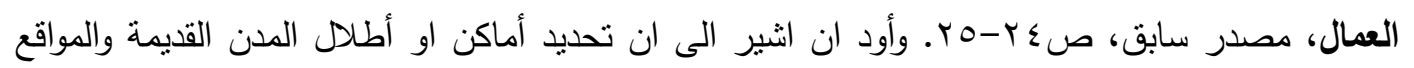
الاثرية الواردة في هذه الفقرة هي من تعليقات الباحث.

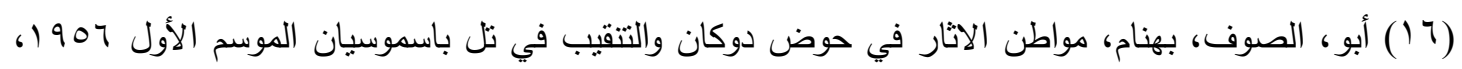

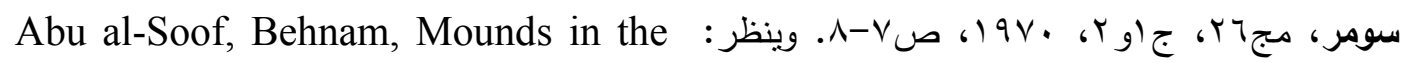
Rania Plain and Excavations at Tell Basmusian (1956), Sumer, Vol. XXVI, Nos. 1-2, 1970, P. 68.

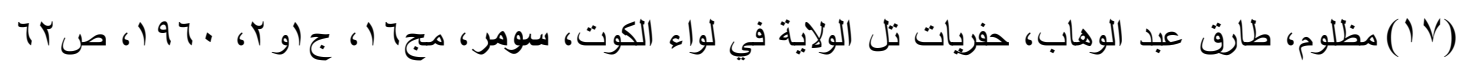
و

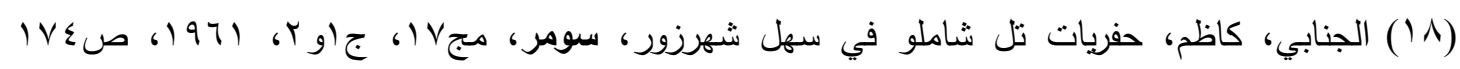
$.1 \times 49$

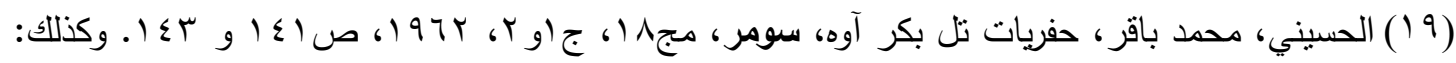

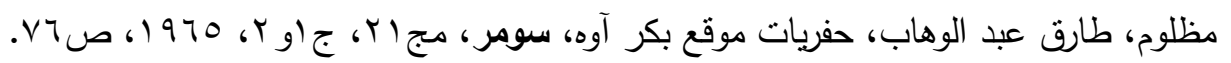

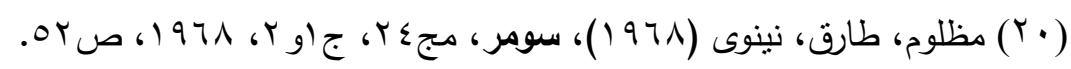

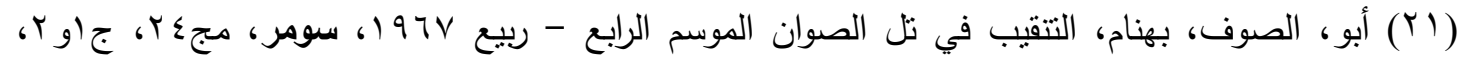

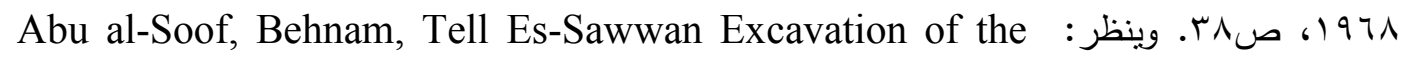
Fourth Season (Spring, 1967), Sumer, Vol. XXIV, Nos. 1-2, 1968, P.4.

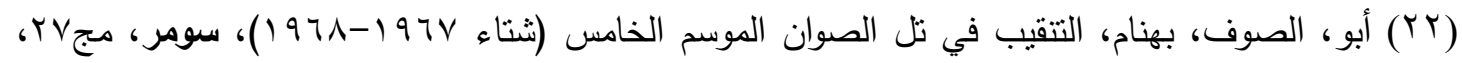

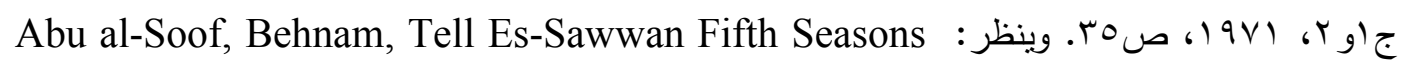
Excavations (Winter 1967-1968), Sumer, Vol. XXVII, Nos. 1-2, 1971, P. 3. (23) Yasin, Walid, Excavation at tell es-Sawwan, 1969 Report on The Sixth Seasons Excavations, Sumer, Vol. XXVI, Nos. 1-2, 1970, P. 3.

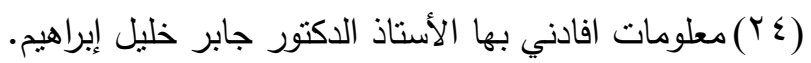

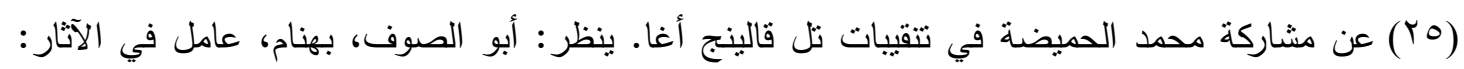

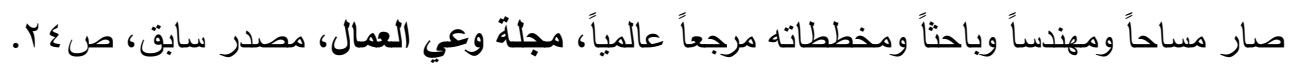


(T؟Y أبو الصوف، بهنام، عامل في الآثار : صار مساحاً ومهندساً وباحثاً ومخططاته مرجعاً عالمياً، مجلة وعي

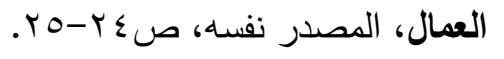

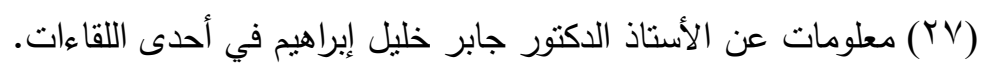
(YA)

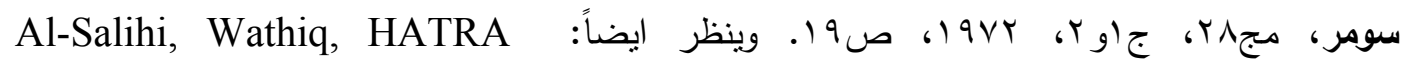
Excavations in Group of Tombs 1970-1971 Preliminary Report, Sumer, Vol. XXVIII, Nos. 1-2, 1972, P. 17.

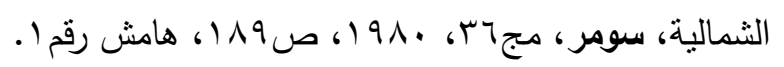

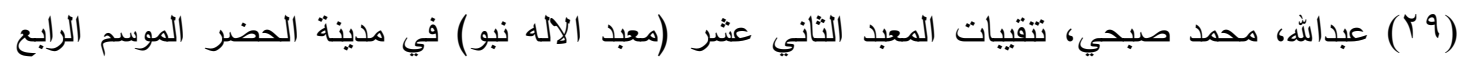

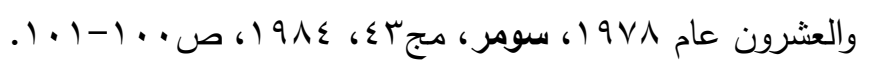

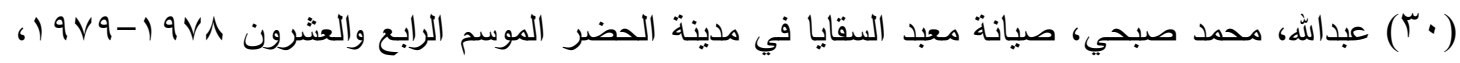

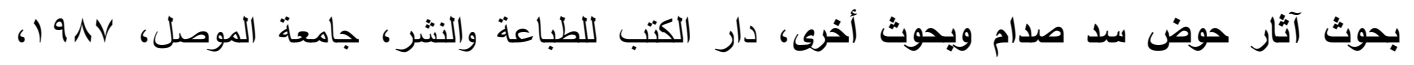

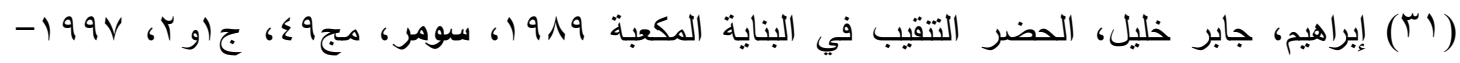

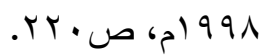

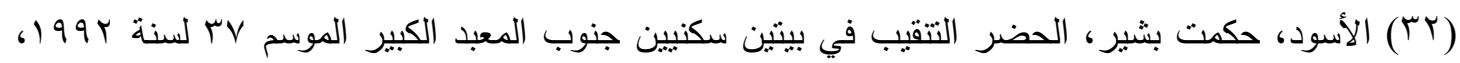

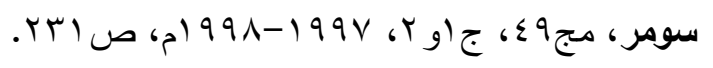

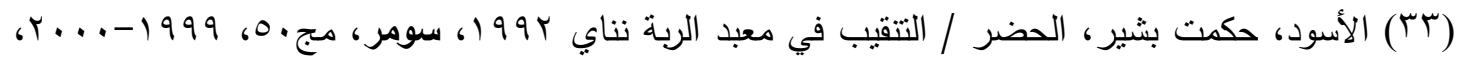

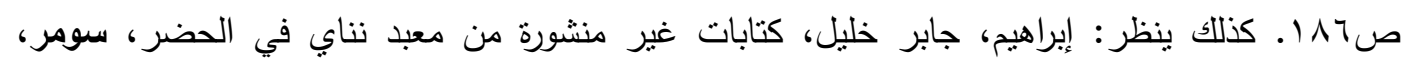

$$
\text { مج) }
$$

(34) Ibrahim. J. Kh, Pre-Islamic settlement in Jazirah, Mosul, 1986, P.14.

(ro) كلمة كتبها استاذي الجليل الأستاذ الدكتور جابر خليل إبراهيم على نسخة من اطروحته، اهداني إياها

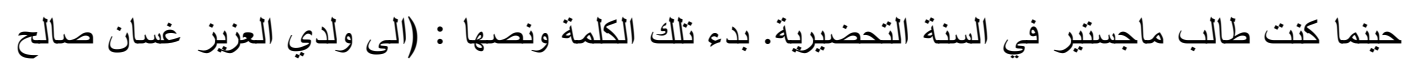

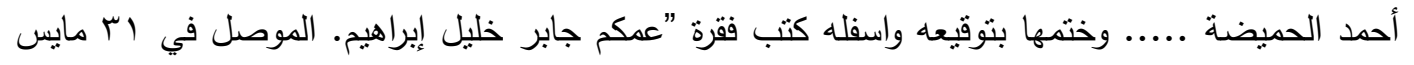
(ا • r'"). وهذه الهدية كانت وما نزال وستبقى هي الهدية الاثمن والاغلى في حياتي ولها معزة في قلبي ومكانة خاصة في مكتبتي الثخصية. (ד廿) عن قلعة البنت وقلعة (قصر ) الجبار • راجع: الحميضة، غسان صالح أحمد، مواطن الآثار في حوض دجلة بين شمالي آشور ومنطقة الفتحة في ضوء المسوحات والتنقيبات الأثرية، رسالة ماجستير (غير

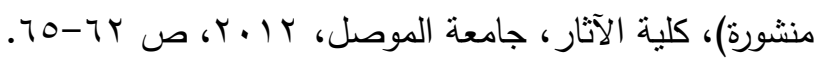

$$
\text { (rv) نشرت المعلومات والصور التي جمعت من تلك الرحلنين في المرجع: }
$$

Ibrahim. J. Kh, Pre-Islamic settlement in Jazirah, Mosul, 1986, PP. 56-57. and, Pls. 27-29, 30-34.

(^^) عن الخرائط والصور التي التقطها الرحالين فردريك زاره وارنست هرتسفلد عن قلعة البنت وقلعة (قصر)

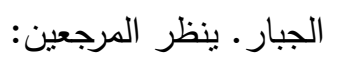


Herzfeld, F, Untersuchungen über die historische Topographie der Landschaft am Tigris, kleinen Zàb und Ğebel Hamrin, Memnon, Erster Band, Leipzig, 1907. PP. 102-111. Sذلك ينظر Sarre. F, und, Herzfeld. E, Archäologische Reise im Euphrat- und Tigris- Gebiet, Band. I, Berlin, 1911, PP. 214-218.

(\%) هذه المعلومات كان قد حدثي عنها الاستاذ الدكتور جابر خليل إبراهيم في لقاءات سابقة عديدة في جامعة

الموصل في مكتبه في كلية الاثار وفي بيته وكان الحديث عن والدي المرحوم صالح الحميضة المحور الرئيس لتلك اللقاءات.

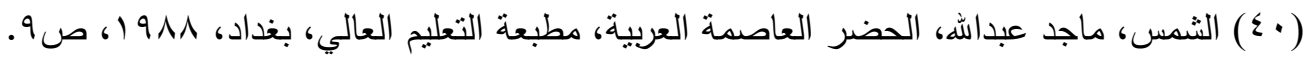

(إ) السعدون، حمد سلطان، تطور أسلوب النحت الحضري، رسالة ماجستير (غير منشورة)، كلية الفنون الجميلة، جامعة بغداد، 911 1، التوطئة.

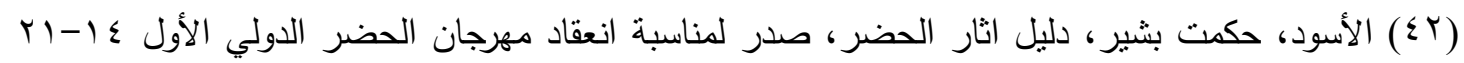




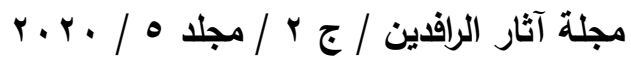



Contents

\begin{tabular}{|c|c|c|}
\hline Page & Research Name & Subject \\
\hline \multicolumn{3}{|c|}{ Arabic Part: } \\
\hline 1 & Prof. Khalid Salim Ismael & Preface \\
\hline $3-6$ & Prof.Dr. Jabber Khalil Ibraheem & $\begin{array}{l}\text { Mourning Mr. Yosif Thannoon } \\
(1931-2020)\end{array}$ \\
\hline $7-16$ & $\begin{array}{l}\text { Prof. Khalid Salim Ismael } \\
\text { Osama Mohammed Khorsheed }\end{array}$ & $\begin{array}{l}\text { Akkadian Formulas in a New } \\
\text { Cuneiform Text from Ur III Period } \\
\text { Kept in the Iraqi Museum }\end{array}$ \\
\hline $17-38$ & PProf.Dr. Nawala A. Al-Mutawalli & $\begin{array}{l}\text { Epilepsy in the Cuneiform Sources in } \\
\text { Mesopotamia }\end{array}$ \\
\hline $39-60$ & $\begin{array}{l}\text { Prof. Dr. Khalaf fares al.tarwenh } \\
\text { Assis. Prof. Dr. Zidan Rasheed } \\
\text { Assis.Lecturer. Yadgar Muhammed } \\
\text { Saleem } \\
\end{array}$ & Qishla Mazne (A Field Study) \\
\hline 61-94 & Dr. Abdullah Khorsheed Qadir & $\begin{array}{l}\text { Structural Elements of Heritage } \\
\text { Architecture in Iraq }\end{array}$ \\
\hline $95-112$ & $\begin{array}{l}\text { Assis. Prof. Dr. Ari Kh. Kamil } \\
\text { Rashed D. Jendi }\end{array}$ & $\begin{array}{l}\text { Unpublished Cuneiform Texts from Ur } \\
\text { III Period (2112-2004 B.C) in } \\
\text { Sulaimaniya Museum }\end{array}$ \\
\hline $113-130$ & Assist.Prof.Othman Ghanim Mohammed & $\begin{array}{l}\text { The Adverbial Suffix } \backslash-\text { iš } \backslash \\
\text { In Ancient Iraqi Languages And its } \\
\text { Impacts } \\
\text { On Modern Iraqi Dialects }\end{array}$ \\
\hline $131-154$ & Lec.Dr. Wafaa Hadi Zwaid & $\begin{array}{l}\text { Unpublished Cuneiform Texts from Ur } \\
\text { III Period about Animals }\end{array}$ \\
\hline $155-184$ & Lec. Dr.,Haitham Qasim Mohammad & $\begin{array}{l}\text { Inscriptions of Mosul Mosques } \\
\text { Mihrabs during Ottoman Period: A } \\
\text { study of selected samples }\end{array}$ \\
\hline $185-202$ & Lecturer. Ghassan Mardan Haji & $\begin{array}{l}\text { Animals on the Scenes of the Modern } \\
\text { Sumerian Arts }\end{array}$ \\
\hline $203-236$ & Lecturer. Ghassan Salih Al-Hamedha & $\begin{array}{l}\text { From the Sharqati excavators : } \\
\text { Salih Ahmed Al-Hamedha and his } \\
\text { brother Mohammad } \\
\text { Served the Archeological Excavations } \\
\text { in Iraq }\end{array}$ \\
\hline \multicolumn{3}{|c|}{ English Part: } \\
\hline $3-20$ & Muhammad Hamagharib Muhammad & $\begin{array}{l}\text { Remote Sensing in Archaeology: A } \\
\text { Brief Review }\end{array}$ \\
\hline
\end{tabular}


12- The original research papers submitted to the magazine are not returned to their owners, whether published or not.

13- Tables and figures are numbered in a row according to their appearance in the research, provided with titles, submitted with separate papers, blueprints are submitted in black ink and images to be in high resolution.

14- The marginal numbers are written in parentheses and are presented in series at the end of the research.

15- The full source name is indicated in the margin, with the abbreviated source in parentheses at the end of the margin.

16- The researcher is responsible for correcting the linguistic and typographical errors in his research.

17- The magazine operates according to self-funding. Therefore, the researcher bears the publication fees of $(100,000)$ one hundred thousand Iraqi dinars.

18- Each researcher shall be provided with one copy of his research. As for the full copy of the journal, it is requested from the magazine's secretariat and a price is determined by the Editorial Board.

19- The papers should be sent to the journal e-mail:

uom.atharalrafedain@gmail.com 


\section{Publishing rules in Athar Al-Rafedain Journal (AARJ):}

1- The journal accepts scientific research that falls in specializations:

- Ancient Archaeology and Islamic Archaeology .

- Ancient languages with their dialects and comparative studies.

- Cuneiform Inscriptions and ancient lines.

- Historical and cultural studies

- Archaeological geology.

- Archaeological survey techniques.

- Anthropological studies.

- Conservation and restoration.

2- Research papers shall be submitted to the magazine in both Arabic and English.

3- The research shall be printed on (A4) paper, word-2010 system, with double spaces between lines, Simplified Arabic font for Arabic language, Times New Roman for English language, delivered on $\mathrm{CD}$, and in two paper based copies.

4- The title of the research should be printed in the middle of the page, followed by the name of the researcher, his academic degree, his full work address, and e-mail.

5- The research should contain an abstract in Arabic and English languages, it shouldn't exceed (100) words.

6- The abstract of the research in English contains the title of the research, the name of the researcher, his academic degree, his full workplace, and his e-mail.

7- The research must include keywords related to the title of the research and its content.

8- That the research was not previously published or was submitted to obtain a degree or is derived from the intellectual property of another researcher, and the researcher must undertake this in writing when submitting it for publication.

9- The researcher is obliged to follow the correct scientific foundations in his research.

10- The researcher is obligated to amend his research terms to suit the experts 'suggestions and the method of publishing in the journal.

11- The number of research pages does not exceed (25) pages, and in case of exceeding the required number, the researcher shall pay an additional amount for each additional page. 


\title{
Arabic Language Expert \\ Dr. Maan Yahya Mohammed
}

Dep. Of Arabic Language /College of Arts / University of Mosul

\author{
English Language Expert
}

Assist. Lect. Ammar Ahmed Mahmood

Dep. Of Translation Language / College of Arts / University of Mosul

Design Cover

Dr. Amer Al-Jumaili 


\title{
$\underline{\text { Editorial Board }}$
}

\author{
Prof. Khalid Salim Ismael \\ Editor-in-Chief
}

\section{Assist Prof. Hassanein Haydar Abdlwahed \\ Managing Editor}

\section{Members}

Prof. Elizabeth Stone

Prof. Adeileid Otto

Prof. Walther Sallaberger

Prof. Nicolo Marchetti

Prof. Hudeeb Hayawi Abdulkareem

Prof. Jawad Matar Almosawi

Prof. Rafah Jasim Hammadi

Prof. Abel Hashim Ali

Assist Prof. Yasamin Abdulkareem Mohammed Ali

Assist Prof. Vyan Muafak Rasheed

Assist Prof. Hani Abdulghani Abdullah 



\section{Journal}

\section{Athar Al-Rafedain}

Accredited Scientific Journal

It Search's in Archaeology of Iraq and Ancient Near East

Published by College of Archaeology - University of Mosul

E-Mail: uom.atharalrafedain@gmail.com

Vol.5 / No. 2

1442 A.H. / 2020 A.D. 


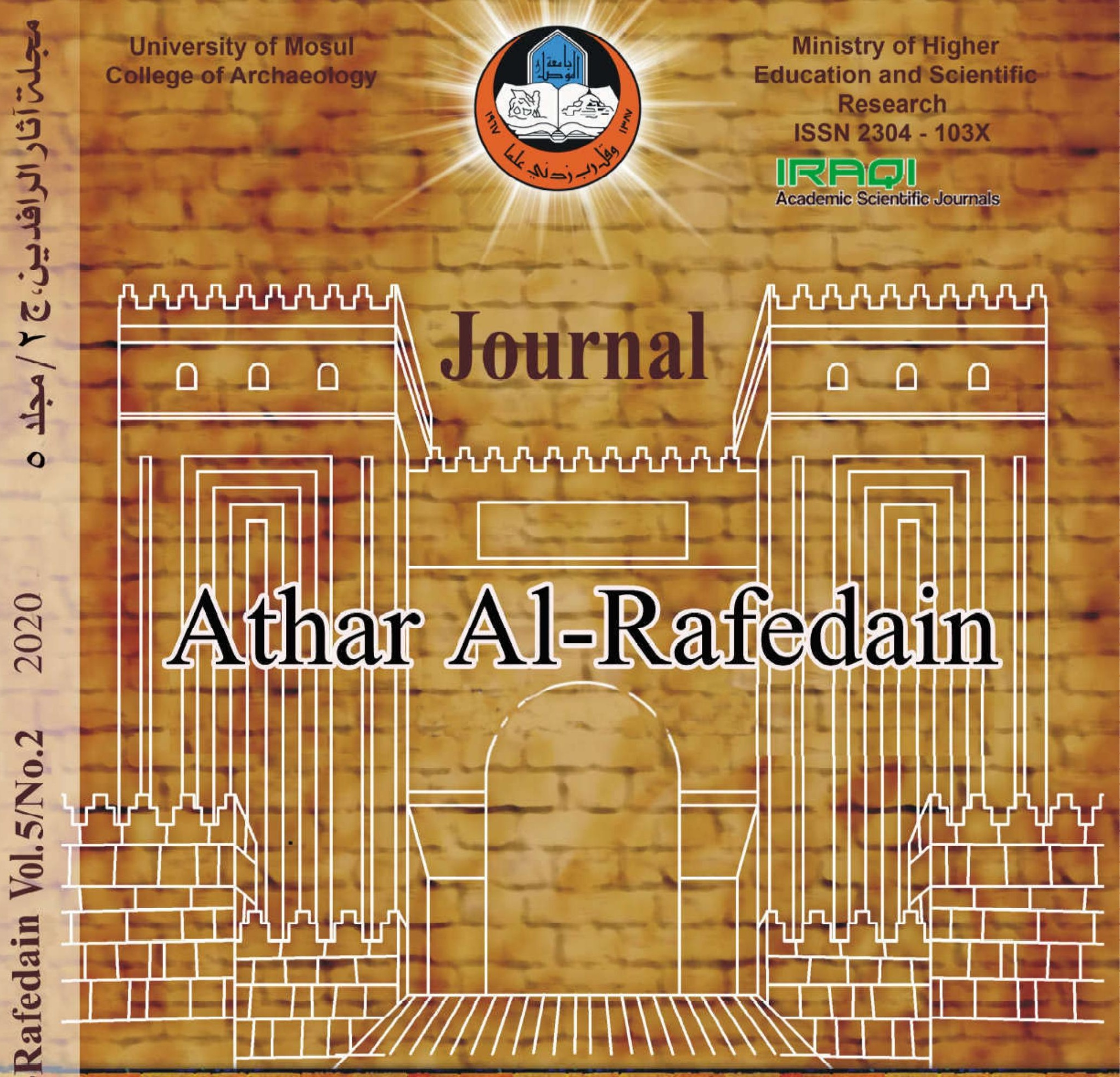

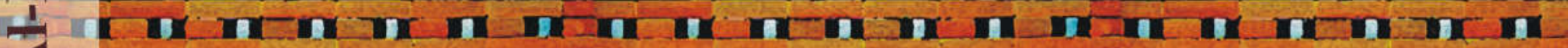

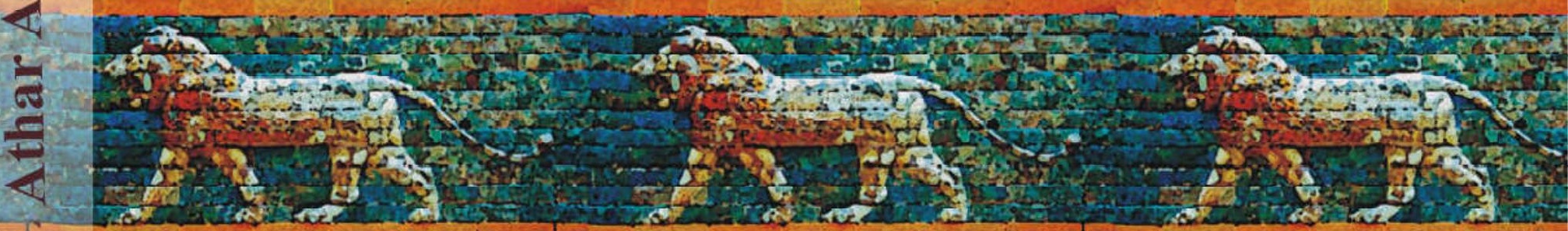

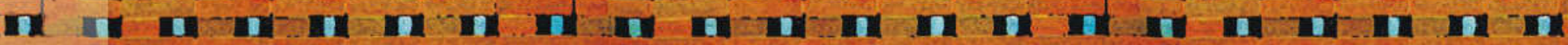

Accredited Scientific Journal It Search's in Archaeology of Iraq and Ancient Near East

Published College of Archaeology - University of Mosul / Vol.5/ No.2 / 1442 A.H. / 2020 A.D. 